Bulletin of the American Museum of Natural History

Anthropological Papers of the American MUSEUm of Natural History

Publications Committee

ROBERT S. VOSS, CHAIR

BOARD OF EDITORS

Jin Meng, Paleontology

LORENZO PRENDINI, INVERTEBRATE ZOOLOGY

ROBERT S. VOSS, VerTEBRATE ZOOLOG

PETER M. WHITELEY, ANTHROPOLOGY

MANAGING EDITOR

MARY KNIGHT

Submission procedures can be found at http://research.amnh.org/scipubs

All issues of Novitates and Bulletin are available on the web from http://digitallibrary.amnh.org/dspace

Order printed copies from http//www.amnhshopcom or via standard mail from: American Museum of Natural History_-Scientific Publications

Central Park West at 79th Street

New York, NY 10024

@ This paper meets the requirements of ANSI/NISO Z39.48-1992 (permanence of paper).

THE BRAZILIAN GOBLIN SPIDERS OF THE

NEW GENUS PREDATOROONOPS (ARANEAE: OONOPIDAE)

ANTONIO D. BRESCOVIT, ALEXANDRE B.

BONALDO, ADALBERTO J. SANTOS,

RICARDO OTT, AND CRISTINA A. RHEIMS

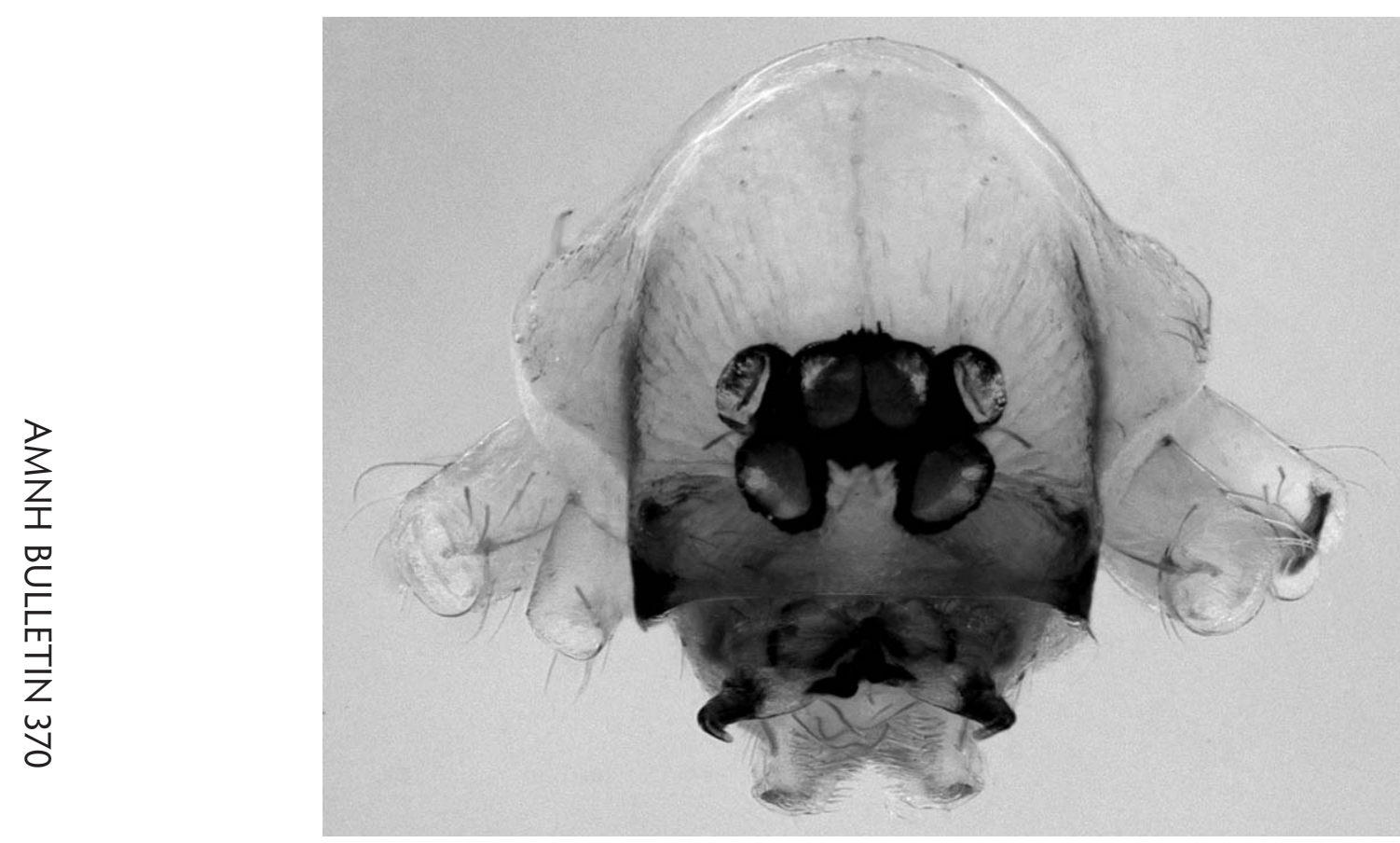

On the cover: Predatoroonops schwarzeneggeri, neW SPECIES, MALE, CARAPACE, FRONTAL VIEW. 


\title{
THE BRAZILIAN GOBLIN SPIDERS OF THE \\ NEW GENUS PREDATOROONOPS \\ (ARANEAE: OONOPIDAE)
}

\author{
ANTONIO D. BRESCOVIT \\ Instituto Butantan \\ Laboratório Especial de Coleções Zoológicas, \\ Av. Vital Brasil, 1500. São Paulo, SP, Brazil 05503-900 \\ ALEXANDRE B. BONALDO \\ Museu Paraense Emílio Goeldi, Coordenação de Zoologia, \\ Laboratório de Aracnologia, \\ Campus de Pesquisa, Avenida Perimetral, 1901. \\ Belém, PA, Brazil 66040-170 \\ ADALBERTO J. SANTOS \\ Universidade Federal de Minas Gerais, \\ Instituto de Ciências Biológicas, \\ Departamento de Zoologia. Av. Antonio Carlos, \\ 6627. Belo Horizonte, MG, Brazil 12270-901 \\ RICARDO OTT \\ Museu de Ciências Naturais, \\ Fundação Zoobotânica do Rio Grande do Sul. Rua \\ Dr. Salvador França, 1427. Porto Alegre, RS, \\ Brazil 90690-000

\section{CRISTINA A. RHEIMS} \\ Instituto Butantan \\ Laboratório Especial de Coleções Zoológicas, \\ Av. Vital Brasil, 1500. Sã̃ Paulo, SP, Brazil 05503-900 \\ BULLETIN OF THE AMERICAN MUSEUM OF NATURAL HISTORY \\ Number 370, 68 pp., 474 figures, 4 maps \\ Issued June 21, 2012
}




\begin{abstract}
The new endemic goblin spider genus Predatoroonops is erected for 17 new soft-bodied oonopid species from Brazil: Predatoroonops schwarzeneggeri, sp. nov., is the type species of the genus, $P$. poncho, sp. nov., $P$. billy, sp. nov., $P$. valverde, sp. nov., $P$. blain, sp. nov., $P$. maceliot, sp. nov., $P$. anna, sp. nov., $P$. rickhawkins, sp. nov., $P$. dutch, sp. nov., $P$. dillon, sp. nov., $P$. vallarta, sp. nov., P. phillips, sp. nov., P. yautja, sp. nov., P. peterharlli, sp. nov., P. mctiernani, sp. nov., $P$. chicano, sp. nov., and $P$. olddemon, sp. nov. Males of this new genus are easily diagnosed and separated from other Oonopinae genera by the extremely modified male chelicerae that frontally have median furrows and accentuated projections. The females can be recognized by the genitalia, which have a conspicuous posterior receptaculum, usually exposed between the epigastric folds. An auxiliary character for both sexes could be the presence of very long pairs of ventral spines with pronounced bases on the legs I and II tibiae and metatarsi. The genus is considered endemic and the species are recorded mainly from the Brazilian Atlantic Forest. An identification key is provided for all Predatoroonops species known to date.
\end{abstract}

\section{INTRODUCTION}

The small haplogyne spiders of the family Oonopidae are distributed in the temperate and tropical regions of the World (Ubick, 2005). This extremely diverse family consists of 684 species to date (Platnick, 2011), but more than 2000 species still need to be described (Baehr and Ubick, 2010; Fannes, 2010; Platnick and Dupérré, 2009b, 2010).

The Neotropical region is still poorly studied, but contributions from PBI teams currently working on material from this region will increase the number of species enormously (Grismado, 2010; Platnick and Dupérré, 2009a, 2009b; 2010). Brazil has a highly diverse goblin spider fauna as shown by surveys of the Amazonian region (Bonaldo et al., 2009a, 2009b; Bonaldo and Dias, 2010). Nevetheless, the numbers shown in those papers do not reflect the numbers of described species, since most of the recorded oonopids were identified only to morphospecies. To date only 30 species from 9 genera have been described from Brazil (Platnick, 2011) and until fairly recently the family was represented only by three endemic genera: Myrmecoscaphiella Mello-Leitão included in Gamasomorphinae, Xyccarph Brignoli and Xiombarg Brignoli, representatives of Oonopinae. Myrmecoscaphiella was recently synonymyzed with Opopaea Simon (Platnick and Dupérré, 2009a), leaving only two endemic genera from Brazil.

The study of Brazilian Oonopidae material detected a large number of probably endemic taxa that should be described in the near future. The new goblin spider genus Predatoroonops has been created for 17 new species distributed in the Atlantic Forest. To our surprise, despite the peculiar morphology of the anterior surface of the male chelicerae and lateral anterior border of carapace, no species belonging to this group had ever been described. These spiders are without scutae but with peculiar chelicerae in males and with strong pairs of ventral spines on tibae and metatarsi I and II in males and females. Dimorphic chelicerae can be found also in other goblin spider genera such as Cavisternum (Baehr et al., 2010). Whereas in Cavisternum males, the fangs are extremely long and bent, with broadened tips, the males of Predatoroonops have tiny fangs, although the paturon has strong frontal ornamentation.

Species of Predatoroonops can be recognized by dimorphic chelicerae in males, frontally with pairs of sclerotized, distally projected, and sometimes ramified apophyses in males (figs. 13-29). This frontal ornamentation of the chelicerae in oonopids is not very common, and similar cases were found to date only in species of the genus Orchestina Simon. In Orchestina, however, ornamentations are usually located medially or basally, forming a simple, rather than ramified, projection or elevation (details in Saaristo, 2001: fig. 193; Saaristo and Van Harten, 2002: fig. 56) and are probably not homologous to those of Predatoroonops.

The presence of these anterior cheliceral apophyses, together with the squared pars cephalica in males are potential synapomorphies for this genus. Although oonopids have 

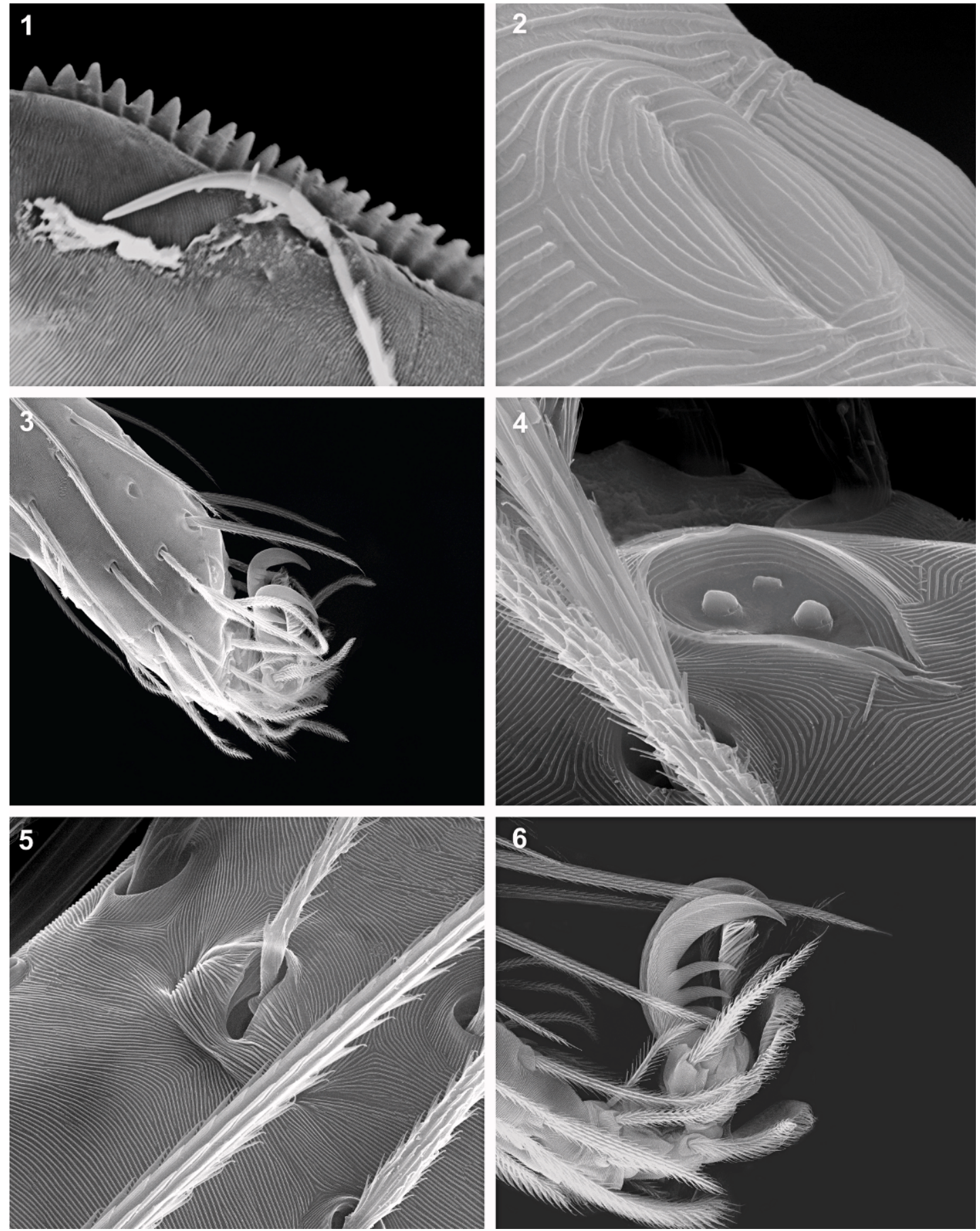

Figs. 1-6. 1, Predatoroonops mctiernani, n. sp., female, serrula. 2, P. anna, n. sp., male, leg I, slit sense organ. 3-4, P. peterharlli, n. sp.: 3, male, leg I, dorsolateral view; 4, female, leg I, tarsal organ. 5-6, P. anna, n. sp., male: 5, leg II, trichobothria, dorsal view; 6, leg IV, claws, lateral view. 
not been submitted to a thorough phylogenetic analysis, these structures are, to our best knowledge, unique among oonopids and other dysderoid spider families.

Two groups of Predatoroonops species are here proposed, based on the presence or absence of a median furrow in the frontal median area of the male chelicerae. The schwarzeneggeri group presents both median and subdistal furrows, next to the distal projections, and a long lateral sclerotized groove at the anterior lateral border of the carapace in males (figs. 13-23), delimiting laterally a strongly elevated cephalic area (figs. 39, 80). In addition to the type species, 10 species can be placed in this group: poncho, billy, valverde, blain, maceliot, anna, rickhawkins, dutch, dillon, and vallarta. The peterharlli group lacks the median and distal furrows in of the male chelicerae (figs. 24-29) and its species have the anterior lateral border of the carapace with an attenuated groove (figs. 372, 418) that can be absent (figs. 336-345). This group includes six species: $P$. peterharlli, $P$. phillips, $P$. yautja, $P$. mctiernani, $P$. chicano, and P. olddemon.

In addition to the male chelicerae, species of this genus also have characteristic female genitalia with a conspicuous posterior receptaculum, which is usually exposed between the epigastric folds. Other distinctive characters for this genus are the pairs of spines on the tibiae (five pairs) and metatarsi (three pairs), all with pronounced bases, in males and females (figs. 7, 41-42).

The male palps are apparently not useful for distinguishing species of Predatoroonops and have a very simple conformation, with a large bulb not fused to cymbium and two distal laminar, hyaline distal and subdistal processes (figs. 58-59). Interestingly, species of this genus do not have an embolus, which is replaced by a spermatic opening, located at the base of the processes, that seems to be covered by a membranous area (see details in figs. 58-59, 62-63, 111). Observations made with a compound microscope suggest that the spermatozoids are organized in a compact mass, but how this package or mass is transferred to the female is unknown. The presence of a spermatic opening hidden among distal structures appears to be common in some groups of Oonopinae and this potentially informative character should be studied in more detail in future revisions.

The morphology of the internal female genitalia is also very interesting. These species have a large receptaculum that partly emerges externally through the epigastric furrow in most of species (figs. 121, 235, 414). Internally this structure is formed by two incased pieces that fit into each other and are easily separated if pulled apart (figs. 75-77, 387388, 391-394). These pieces form an anterior elongated structure and a short posterior structure, connected by an elongated apodema plate (figs. 64-65). These structures are observed only after enzymatic clearing and we are not sure if both parts of the genitalia can be separated naturally during copula or oviposition or only if forced. Most of the recent studies on the complex female genitalia of Oonopidae were done on armored globin spiders (Fannes and Jocqué, 2008, Burger, 2010a, 2010b), only Scaphioides reducta Bryant, 1942, was studied in detail by Burger (2009). The sclerotized structures of the internal genitalia of $S$. reducta resemble those of the females of Predatoroonops (see Burger, 2009: fig. 23H), in which the anterior and posterior plates seem to be separated by an extended stalklike sclerite and, if forced, could probably separate similarly as in Predatoroonops.

The new endemic goblin spider genus Predatoroonops is the first fully revised endemic Brazilian genus and part of the worldwide revision of the Family Oonopidae conducted by the Goblin Spider PBI project (see http://research.amnh.org/oonopidae/).

\section{MATERIALS AND METHODS}

Description format follows Platnick and Dupérré (2009) and terminology of genitalic structures follows Burger (2009). Female descriptions mention only structures different from those of males, and leg spination descriptions mention only those surfaces bearing spines. Female genitalia were examined after digestion with Ultrazyme ${ }^{\circledR}$, Enzymatic Cleaner (Advanced Medical Optics, Inc.; AMO) or pancreatin solution (prepared according to Álvares-Padilla and Hormiga, 2008) at room temperature $\left(20^{\circ}-23^{\circ} \mathrm{C}\right)$ for 24 hours. All measurements are in $\mathrm{mm}$ and 

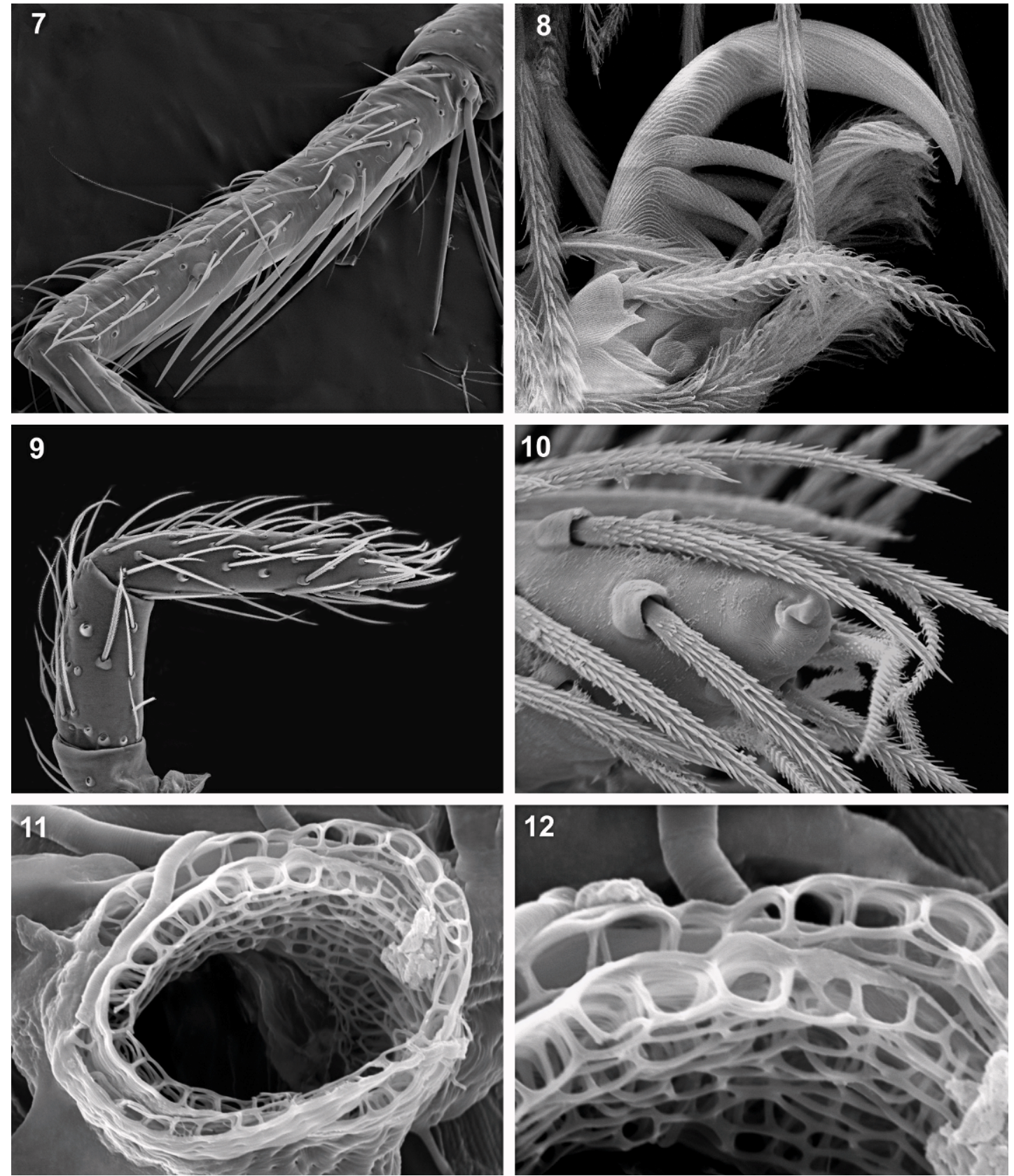

Figs. 7-12. 7, Predatoroonops anna, n. sp., male, tibia II, lateroventral view. 8, P. valverde, n. sp., female, leg IV, tarsal claws, lateral view. 9, $P$. peterharlli, n. sp., female pedipalp, prolateral view. 10, $P$. mctiernani, n. sp., female, pedipalp, detail of tip. 11-12, P. billy, n. sp., female, base of tracheal spiracle: 11, tracheal border; 12, detail of tracheal border. 

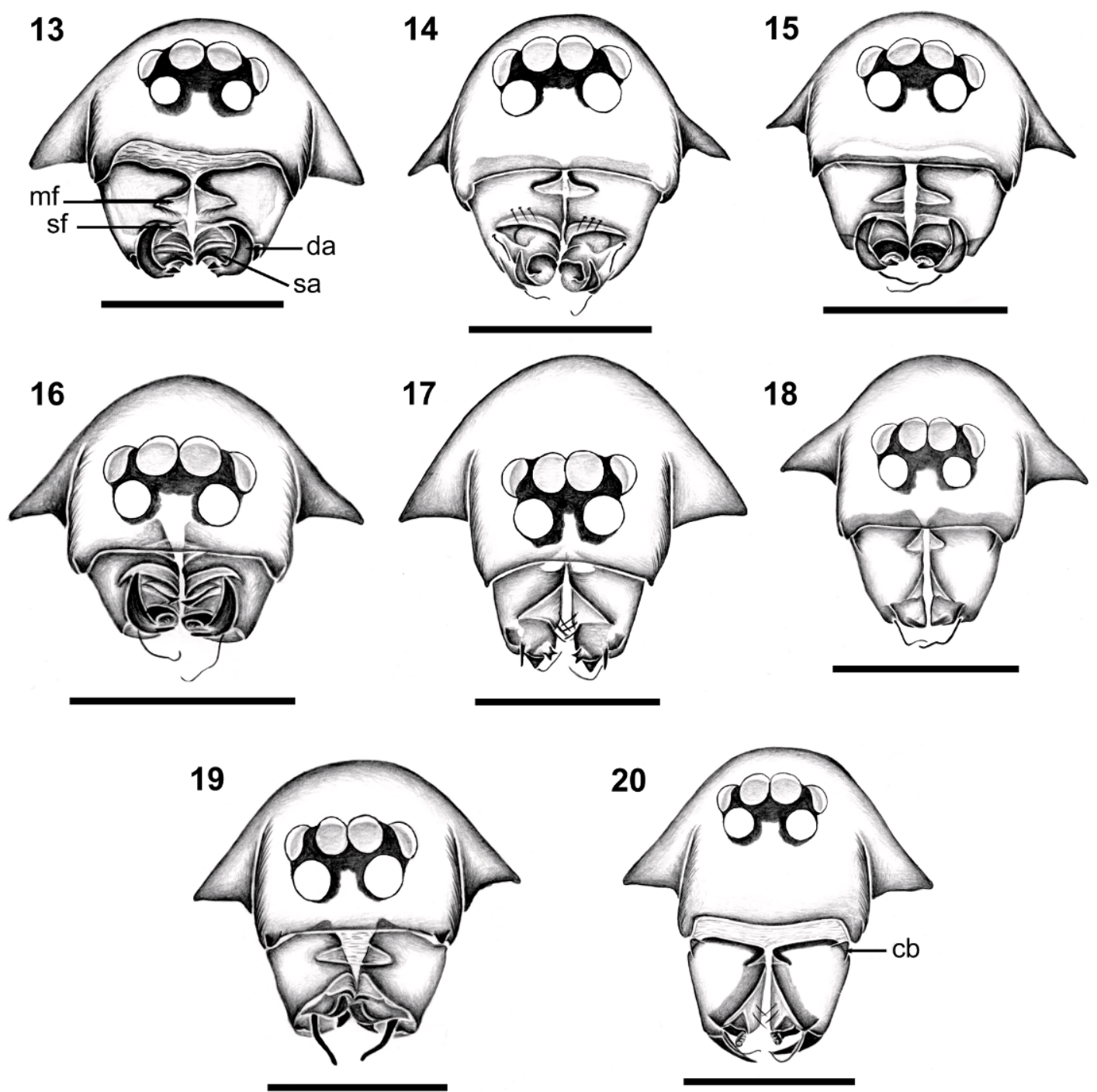

Figs. 13-20. Predatoroonops species, males, carapace and chelicerae, frontal view. 13, P. schwarzeneggeri, n. sp. 14, $P$. poncho, n. sp. 15, $P$. billy, n. sp. 16, $P$. valverde, n. sp. 17, $P$. blain, n. sp. 18, $P$. maceliot, n. sp. 19, P. anna, n. sp. 20, P. rickhawkins, n. sp. Abbreviations: $\mathbf{c b}=$ basal condyle apophysis of chelicerae; $\mathbf{d a}=$ distal apophysis of chelicerae; $\mathbf{m f}=$ median furrow of chelicerae; $\mathbf{s a}=$ subdistal apophysis of chelicerae; $\mathbf{s f}=$ subdistal furrow of chelicerae.

scale bars of drawings represent $0.1 \mathrm{~mm}$. Abbreviations are used throughout text and figures as follows: ALE, anterior lateral eyes; AME, anterior median eyes; ap, apodema plate of female epigynum; app, apodema plate process of female epigynum; ar, anterior receptaculum of female epigynum; c, cymbium; cb, basal condyle apophysis of chelicerae; co, copulatory opening; d, dorsal; da, distal apophysis of chelicerae; dp, distal process of male palp; mf, median furrow of chelicerae; p, prolateral; PLE, posterior lateral eyes; PME, posterior median eyes; pr, posterior receptaculum of female epigynum; r, retrolateral; sa, subdistal apophysis of chelicerae; sf, subdistal furrow of chelicerae; so, spermathic opening; sp, subdistal process of male palp; t, tegulum; v, ventral.

Morphological observations and illustrations were made using a Leica MZ12 

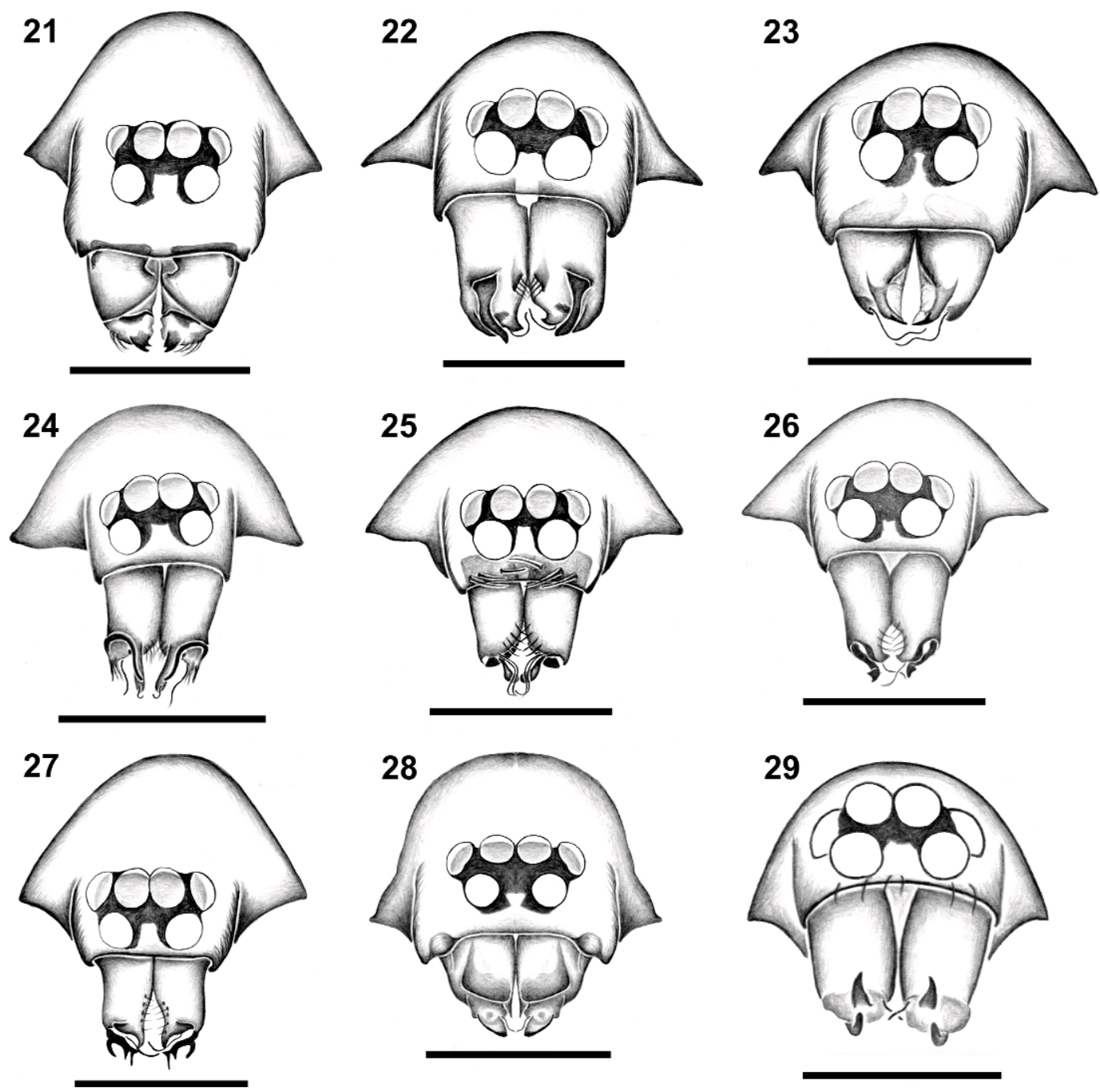

Figs. 21-29. Predatoroonops species, males, carapace and chelicerae, frontal view. 21, P. dutch, n. sp. 22, $P$. dillon, n. sp. 23, $P$. vallarta, n. sp. 24, $P$. phillips, n. sp. 25, $P$. yautja, n. sp. 26, $P$. peterharlli, n. sp. 27, P. mctiernani, n. sp. 28, P. chicano, n. sp. 29, P. olddemon, n. sp.

stereomicroscope with a camera lucida. Photographs were taken with Leica DFC 500 digital camera mounted on a Leica MZ 16A stereomicroscope. Extended focal range images were composed with Leica Application Suite version 2.5.0. Pictures of female internal genitalia were taken from temporary slide mounts in a Zeiss Axiostar Plus compound microscope equipped with a Canon Compact Digital Powershot A640 digital camera. Material for scanning electron microscopy were dried through critical-point drying or at room temperature, mounted on metal stubs using common glue or adhesive copper tape and sputter coated in gold. SEM images were taken under high vacuum in a LEO 1450VP Scanning Electron Microscope in the Laboratório de Microscopia Eletrônica do Museu Paraense Emílio Goeldi and in a Quanta 2000 SEM at Centro de Microscopia da Universidade Federal de Minas Gerais. Full-color, high-resolution versions of the images will be available on the species pages section of the Planetary Biodiversity Inventory project's website (http://research. amnh.org/oonopidae). 

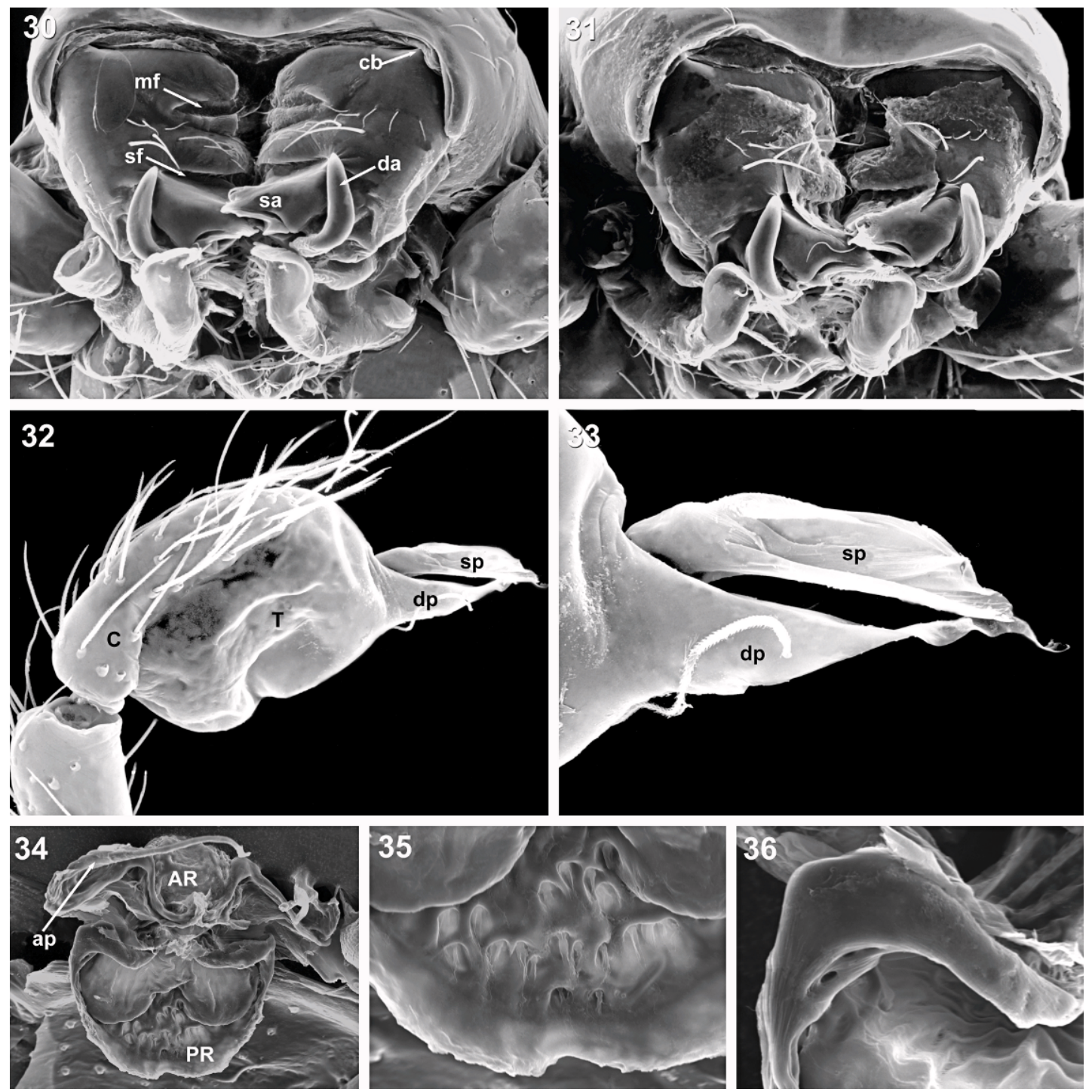

Figs. 30-36. Predatoroonops schwarzeneggeri, n. sp. 30-31, Male, chelicerae, frontal view. 32-33, Male palp: 32, cymbium and bulb, prolateral view; 33, distal process, prolateral view. 34-36, Female internal genitalia: 34, dorsal view; 35, detail of posterior receptaculum; 36, detail of border of anterior receptaculum. Abbreviations: ap = apodema plate of female epigynum; ar = anterior receptaculum; $\mathbf{c}=$ cymbium; $\mathbf{c b}=$ basal condyle apophysis of chelicerae; da $=$ distal apophysis of chelicerae; $\mathbf{d p}=$ distal process of male palp; $\mathbf{m f}=$ median furrow of chelicerae; $\mathbf{s a}=$ subdistal apophysis of chelicerae; $\mathbf{s} \mathbf{s}=$ subdistal furrow of chelicerae; $\mathbf{s p}=$ subdistal process of male palp; pr = posterior receptaculum; $\mathbf{t}=$ tegulum.

The specimens examined are deposited in the following collections (abbreviation and curator in parenthesis): American Museum of Natural History (AMNH, N.I. Platnick); Instituto Butantan, São Paulo (IBSP, D. Battesti); Museo
Argentino de Ciencias Naturales Bernardino Rivadavia, Buenos Aires (MACN, C. Scioscia); Museu Nacional do Rio de Janeiro, Rio de Janeiro (MNRJ, A.B. Kury); Western Australian Museum, Perth (WAM, M.S. Harvey). 

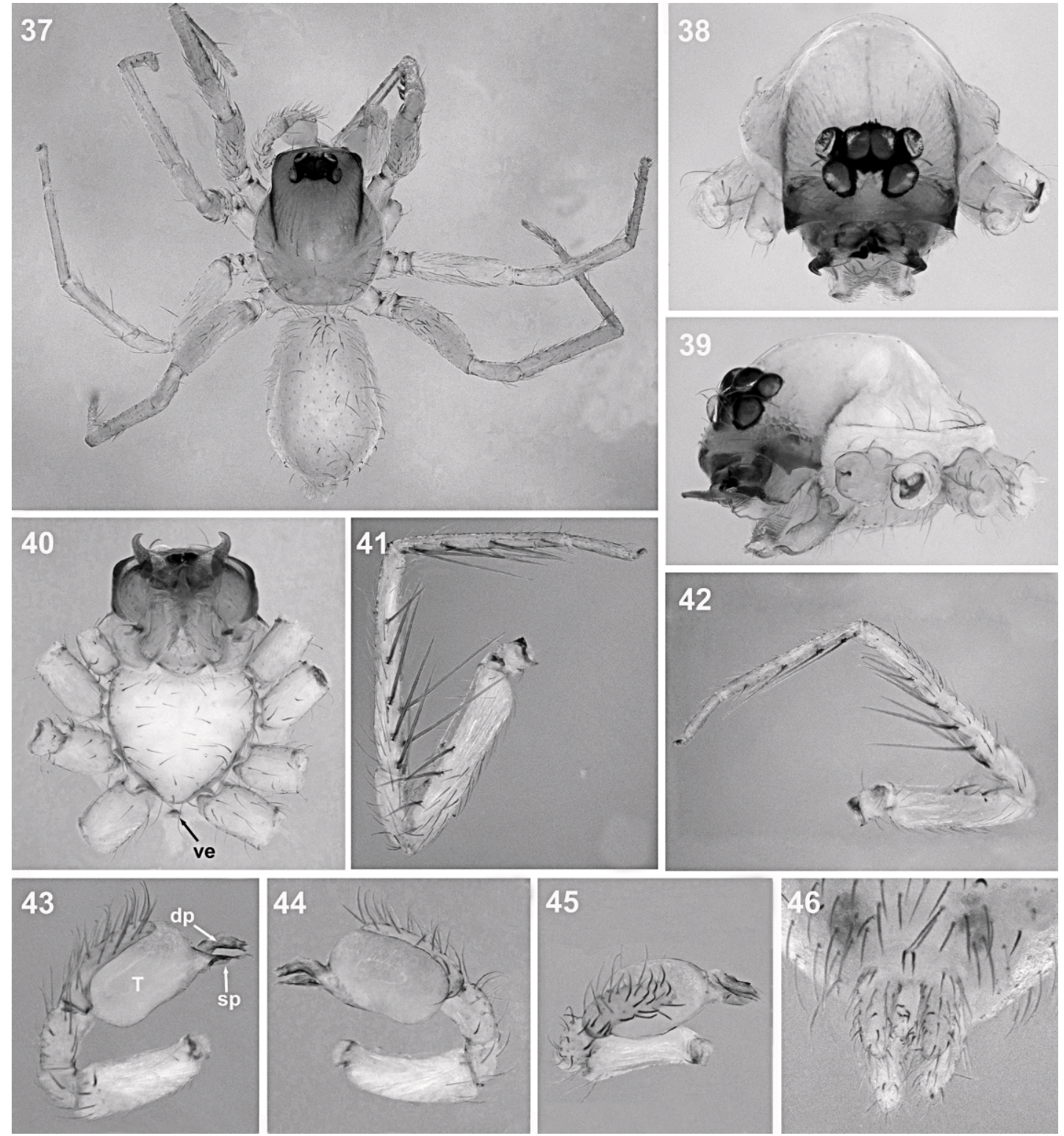

Figs. 37-46. Predatoroonops schwarzeneggeri, n. sp., male. 37, Body, dorsal view. 38-40, Carapace: 38, frontal view; 39, lateral view; 40, Ventral view. 41-42, Leg I: 41, retrolateral view; 42, prolateral view. 4345, Palp: 43, prolateral view; 44, retrolateral view; 45, dorsal view. 46, Abdomen, ventral, posterior view. Abbreviations: $\mathbf{d p}=$ distal process of male palp; $\mathbf{s p}=$ subdistal process of male palp; $\mathbf{t}=$ tegulum.

Predatoroonops Brescovit, Rheims, and Ott, new genus

TyPe SPeCIES: Predatoroonops schwarzeneggeri, new species.

ETYMOLOGY: The generic name is a contraction of "Predator Oonops," taken from the science-fiction action movie "Pred- ator." The name refers the fact that all species show the frontal area of the male chelicerae with modified structures that resemble the face of the Predator character, a technologically advanced form of extraterrestrial life. It is also a homage to the 25 th anniversary of this blockbuster success, 



Figs. 47-57. Predatoroonops schwarzeneggeri, n. sp., female. 47, Body, dorsal view. 48-51, Carapace: 48, dorsal view; 49, ventral view; 50, frontal view; 51, lateral view. 52-53, Leg I: 52, prolateral view; 53, retrolateral view. 54, Abdomen, ventral, posterior view. 55-57, Female internal genitalia: 55, ventral view; 56, dorsal view; 57, ventral view, cleared. Abbreviations: app = apodema plate process of female epigynum; ap = apodema plate of female epigynum; ar = anterior receptaculum of female epigynum; $\mathbf{p r}=$ posterior receptaculum of female epigynum.

released in the United States in 1987, and to its cast of actors and artists.

DiAgnOSIS: Males of this genus can be easily recognized and separated from other Oonopinae genera by the peculiar chelicerae, which frontally have median furrows or accentuated projections (figs. 13-31). The females can be recognized by the genitalia with conspicuous posterior receptaculum, usually exposed between the epigastric folds (figs. 99, 121, 149, 414). Additionally, both sexes present legs with very long pairs of 


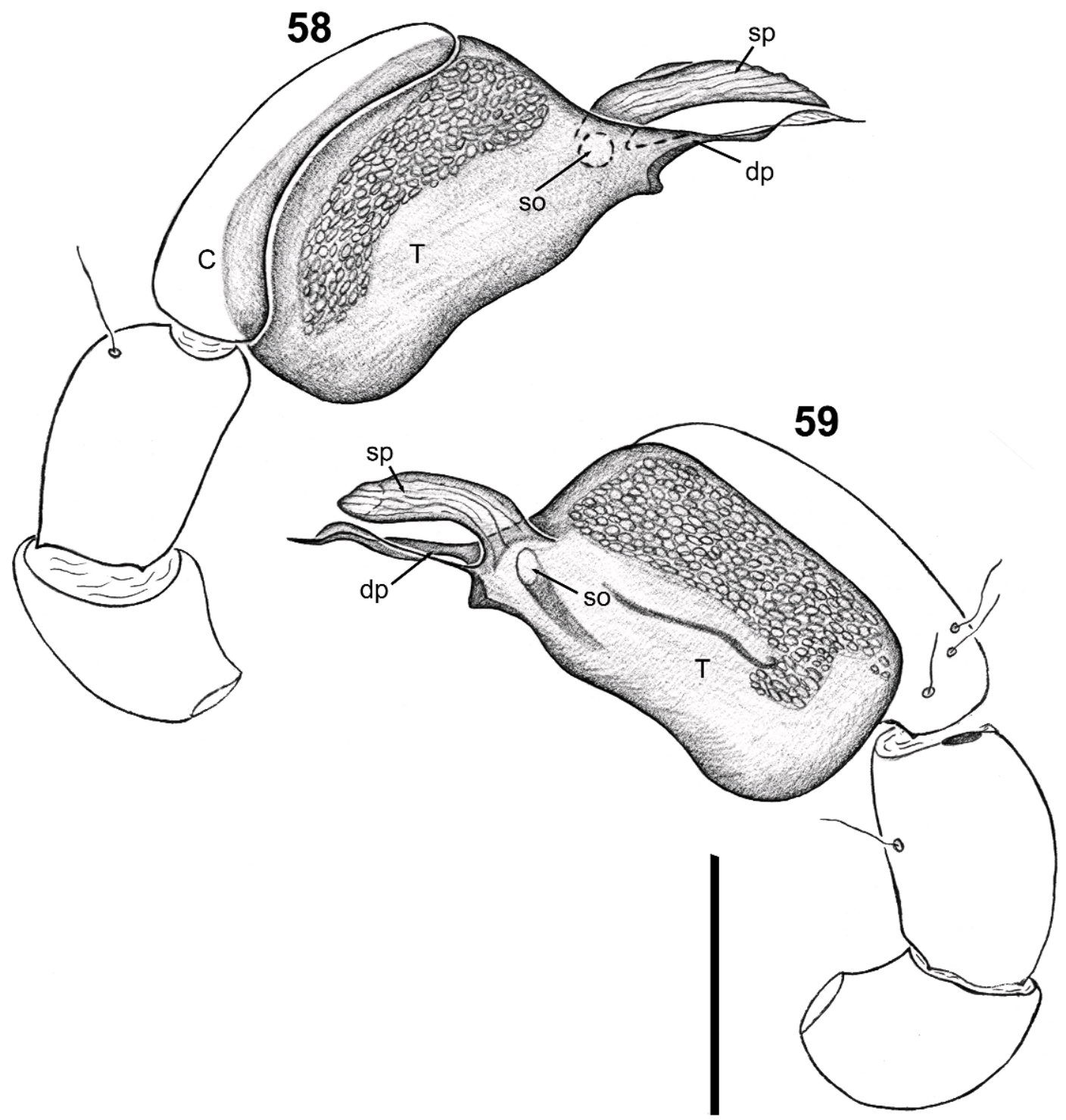

Figs. 58-59. Predatoroonops schwarzeneggeri, n. sp., male palp. 58, Prolateral view. 59, Retrolateral view. Abbreviations: $\mathbf{c}=$ cymbium; $\mathbf{d p}=$ distal process of male palp; $\mathbf{s o}=$ spermathic opening; $\mathbf{s p}=$ subdistal process of male palp; $\mathbf{t}=$ tegulum.

ventral spines on the tibia and metatarsus I and II, all with pronounced bases, as an auxiliary character (figs. 41-42; 52-53).

DESCRIPTION: Total length of males 1.052.05, of females 1.05-2.35. Carapace in dorsal view squared in males (fig. 37), broad oval in females (fig. 47); pars cephalica strongly elevated in lateral view (figs. 39, 51), anteriorly narrowed to more than 0.75 times its maximum width in males, 0.49 times its maximum width or less in females; anterior corners with strongly sclerotized triangular projections in different degrees in males (figs. 38-39; 106), absent in females (fig. 51), with rounded posterolateral corners, posterolateral edge without pits, posterior margin not bulging below posterior rim, posterolateral surface without spikes, surface of elevated portion of pars cephalica smooth, sides smooth, thorax without depressions, 

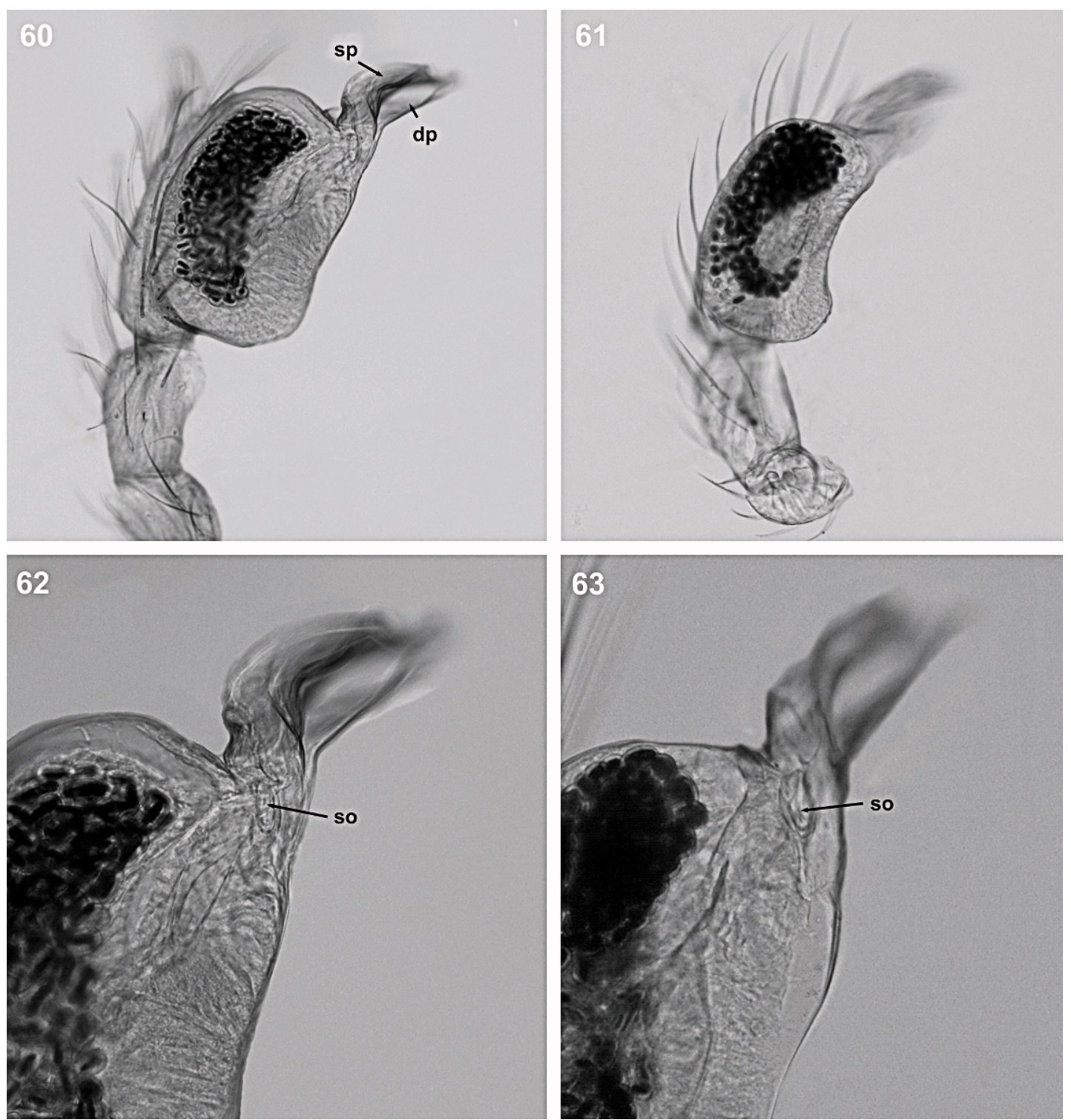

Figs. 60-63. Predatoroonops schwarzeneggeri, n. sp., male palp under compound microscopy. 60, Retrolateral view. 61, Ventral view. 62, Distal area, detail of duct and spermatic opening. retrolateral view. 63, Distal area, detail of spermatic opening, retrolateral view. Abbreviations: dp $=$ distal process of male palp; so $=$ spermathic opening; $\mathbf{s p}=$ subdistal process of male palp; $\mathbf{t}=$ tegulum.

fovea absent, without radiating rows of pits (fig. 48); lateral margin straight, smooth, without denticles; plumose setae near posterior margin of pars thoracica absent. Clypeus margin slightly rebordered (figs. 31, 38), curved downwards in frontal view, vertical in lateral view in males, with length equal or slightly larger than the diameter of AME (figs. 14-15), except Predatoroonops rickhawkins, with two times the diameter of ALE (fig. 20), low in females (figs. 50, 92), median projection absent. Clypeal distinct setae present in males of $P$. yautja (fig. 25), $P$. olddemon (fig. 29), in the rest needlelike setae. Chilum absent. Six eyes, well developed (figs. 13-29; 38), PME largest, all eyes oval, 
64
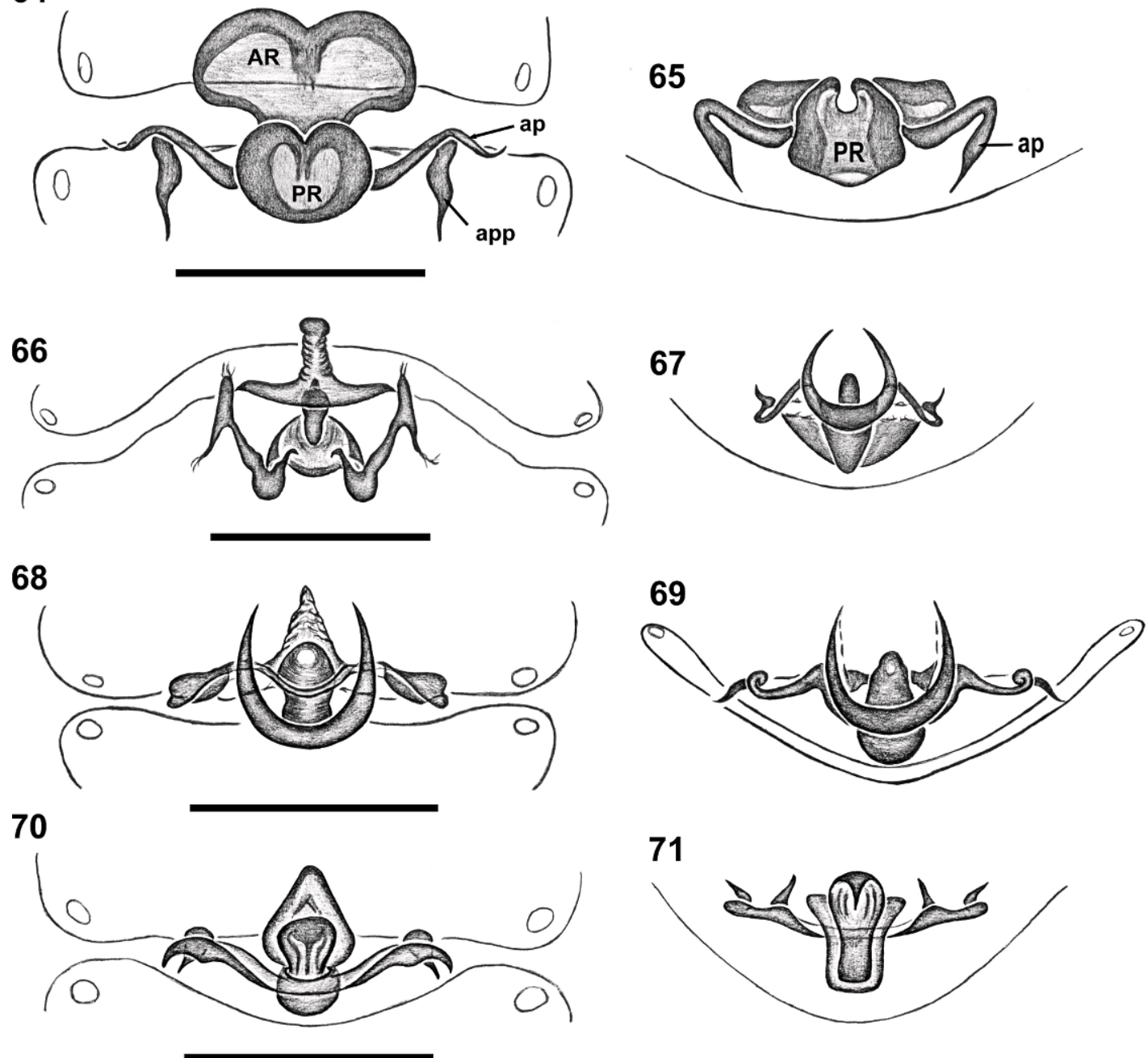

Figs. 64-71. Predatoroonops species, female internal genitalia. 64-65, Predatoroonops schwarzeneggeri, n. sp.: 64, dorsal view; 65, posterior view. 66-67, P. poncho, n. sp.: 66, dorsal view; 67, posterior view. 6869, P. billy, n. sp.: 68, dorsal view; 69, posterior view. 70-71, P. valverde, n. sp.: 70, dorsal view; 71, posterior view. Abbreviations: ap = apodema plate of female epigynum; app = apodema plate process of female epigynum; ar = anterior receptaculum of female epigynum; pr = posterior receptaculum of female epigynum.

posterior eye row recurved from both above and front ocular area setae absent (figs. 3738), ALE separated from edge of carapace by their radius or more, ALE separated by more than diameter in males, by less than their radius in females; ALE-PLE and PLE-PME touching in males, ALE-PLE and PLE-PME separated by less than PME radius in females, PME contiguous throughout most of their length. Sternum smooth, wider than long, not fused to carapace (figs. 39-40), anterior corner unmodified, median concavity absent, without radial furrows between coxae, extensions of precoxal triangles present, lateral margins unmodified, radial furrow opposite coxae III absent, surface smooth, without pits, microsculptures absent, sickle-shaped structures absent, anterior margin unmodified, posterior margin not extending posteriorly of coxae IV, lateral margin 

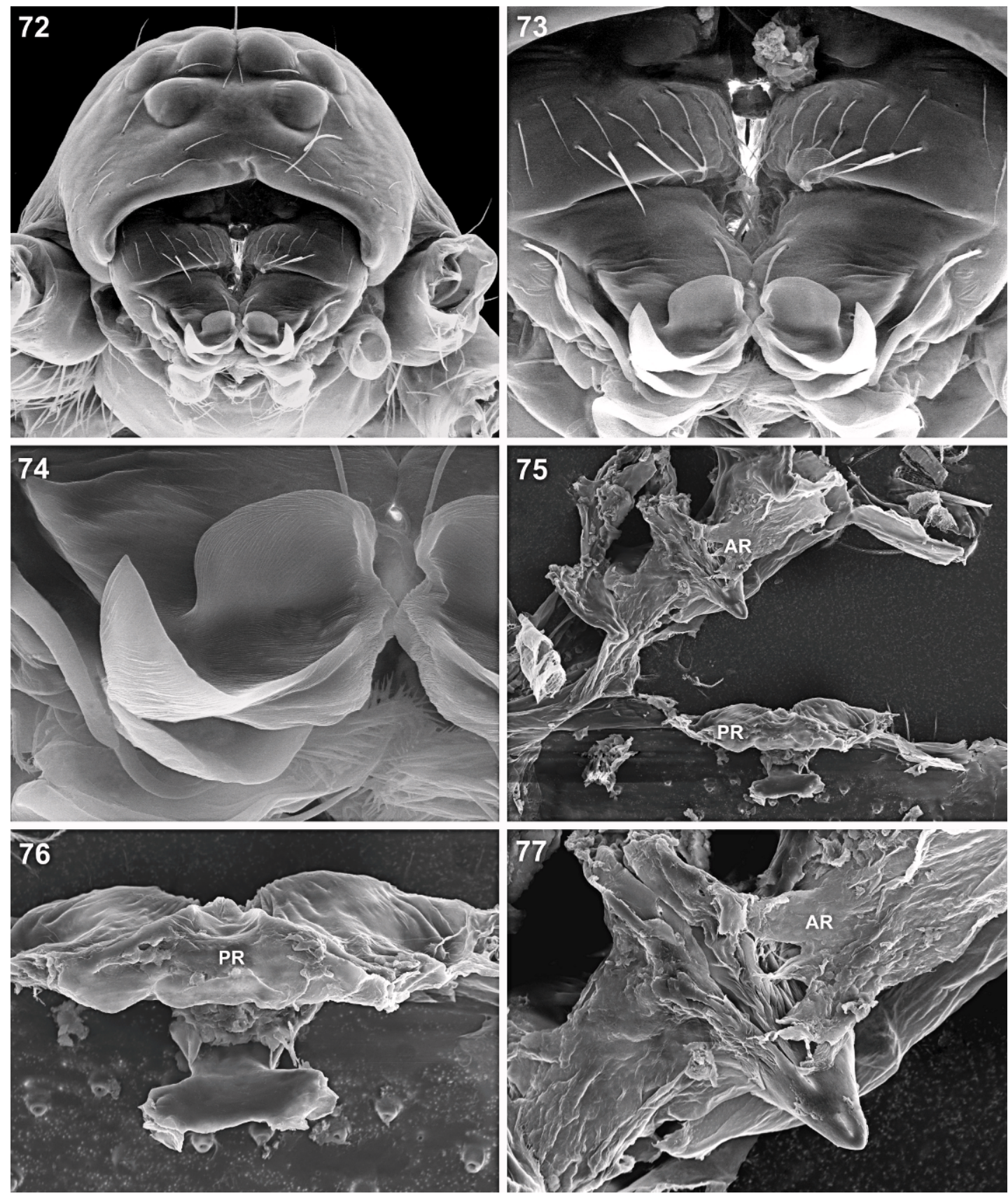

Figs. 72-77. Predatoroonops poncho, n. sp., male. 72, Carapace, frontal view. 73, Chelicerae, frontal view. 74, Distal apophysis of chelicerae, frontal view. 75-77, Female, internal genitalia, dorsal view: 75, anterior and posterior receptaculum separated; 76, detail of posterior receptaculum; 77, detail of anterior receptaculum. Abbreviations: $\mathbf{a r}=$ anterior receptaculum of female epigynum; pr $=$ posterior receptaculum of female epigynum. 

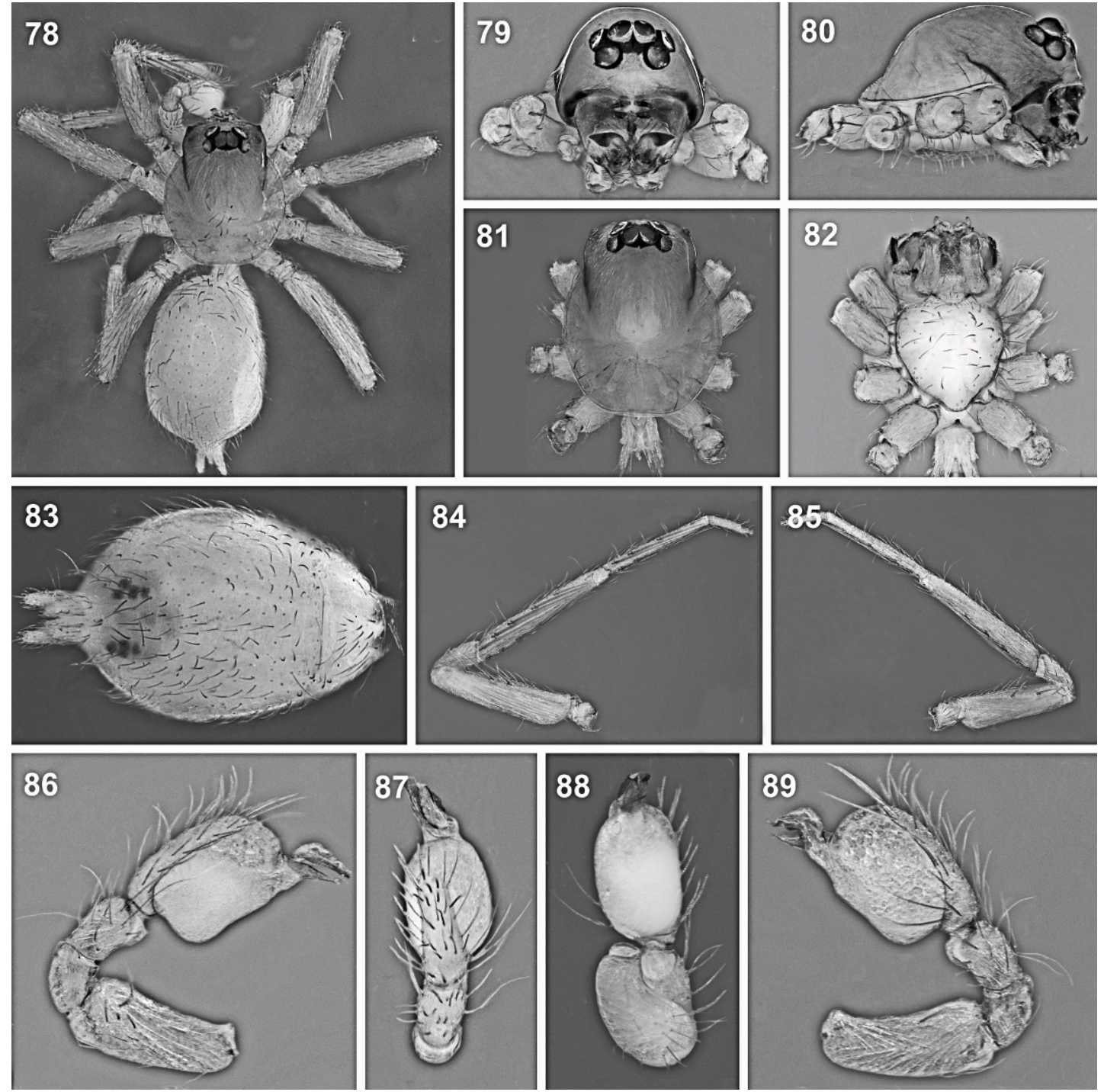

Figs. 78-89. Predatoroonops poncho, n. sp., male. 78, Body, dorsal view. 79-82, Carapace: 79, frontal view; 80, lateral view; 81, dorsal view; 82, ventral view. 83, Abdomen, ventral view. 84-85, Leg I: 84, retrolateral view; 85, prolateral view. 86-89, Palp: 86, prolateral view; 87, dorsal view; 88, ventral view; 89, retrolateral view.

without infracoxal grooves, distance between coxae approximately equal, without posterior hump; setae sparse, dark, needlelike, evenly scattered, originating from surface, without hair tufts. Mouthparts: chelicerae straight, modified frontally with distal and subdistal apophysis in males (figs. 13-29), unmodified in females (fig. 50), promargin and retromargin without teeth (figs. 199, 209-211), without toothlike projections, directed medi- ally, shape normal, tip unmodified; setae needlelike, evenly scattered; paturon distal region unmodified, posterior surface unmodified, promargin and inner margin unmodified, without prominent basal process, laminate groove absent, setae dark, shaggy hair at fang base (figs. 16, 18, 198, 305), paturon inner margin with brush. Labium rectangular, anterior margin not indented at middle (figs. 107, 309, 410), with 4-6 setae (fig. 410), 

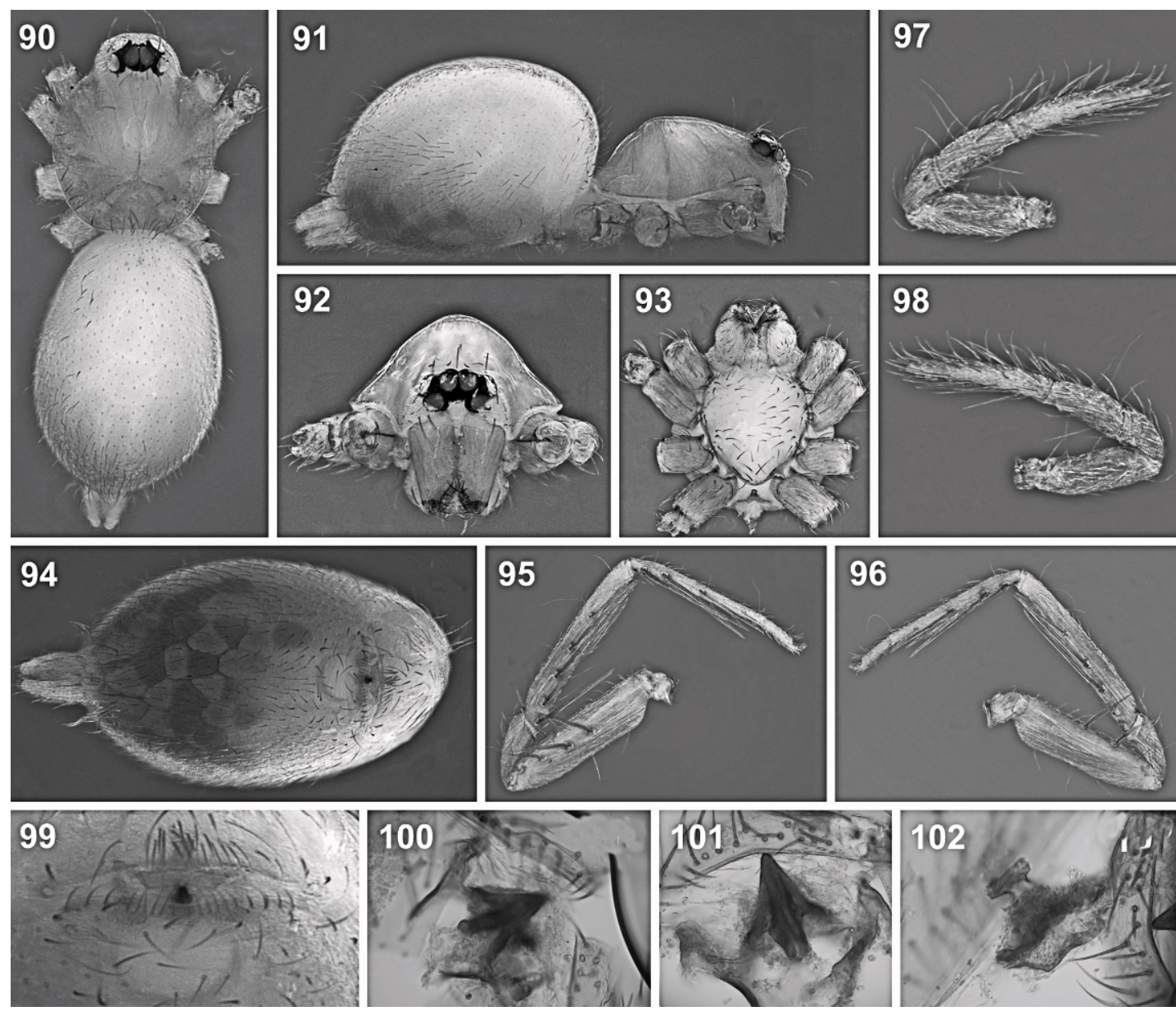

Figs. 90-102. Predatoroonops poncho, n. sp., female. 90-91, Body: 90. dorsal view; 91, lateral view. 9293, Carapace: 92, frontal view; 93, ventral view. 94, Abdomen, ventral view. 95-96, Leg I: 95, retrolateral view; 96, prolateral view. 97-98, Pedipalp: 97, prolateral view. 98, retrolateral view. 99-102, Internal genitalia: 99, ventral view; 100-102, dorsal view by transparence; 100. anterior receptaculum; 101, anterior receptaculum, detail; 102, posterior receptaculum.

not fused to sternum, same as sternum in sclerotization. Labrum anterior margin not indented at middle, covered with needlelike setae (fig. 410). Endites distally excavated in males (figs. 306, 362), not excavated distally in females (fig. 325), same as sternum in sclerotization, anteromedian part with retrolateral groove, serrula present in single row (fig. 1), posteromedian part unmodified. Female palp claws, spines, and trichobothria absent; tarsus unmodified (figs. 9-10). Abdomen ovoid (figs. 37, 47), without long posterior extension, rounded posteriorly (fig. 47); dorsum without color pattern (figs. 47, 90). Book lung covers small, narrow, without setae, anterolateral edge large and oval (fig. 173). Posterior spiracles not connected by groove. Pedicel tube short, with ventral sclerotization (figs. 40, 82), dorsum setae present, dark, needlelike, scuto-pedicel region unmodified, plumose hairs absent, matted setae on anterior ventral abdomen in pedicel area absent, cuticular outgrowths near pedicel absent. Dorsal scutum absent. Epigastric area dark, without scutum. Postepigastric scutum absent. Spinneret scutum absent. Supraanal scutum absent. Epigastric area setae uniform, dark, needlelike (fig. 83). 

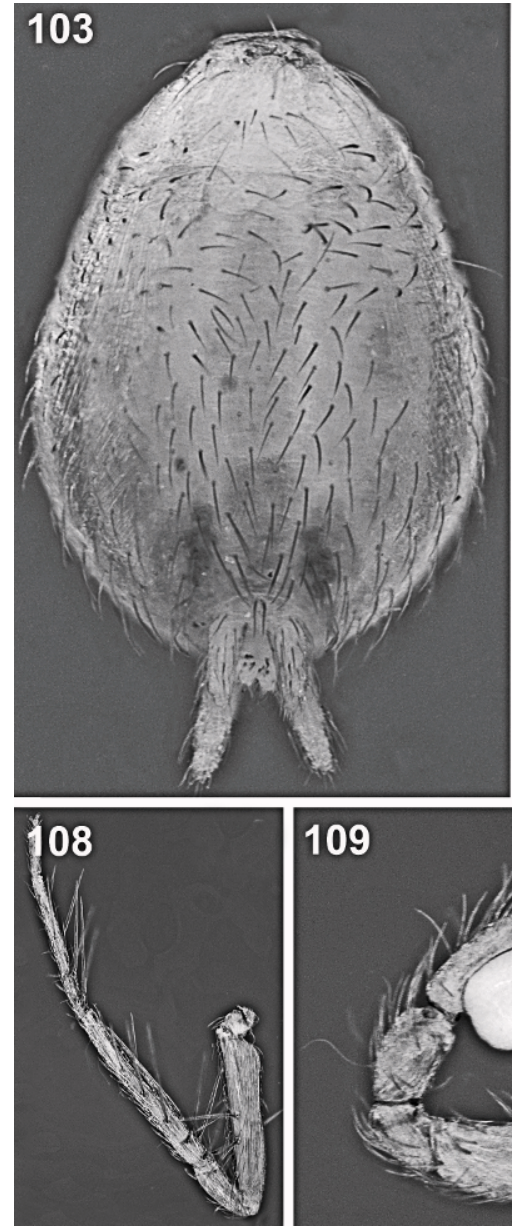
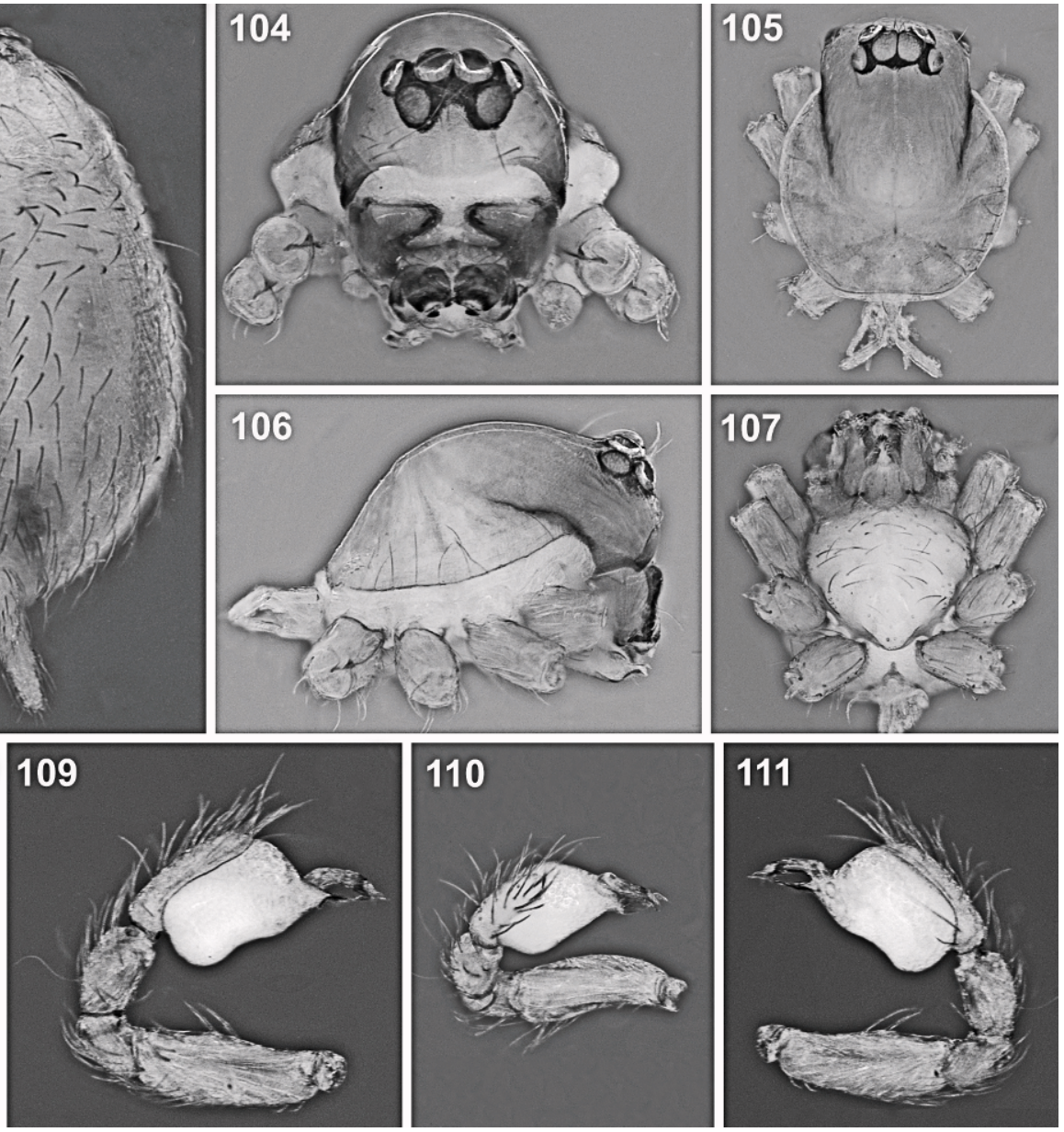

Figs. 103-111. Predatoroonops billy, n. sp., male. 103, Abdomen, ventral view. 104-107, Carapace: 104, frontal view; 105, dorsal view; 106, lateral view; 107, ventral view. 108, Leg I, retrolateral view. 109-111, Palp: 109, prolateral view; 110, dorsal view; 111, retrolateral view.

Spinneret scutum without fringe of setae. Dense patch of setae anterior to spinnerets absent. Colulus replaced by two setae (figs. 46, 54, 103). Legs without color pattern (figs. 41-42); patella plus tibia I longer than carapace, femur IV not thickened, same size as femora I-III, tibia I unmodified, tibia I Emerit's glands absent, tibia IV specialized hairs on ventral apex absent, tibia IV ventral scopula absent, metatarsi I-II mesoapical comb absent, metatarsi III-IV weak ventral scopula absent. Leg spines present, only surfaces bearing spines presented in the species description, all spines longer than the width of leg segments (figs. 7, 52-53), tarsal proclaws and retroclaws inner face striate (figs. 6, 8); tarsi I-IV superior claws tooth examined in detail: tarsus I-III superior claws with four teeth on lateral surface of proclaw (figs. 6, 8), teeth on median surface absent, four teeth on lateral surface of retroclaw, teeth on median surface absent; tarsus I-IV without inferior claw; onychium short with short setae (fig. 6), trichobothria examined in detail with SEM, tibia: each with three; metatarsus: each with one; base longitudinally narrowed, hood covered by numerous low, closely spaced ridges, aperture internal texture gratelike (fig. 5). Tarsal organ with 3 sensilla visible (fig. 4). Male genitalia: epigastric region with sperm pore not visible; furrow without $\Omega$-shaped insertions, without 


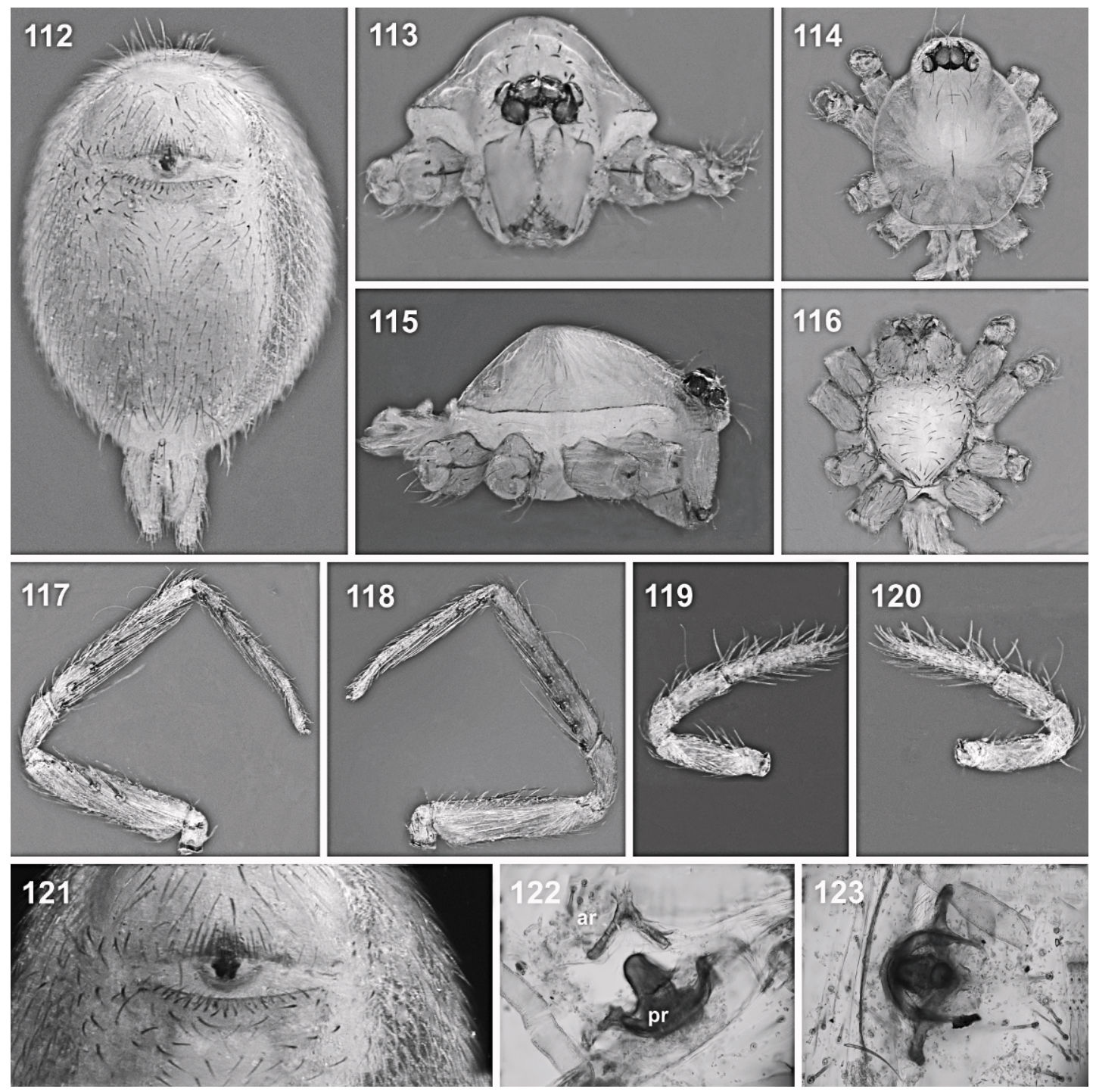

Figs. 112-123. Predatoroonops billy, n. sp., female. 112, Abdomen, ventral view. 113-116, Carapace: 113, frontal view; 114, dorsal view; 115, lateral view; 116, ventral view. 117-118, Leg I: 117, prolateral view. 118, retrolateral view. 119-120, Pedipalp: 119, retrolateral view; 120, prolateral view. 121-123, Internal genitalia: 121, ventral view; 122, ventral view, cleared; 123, dorsal view. Abbreviations: ar $=$ anterior receptaculum of female epigynum; pr $=$ posterior receptaculum of female epigynum.

setae. Palp normal size, not strongly sclerotized, right and left palps symmetrical; trochanter normal size, unmodified; femur normal size, without posteriorly rounded lateral dilation, attaching to patella basally; femur two or more times as long as trochanter, patella shorter than femur, not enlarged, without prolateral row of ridges, setae unmodified; tibia with 1-2 trichobothria (figs. 58-59), cymbium ovoid in dorsal view (fig. 45), fused with bulb but with clearly defined seam between (fig. 44), not extending beyond distal tip of bulb, plumose setae absent, without stout setae, without distal patch of setae; tarsal organ close to retrolateral margin, with two visible sensilla, bulb stout, shorter than cymbium, spherical, distal part with insertion area of distal process presenting a narrowed base 
accommodating a subdistal larger laminar and hyaline process and a distal slender hyaline process (figs. 32-33), embolus absent, replaced by a large and circular spermatic opening between the base of the hyaline process (figs. 58-59, 61-63, 88, 139). Female genitalia in ventral view showing part of the basis of the large receptaculum (figs. 112, 121, 235, 414, 433) between the epigastric furrow, receptaculum formed by two incased pieces that fit into each other and can be pulled apart easily (figs. 75-77, 387-388, 391-394); anterior receptaculum generally elongated and short posterior receptaculum connected with elongated apodema plate (figs. 64-65); apodema plate consists of a narrow, long or short submedian process, which is sometimes sinuous (figs. 34, 56-57, 64-65).

ReMARKS: The genus Predatoroonops includes 17 endemic species, occurring mainly in the Brazilian Atlantic Forest, most of them in high mountainous areas. The genus is here divided into two groups and the type species is treated first followed by other species in groups according to the morphology of the cheliceral structures, a putative synapomorphy for this genus.

\section{KEY TO SPECIES OF PREDATOROONOPS}

1. Males. . . . . . . . . . . . . . . . . 2

- Females (unknown in P. phillips) . . . . 18

2. Chelicerae with one or two frontal furrows ...3

- Chelicerae without frontal furrow. . . . . 13

3. Chelicerae with median furrow absent and distal dorsally curved apophysis (fig. 23) ........... ............. P. vallarta Chelicerae with median furrow present. . . 4

4. Chelicerae with subdistal furrow inconspicuous, presenting a group of setae (fig. 22) . . . . . . . ................ P. dillon Chelicerae with well-developed subdistal furrow (figs. 13-21) . . . . . . . . . . . 5

5. Chelicerae with distal dorsally curved apophysis (fig. 13) . . . . . . . . . . . . 6 Chelicerae without distal dorsally curved apophysis............... 9

6. Chelicerae with distal dorsally curved apophysis long. . . . . . . . . . . . . 7 Chelicerae with distal dorsally curved apophysis short (fig. 14) . . . . . . . P. poncho

7. Chelicerae with long median furrow, occupying almost all anterior surface (fig. 16). . P. valverde
Chelicerae with shorter median furrow occupying half of anterior surface (figs. 13, 15) . . 8 8

8. Chelicerae with distal apophysis narrow, without apophysis on the basal condyle (fig. 13) . . . . . . . . P. schwarzeneggeri Chelicerae with distal apophysis wide, with apophysis on the basal condyle (fig. 15). . . . . .

9. Chelicerae with apophysis on basal condyle (figs. 18-21) . . . . . . . . . . . . . 10 Chelicerae without apophysis on the basal condyle (fig.17) . . . . . . . . P. blain

10. Clypeus two times longer than diameter of the OMA; median furrow very small (fig. 20) ............ P. rickhawkins Clypeus as long as diameter of OMA; median furrow conspicuous (fig. 18) . . . . . . 11

11. Chelicerae with distal apophysis elongated, very narrow and subdistal apophysis curved (fig. 19) . . . . . . . . . . . P. anna Chelicerae with distal and subdistal apophysis short (figs. 18, 21). . . . . . . . . 12

12. Chelicerae with distal apophysis distally bifid, median furrow short (fig. 21) . . . P. dutch Chelicerae with distal apophysis area truncated, median furrow triangular (fig. 18). . . . . . .

\section{P. maceliot}

13. Clypeus with distinct and robust needlelike setae (figs. 25, 29) . . . . . . . . . . 14 Clypeus without robust needlelike setae (figs. 24, 26-28). . . . . . . . . . . 15

14. Subdistal apophysis curved dorsally (fig. 29).... .............. P. olddemon Subdistal apophysis long, racket shaped at tip (fig. 25) . . . . . . . . . . P. yautja

15. Chelicerae with very large quadrate projection on the middle surface (fig. 28). . . . . . .

$$
\text { P. chicano }
$$

Chelicerae without frontal projection . . 16

16. Distal apophysis forming a slender sclerotized black branch with narrow tip (figs. 24, 335) ............. P. phillips Distal apophysis forming a slender sclerotized black branch with flattened tips (figs. 2627) . . . . . . . . . . . . . . . 17

17. Distal apophysis trifid on the distal area (figs. 27, 417-419) . . . . . . . P. mctiernani Distal apophysis sinuous, sulcated at tip (figs. 26, 370-371) . . . . . . . P. peterhalli

18. Anterior receptaculum larger than posterior receptaculum (figs. 64, 395) . . . . . . . 19 Anterior receptaculum smaller than or of similar size as posterior receptaculum (figs. 66, 68, 182) . . . . . . . . 20

19. Anterior receptaculum cordiform, apodema plate M-shaped (fig. 64). . . . . . . . . . . . . 
Anterior receptaculum subrectangular, apodema with coiled base (fig. 395) . . . . . . . . . ............ P. peterhalli

20. Anterior and posterior receptaculum fused almost indistinguishable (figs. 397, 399) . . . 21 Anterior and posterior receptaculum easily distinguishable (figs. 66, 177) . . . . . . . 22

21. Receptaculum peanut shaped (fig. 399) .... . . . .............. . chicano Receptaculum rectangular (fig. 397). . . . . . .

P. metiernani

22. Posterior receptaculum large, squared, with very short anterior receptaculum (figs. 278279) . . . . . . . . . . . . P. dillon Posterior receptaculum not larger than the anterior receptaculum (figs. 68, 70, 282) . . 23

23. Anterior receptaculum $\mathrm{T}$-shaped distally (fig. 182). . . . . . . . . . . . . 24 Anterior receptaculum not T-shaped . . . 26

24. Apodema process originating at the middle of the apodema plate (fig. 401). . . . . . . .

P. olddemon Apodema process originating at the distal third of the apodema plate (figs. 182, 282) . . . . 25

25. Posterior receptaculum cordiform (fig. 182)............. P. rickhawkins Posterior receptaculum nose shaped (fig. 282) . . . . . . . . . . P. yautja

26. Anterior receptaculum subtriangular (figs. 68 ,

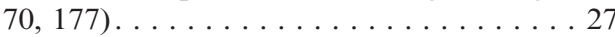
Anterior receptaculum cylindrical (figs. 66, 179) . . . . . . . . . . . . . . . . . 29

27. Posterior receptaculum cylindrical, apodema plate flattened distally (figs. 68, 70) . . . . 28 Posterior receptaculum globose, apodema plate coiled, slender in the distal area (fig. 177). . . . . . . . . . P. maceliot

28. Apodema plate U-shaped, flattened, posterior receptaculum elongated distally (figs. 70 71)............ P. valverde Apodema plate narrow medially, posterior receptaculum U-shaped distally (figs. 68-

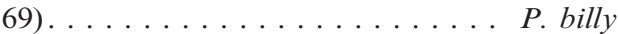

29. Apodema plate Z-shaped; posterior receptaculum large, rounded at tip (figs. 66-67) . . . . . . .............. P. poncho Apodema plate not Z-shaped, posterior receptaculum small, with variable tip (figs. 174, 179, 276) . . . . . . . . 30

30. Apodemaplate U-shaped in ventral view (figs. 174, 276, 280) . . . . . . . . . . . 31 Apodema plate long and crossed in the distal area in ventral view (fig. 179) . . . . P. anna

31. Posterior receptaculum with elongated distal area (figs. 174, 280) . . . . . . . . . . . 32 Posterior receptaculum not elongated in the distal area (fig. 276). . . . . . . . P. dutch
32. Posterior receptaculum drop shaped; apodema plate with sinuous apodema process (figs. 280-281). . . . . . . . . P. vallarta Posterior receptaculum cylindrical, with elongated distal area, apodema plate with curved apodema process (figs. 174-176) . . . P. blain

\section{The schwarzeneggeri Group}

This group is characterized by the presence of a distinctive median furrow and a subdistal furrow on the prolateral surface and distal projections of the chelicerae (figs. 1322 ); and a long, sclerotized groove at the lateral anterior border of the carapace, with the cephalic area strongly elevated (figs. 39, 80). Eleven species are herein included: schwarzeneggeri (the type species), poncho, billy, valverde, blain, maceliot, anna, rickhawkins, dutch, dillon, and vallarta.

\section{Predatoroonops schwarzeneggeri Brescovit, Rheims, and Ott, new species Figures 13, 30-65; map 1}

TyPES: Male holotype and female paratype from Fazenda Santa Helena, Pinheiral, $22^{\circ} 31^{\prime} 12^{\prime \prime} \mathrm{S}, 43^{\circ} 59^{\prime} 48^{\prime \prime} \mathrm{W}$, Rio de Janeiro, Brazil (Nov. 5-11, 1999, A.D. Brescovit et al.), deposited in IBSP 66880 (PBI_OON 10909) and IBSP 66878 (PBI_OON 10910), respectively.

ETYMOLOGY: The specific name is a patronym in honor of the main actor in "Predator" movie, Arnold Schwarzenegger, who plays Major Alan "Dutch" Schaefer, the leader of a Special Forces elite team on a mission to rescue hostages from guerrilla territory in Central America.

DiAgNosis: Males of Predatoroonops schwarzeneggeri resemble those of $P$. billy and $P$. valverde by the long and dorsally curved distal apophysis at the chelicerae (figs. 15-16) but can be distinguished from these species by the larger median furrow, very narrow subdistal furrow, absence of condylar apophysis (fig. 13). Females can be easily distinguished from all other species by the large cordiform anterior receptaculum, with $\mathbf{M}$-shaped apodema plate with lateral apodema process (fig. 64) in the internal genitalia.

MAle (PBI_OON 10909): Total length 1.88. Carapace 0.85 long, 0.68 wide. Eyes: ALE 0.10, PLE 0.10, PME 0.10, ALE-ALE 


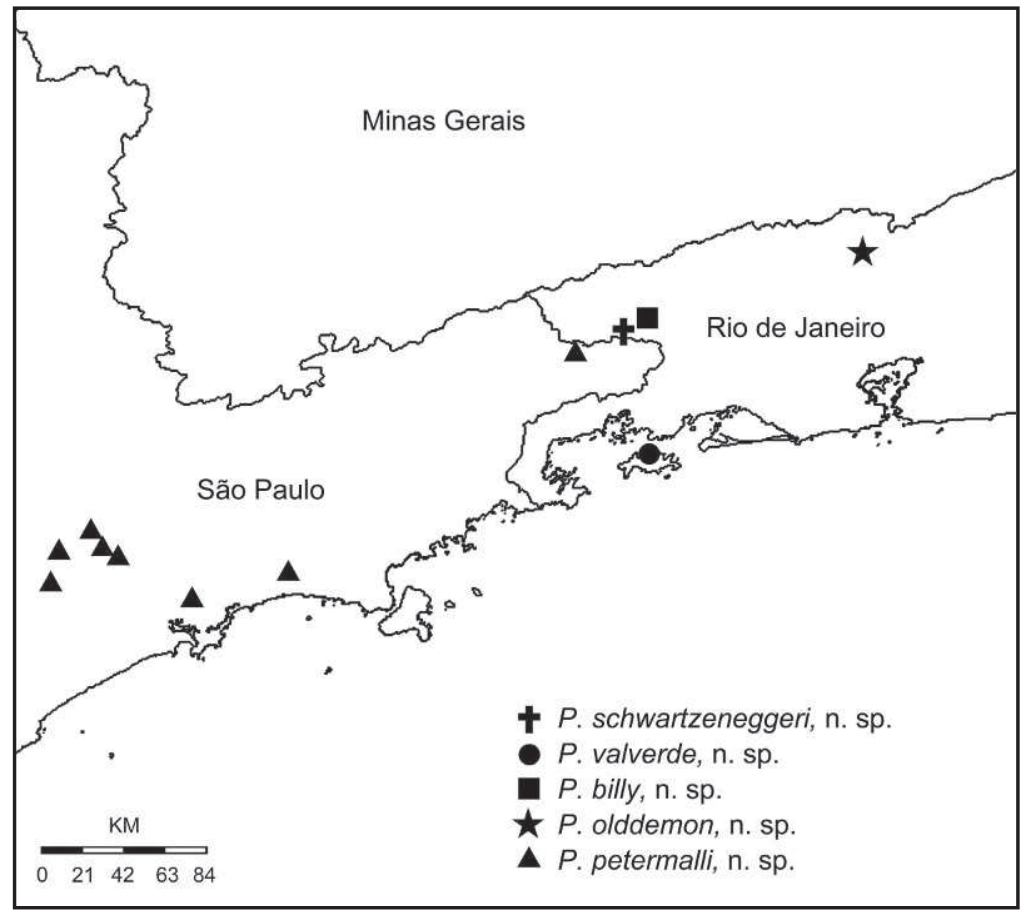

Map 1. Distribution of five new Predatoroonops species in southeastern and eastern Brazil: Predatoroonops schwartzeneggeri, P. valverde, P. billy, P. olddemon, and P. peterhalli.

0.06. Carapace pale orange, with brown stripe along margin of cephalic area (fig. 38), anterolateral corners with sclerotized triangular projection (fig. 39). Chelicerae brown. Sternum, endites, and labium yellow. Clypeus with very small needlelike setae (fig. 13). Chelicerae anterior face with large triangular median furrow, subdistal narrow furrow, lateral subdistal apophysis, dorsally curved distal apophysis and subtriangular condyle apophysis (fig. 13). Abdomen dorsum white. Legs yellow, femur I 0.7 long. Leg spination: femur I v2-2-2; II d1-0-0; v2-2-2; tibia I v2-22-2-2, II v2-2-2-2-2, III, IV d1-0-0; metatarsi: I-II v2-2-2. Male palp proximal segments yellow; cymbium yellow, bulb white, slender hyaline process with large base (fig. 43).

Female (PBI_OON 10910): Total length 2.10. Carapace 0.86 long, 0.77 wide. Eyes: ALE 0.10, PLE 0.10, PME 0.12, ALE-ALE 0.08. Carapace without pattern. Chelicerae, endites, and labium yellow. Abdomen dorsum white. Leg spination: femur I v2-1-2; II v2-2-0; III, IV d1-0-0; tibia I 2-2-2-2-2, II 2-22-2-2, III d0-1-0; p1-1-0; r0-1-0; IV p1-1-0; v0-0-2; r1-1-0; metatarsus I 2-2-2-2, II 2-2-22, III d0-1-0; v0-0-2; IV p0-1-1; v0-1-2; r0-11. Internal genitalia with cordiform anterior receptaculum and cordiform posterior receptaculum (figs. 56, 64); M-shaped apodema plate with elongated apodema process (figs. 56-57, 64-65).

OTHER MATERIAL EXAMINED: BRAZIL: Rio de Janeiro: Pinheiral, 22 $31^{\prime} 12^{\prime \prime}$ S, $43^{\circ} 59^{\prime} 48^{\prime \prime} \mathrm{W}$, Fazenda Santa Helena, $22^{\circ} 34^{\prime} \mathrm{S}$, $44^{\circ} 21^{\prime} \mathrm{W}$, Nov. 5-11, 1999 (IBSP 66862, PBI_OON 10975), 1 ; ; (IBSP 66864, PBI_OON 11006), 1 $\delta$; (IBSP 66868-66869, PBI_OON 11004; 11119), 20; (IBSP 66869-66870, PBI_OON 11005; 11119), $1 \hat{\delta}$; (IBSP 66877, PBI_11009), 1 $\hat{\delta}$; (IBSP 66881, PBI_OON 11002), 1 ; (IBSP 66884, PBI_OON 11008), $2 \hat{\delta} 1$ i ; (IBSP 66886, PBI_OON 11120), $1 \hat{\delta}$; (IBSP 66890-66891, PBI 11003; 10974), 1 of 1 웅 (IBSP 160842, PBI_OON 11007), 1 ; ; (IBSP 160843, PBI_OON 11106), 2 s ; all collected by A.D. Brescovit.

DisTRIBUTION: Known only from the type locality, in the state of Rio de Janeiro, Brazil (map 1) 

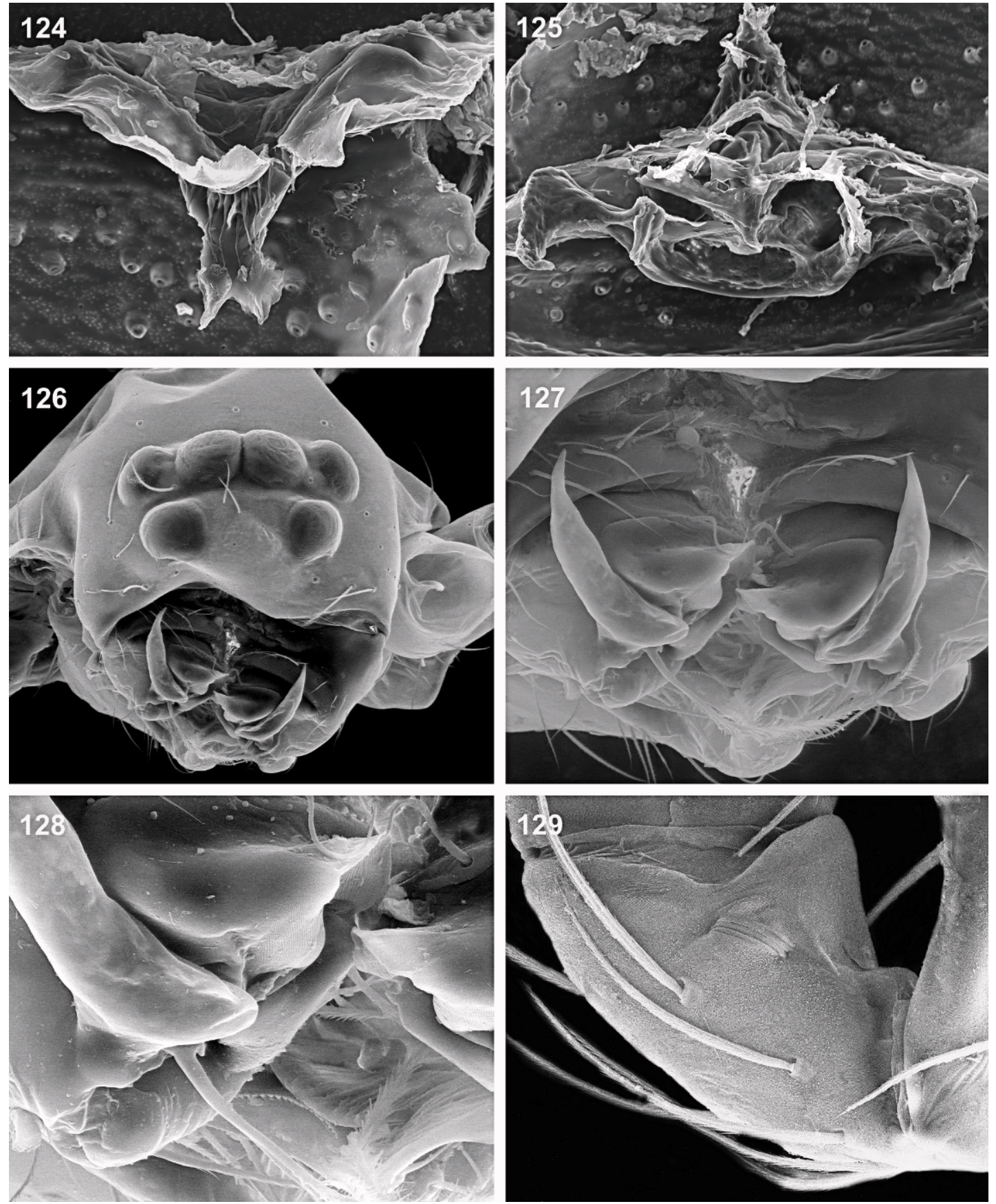

Figs. 124-129. 124-125, Predatoroonops billy, n. sp., female internal genitalia, dorsal view: 124, anterior receptaculum; 125, posterior receptaculum, dorsal view. 126-129, P. valverde, n. sp., male: 126, carapace and chelicerae, frontal view; 127-128, chelicerae; 127, distal and subdistal apophysis, frontal view; 128, detail of base of distal and subdistal apophysis, frontal view; 129, patela of male palp with liriform organ, prolateral view. 

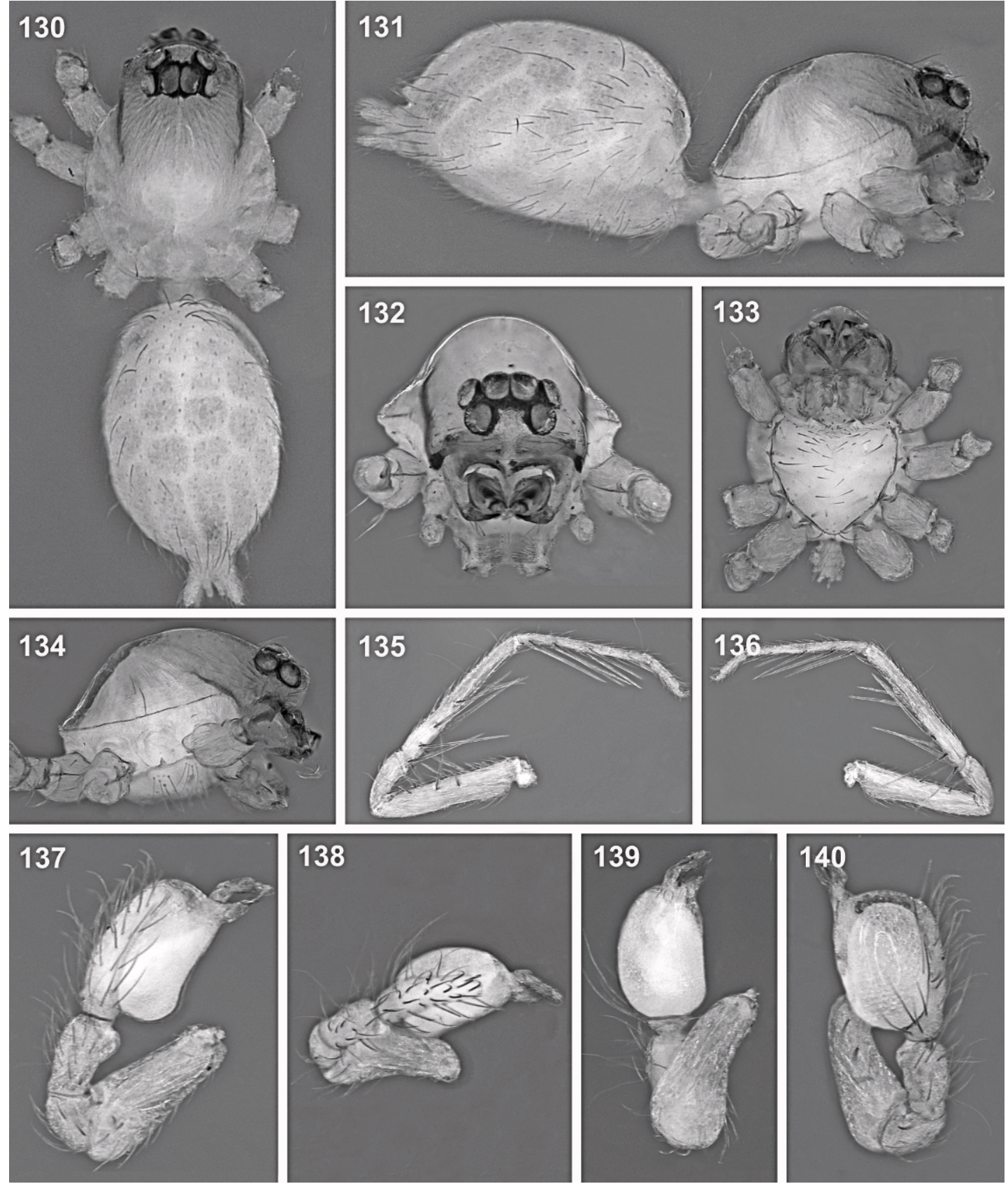

Figs. 130-140. Predatoroonops valverde, n. sp., male. 130-131, Body: 130, dorsal view; 131, lateral view. 132-134, Carapace. 132, Frontal view. 133, Ventral view. 134, Lateral view. 135-136, Leg I, 135, Retrolateral view. 136, Prolateral view. 137-140, Palp. 137, Prolateral view. 138, Dorsal view. 139, Ventral view. 140, Retrolateral view. 

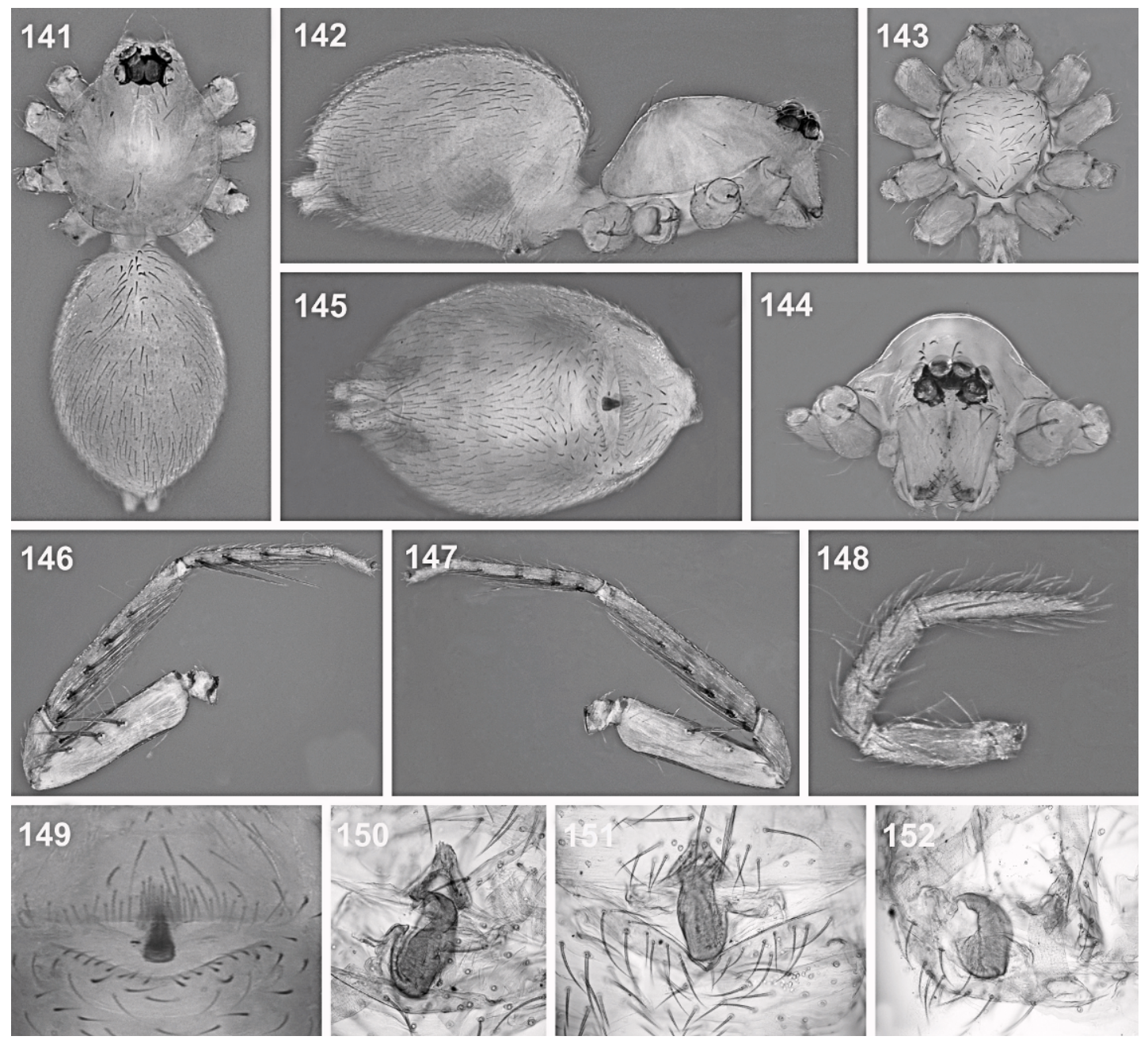

Figs. 141-152. Predatoroonops valverde, n. sp., female. 141-142, Body: 141, dorsal view; 142, lateral view. 143-144, Carapace: 143, ventral view; 144, frontal view. 145, Abdomen, ventral view. 146-147, Leg I: 146, prolateral view; 147, retrolateral view. 148, Pedipalp, prolateral view. 149-152, Internal genitalia: 149, ventral view; 150, dorsal view by transparence; 151, ventral view, cleared; 152, lateral view, cleared.

Predatoroonops poncho Brescovit, Rheims, and Ott, new species

Figures 14, 66-67, 72-102; map 4

TYPES: Male holotype and female paratype from Parque Nacional da Serra dos Órgãos, $22^{\circ} 27^{\prime} \mathrm{S}, 42^{\circ} 59^{\prime} \mathrm{W}$, Teresópolis, Rio de Janeiro, Brazil (Jul. 18-22, 2001, Equipe Biota) deposited in IBSP 135880 (PBI_OON 11182).

ETYMOLOGY: The specific name is a nickname for Jorge "Poncho" Ramirez, played by Richard Chaves in the movie "Predator"; Poncho is a Chicano who speaks fluent Spanish and shows a sarcastic wit.
Diagnosis: Males of Predatoroonops poncho resemble those of $P$. schwarzeneggeri, $P$. billy, and $P$. valverde by the presence of a curved distal apophysis in the chelicerae (figs. 13, 15-16). It can be distinguished from these species by the shorter distal apophysis and very large subdistal furrow (fig. 14). Females can be easily distinguished from those of the remaining species of the genus by the short distal cylindrical area of the anterior receptaculum and Z-shaped apodema plate with apodema process in the female epigynum (fig. 66). 

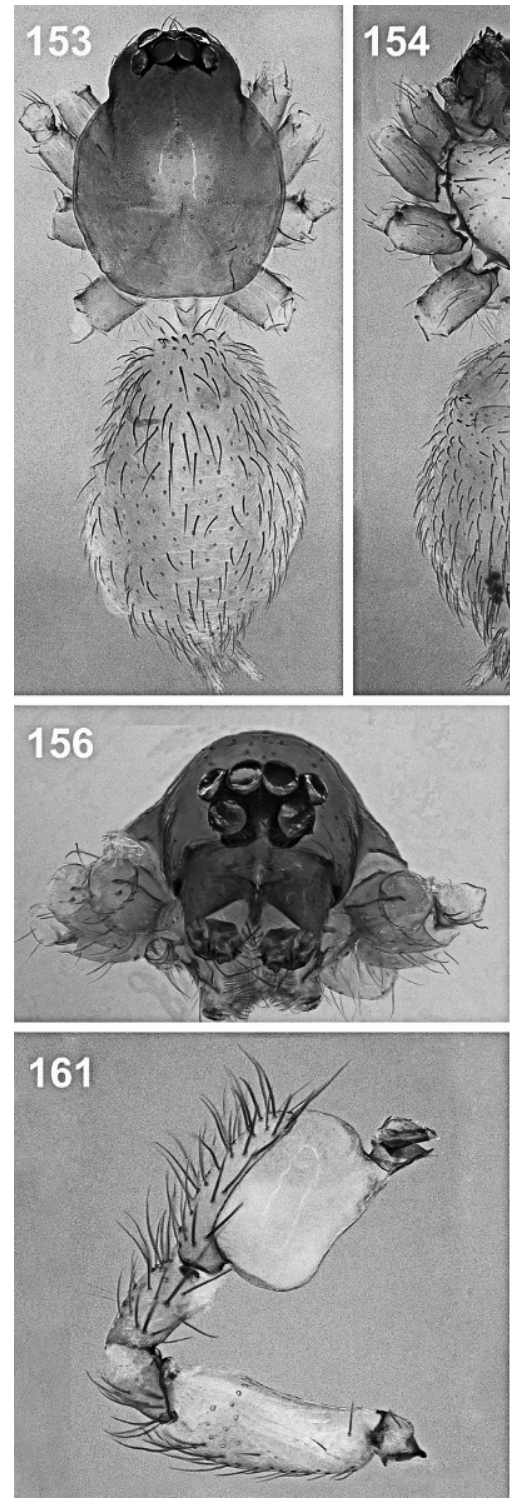
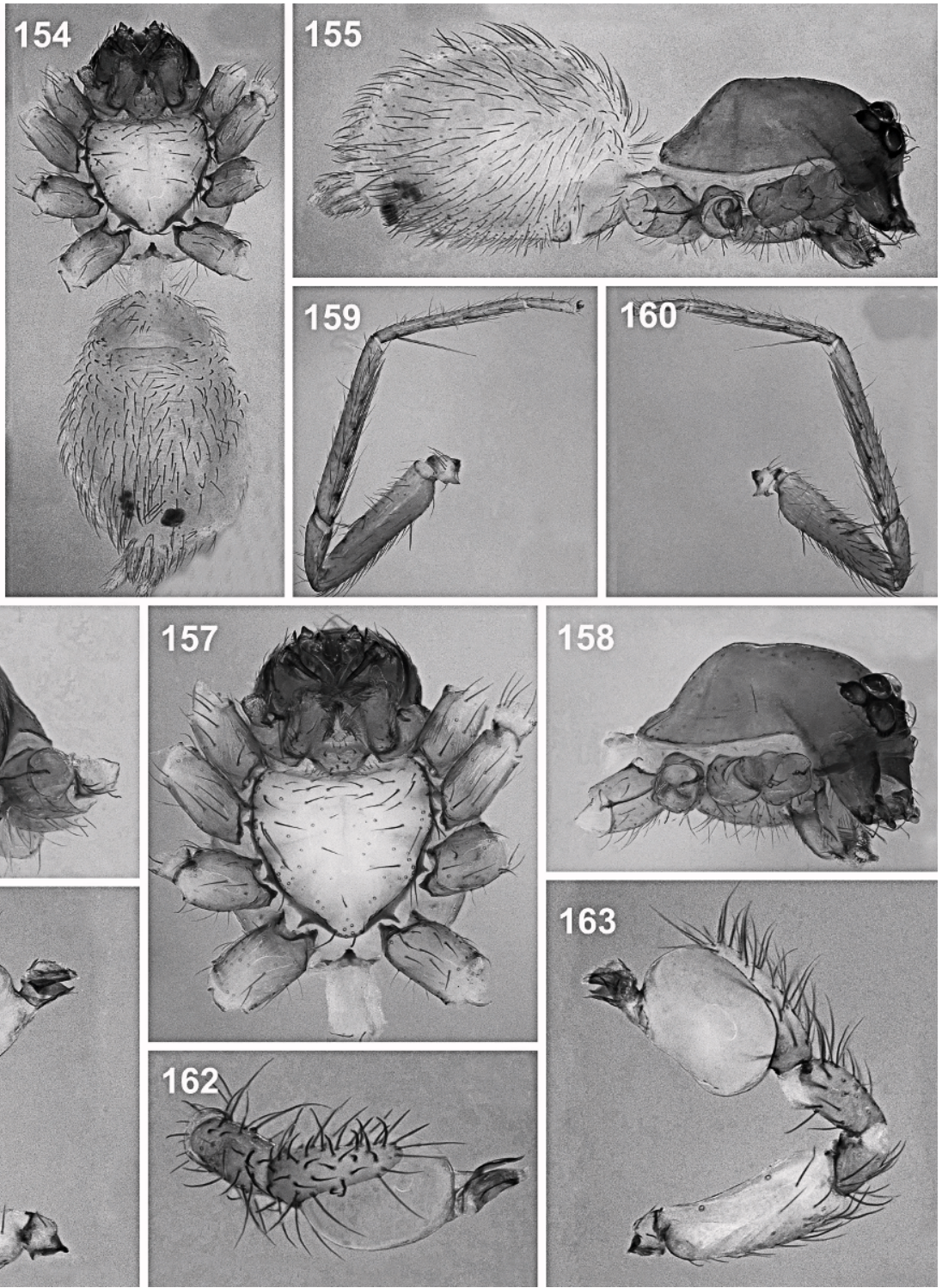

Figs. 153-163. Predatoroonops blain, n. sp., male. 153-155, Body: 153, dorsal view; 154,ventral view; 155, lateral view. 156-158, Carapace: 156, frontal view; 157, ventral view; 158, lateral view. 159-160, Leg I: 159, retrolateral view; 160, prolateral view. 161-163, Palp: 161, prolateral view; 162, dorsal view; 163, retrolateral view.

Male (PBI_OON_11182): Total length 2.05. Carapace 0.95 long, 0.77 wide. ALE 0.10, PLE 0.10, PME 0.13, ALE-ALE 0.08. Carapace pale orange, without any pattern, anterolateral corners with sclerotized triangular projection (fig. 80). Sternum pale orange. Chelicerae brown, endites, and labium yellow. Clypeus with very small needle- like setae (fig. 14). Chelicerae anterior face with small triangular median furrow, elongated subdistal furrow, stout lateral subdistal apophysis, short distal, dorsally curved apophysis, condylar projection absent (fig. 14). Abdomen dorsum pale white. Legs yellow, femur I 0.85 long. Leg spination: femur I v1-2-2; II d1-0-0; v0-2-2; III-IV d1-0-1; tibia I v2-2-2-2-2, II v2-2-2-2-2, III 

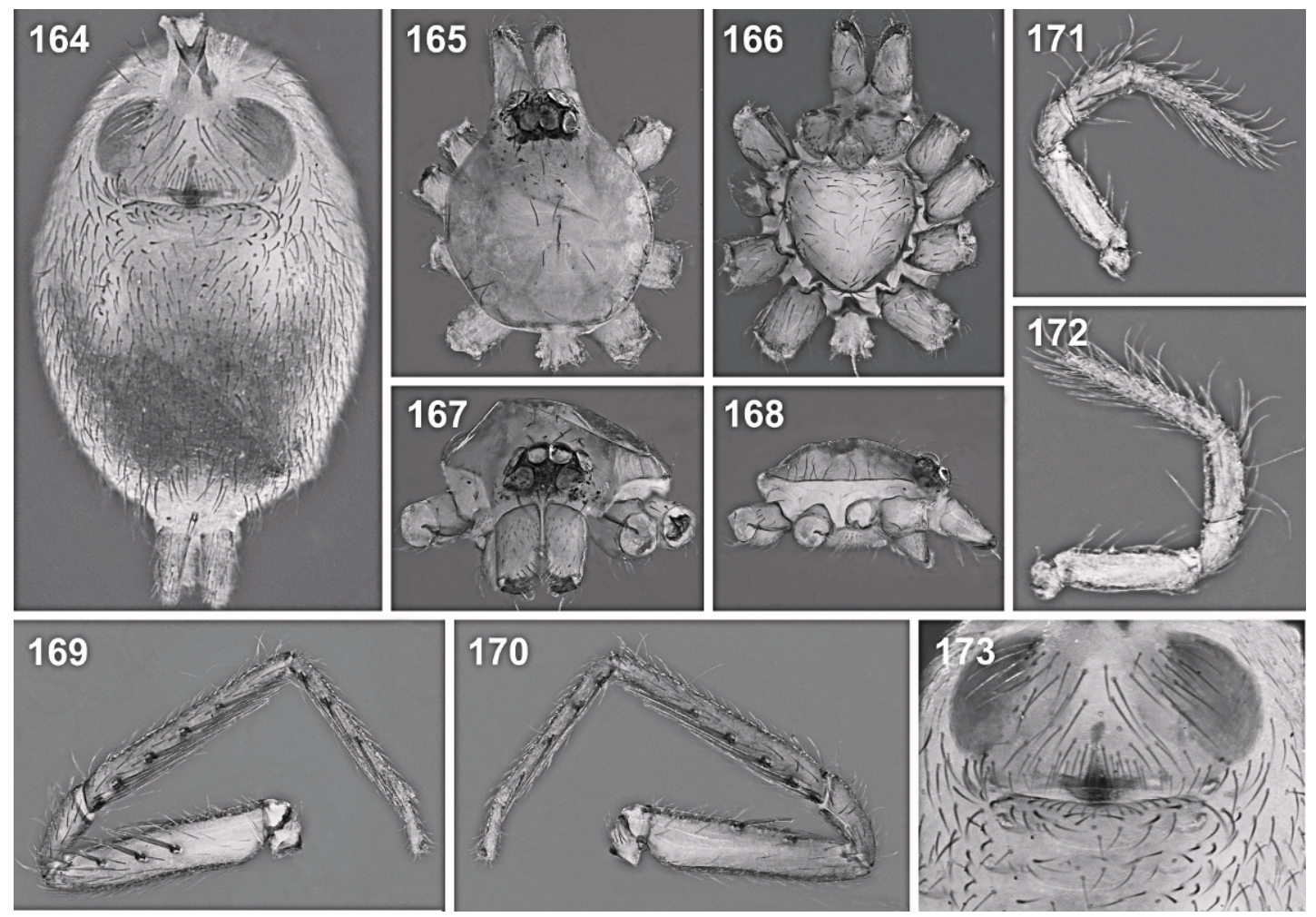

Figs. 164-173. Predatoroonops blain, n. sp., female. 164, Abdomen, ventral view. 165-168, Carapace: 165, dorsal view; 166, ventral view; 167, frontal view; 168, lateral view. 169-170, Leg I: 169, prolateral view; 170, retrolateral view. 171-172, Pedipalp: 171, retrolateral view. 172, prolateral view. 173, Internal genitalia, ventral view.

d0-1-0; p1-1-0; v0-1-0; IV d0-1-0; p0-1-1; v0$1-2$; $\mathrm{r} 0-1-1$; metatarsus I v2-2-2-2, II v2-2-22 , III d0-0-1; v0-0-2; r1-1-0; IV d0-1-1; p0-11; v0-1-2; r0-1-1. Male palp proximal segments pale orange; cymbium yellow, bulb white with truncate base (figs. 86, 89); slender hyaline process with large base (fig. 86).

FeMALE (PBI_OON_11182): Total length 2.35. Carapace 0.90 long, 0.75 wide. ALE 0.10, PLE 0.10, PME 0.12, ALE-ALE 0.08. Abdomen dorsum white. Legs: femur I 0.73 long. Internal genitalia, when connected, with hat-shaped anterior receptaculum (figs. 66, 102) and globose posterior receptaculum (figs. 66-67), when separated, presents a conical tip (figs. 100-101); Z-shaped apodema plate with short apodema process (figs. 66-67, 100-101).

OTHER MATERIAL EXAMINED: BRAZIL: Rio de Janeiro: Teresópolis, Parque Nacional da Serra dos Órgãos, $22^{\circ} 27^{\prime} \mathrm{S}, 42^{\circ} 59^{\prime} \mathrm{W}$ Jul. 18-22, 2001, pitfall (Equipe Biota, IBSP 135874-135891, PBI_OON 11129, 1117811184, 11831-11839), 18 के 8 우.

DisTRIBUTION: Known only from the state of Rio de Janeiro, Brazil (map 4).

Predatoroonops billy Brescovit, Rheims, and Ott, new species

Figures 11-12, 15, 68-69, 103-125; map 1

TYPES: Male holotype and female paratype from Floresta da Cicuta, $22^{\circ} 24^{\prime}-22^{\circ} 38^{\prime} \mathrm{S}$, $44^{\circ} 09^{\prime}-44^{\circ} 20^{\prime} \mathrm{W}$, Volta Redonda, Rio de Janeiro, Brazil (Jun. 11-18, 2001, Equipe Biota), deposited in IBSP 136097 (PBI_OON 11174).

ETYMOLOGY: The specific name is a nickname for Billy Sole, played by Sonny Landham. In "Predator," Billy is a Native American tracker.

Diagnosis: Males de Predatoroonops billy resemble those of $P$. schwarzeneggeri and $P$. 

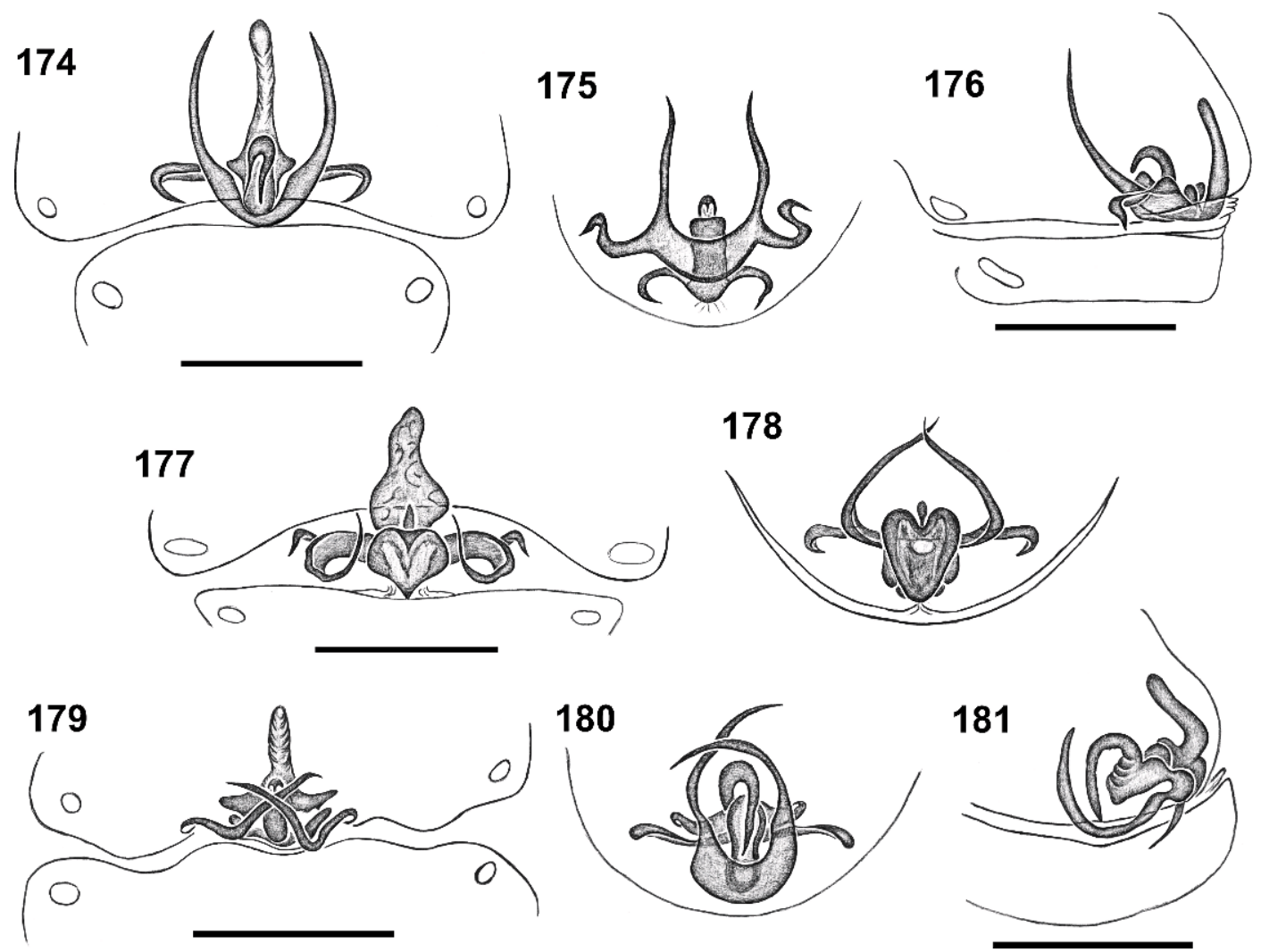

180

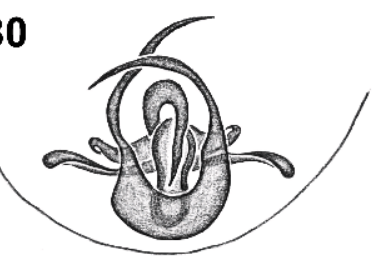

181

182

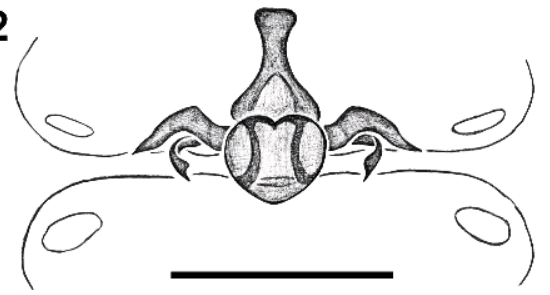

183

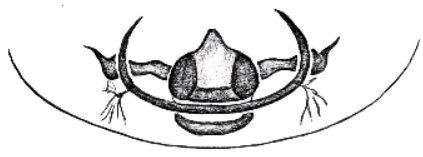

Figs. 174-183. Predatoroonops species, female internal genitalia; 174-176, Predatoroonops blain, n. sp.: 174, dorsal view; 175, posterior view; 176, lateral view. 177-178, P. maceliot, n. sp.: 177, dorsal view; 178, posterior view. 179-181, P. anna, n. sp.: 179, dorsal view; 180, posterior view; 181, lateral view. 182-183, $P$. rickhawkins, n. sp.: 182, dorsal view; 183, posterior view.

valverde by the presence of long, distal dorsally curved apophysis in the chelicerae (figs. 13, 16) but can be separated from them by the larger subdistal apophysis, subdistal furrow (fig. 15). Females can be easily distinguished from those of the remaining species of the genus by the subtriangular, wrinkled anterior receptaculum, distally rounded posterior receptaculum, apodema process enlarged at the extremities (fig. 68).
Male (PBI_OON_11174): Total length 1.75. Carapace 0.87 long, 0.70 wide. ALE 0.10, PLE 0.10, PME 0.12, ALE-ALE 0.08. Carapace yellow, with brown stripe along margin of cephalic area, anterolateral corners with slightly sclerotized triangular projections (fig. 106). Sternum yellow. Chelicerae, endites, and labium orange. Clypeus with very small needlelike setae (fig. 15). Chelicerae anterior face with short triangular 

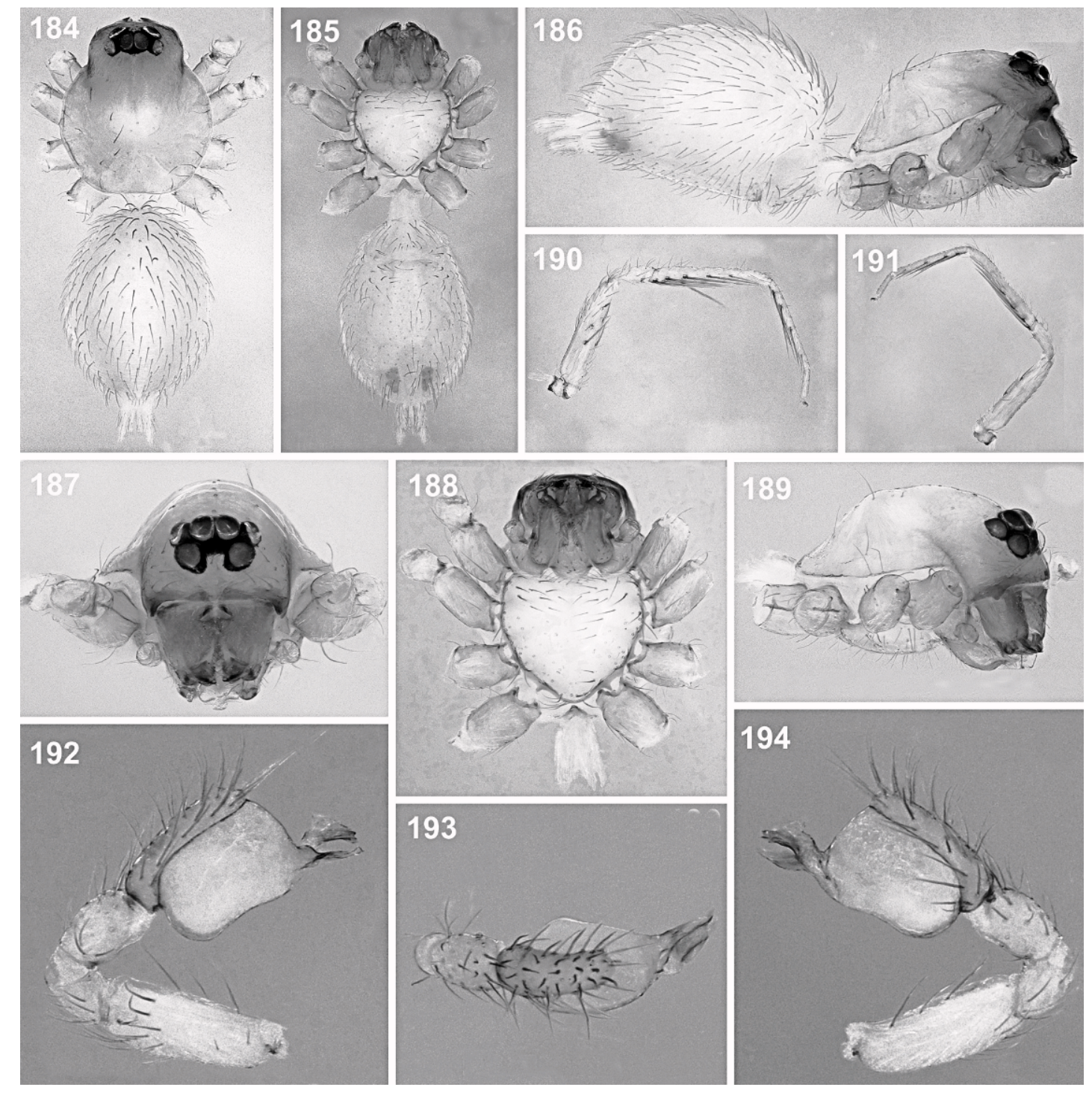

Figs. 184-194. Predatoroonops maceliot, n. sp., male. 184-186, Body: 184, dorsal view; 185,ventral view; 186, lateral view. 187-189, Carapace: 187, frontal view; 188, ventral view; 189, laterofrontal view. 190-191, Leg I: 190, retrolateral view; 191, prolateral view. 192-194, Palp: 192, prolateral view; 193, dorsal view; 194, retrolateral view.

median furrow, elongated subdistal furrow, stout, sclerotized lateral subdistal apophysis, long, distally upcurved apophysis; condylar projection absent (fig. 15). Abdomen dorsum pale orange. Legs yellow, femur I 0.75 long. Leg spination: femur: I v1-2-2; II v0-2-2; IIIIV d1-0-1; tibia I v2-2-2-2-2, II v2-2-2-2-2, III d0-1-0; p0-1-0; v0-1-2; r0-1-1; IV d0-1-0; p0-
1-1; v0-1-2; r0-1-1; metatarsus I v2-2-2-2, II v2-2-2-2, III v0-1-2; r0-1-1; IV p0-1-1; v0-1-2; r0-1-1. Male palp proximal segments yellow; cymbium yellow; bulb white, long laminar hyaline process (figs. 109, 111).

FEMALE (PBI_OON_11174): Total length 2.08. Carapace 0.90 long, 0.75 wide. ALE 0.10, PLE 0.10, PME 0.12, ALE-ALE 0.08. 

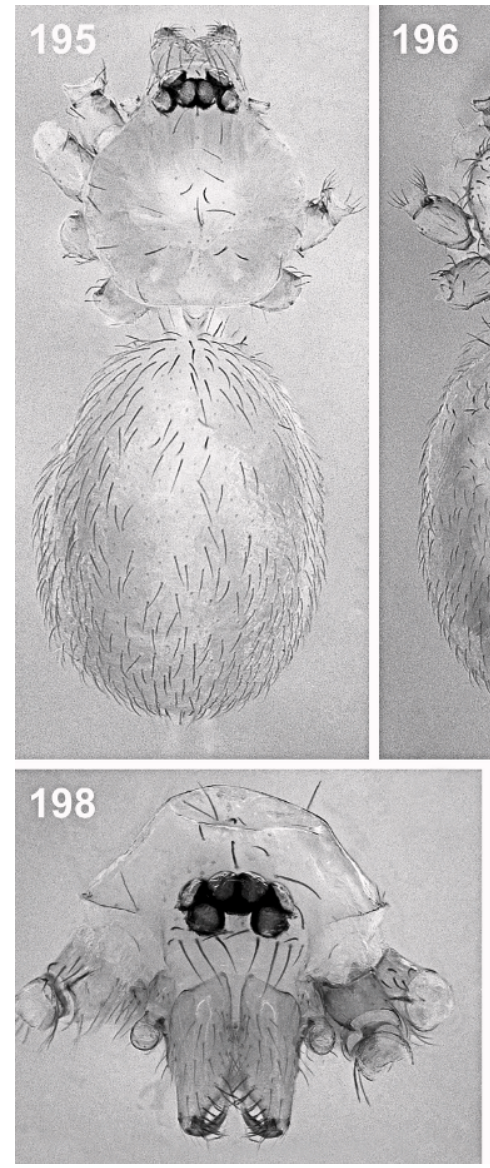
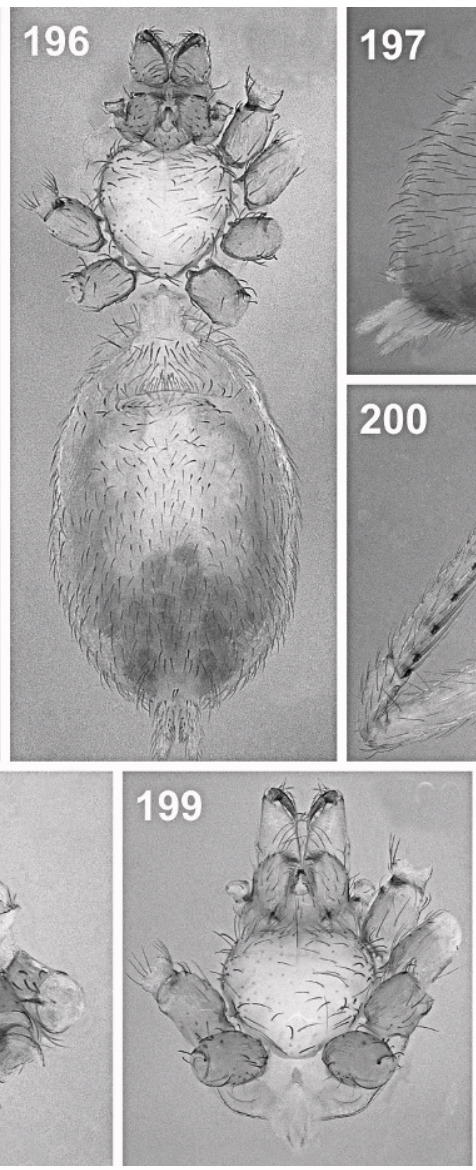
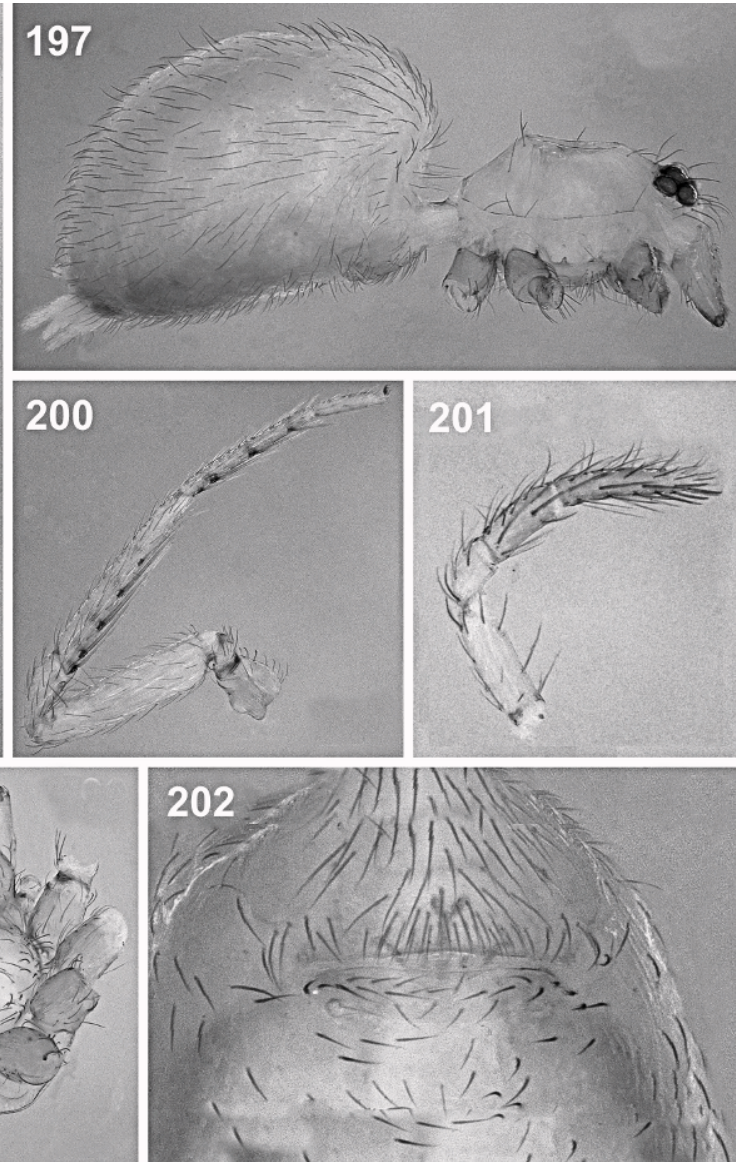

Figs. 195-202. Predatoroonops maceliot, n. sp., female. 195-197, Body: 195, dorsal view; 196, ventral view; 197, lateral view. 198-199, Carapace: 198, frontal view; 199, ventral view. 200, Leg I, retrolateral view. 201, Pedipalp, retrolateral view. 202, Internal genitalia, ventral view.

Chelicerae, endites, and labium pale orange. Abdomen dorsum orange. Leg: femur I 0.73. Leg spination: femur I v1-2-2; II v0-2-2; IIIIV d1-0-1; tibia I v2-2-2-2-2, II v2-2-2-2-2, III d0-1-0; p0-1-1; v0-0-1; r0-1-1; IV d0-1-0; p0-11 ; v0-1-2; r0-1-1; metatarsus I v2-2-2-2, II v22-2-2, III v0-1-1; r0-1-1, IV p0-1-1; v0-1-2; r01-1. Internal genitalia with short; triangular anterior receptaculum and short and rounded posterior receptaculum (figs. 68-69, 122123); apodema plate curved, narrowed distally, with elongated apodema process, enlarged at extremities (figs. 68, 122-125).

OTHER MATERIAL EXAMINED: BRAZIL: Rio de Janeiro: Volta Redonda, Floresta da Cicuta, $22^{\circ} 24^{\prime}-22^{\circ} 38^{\prime} \mathrm{S}, 44^{\circ} 09^{\prime}-44^{\circ} 20^{\prime} \mathrm{W}$, pitfall, Jun. 11-18, 2001 (Equipe Biota, IBSP
136071-136102, PBI_OON 11150-11177), 18 ơ 16; Paraíba do Sul, Fazenda Maravilha, $22^{\circ} 12^{\prime} \mathrm{S}, 43^{\circ} 16^{\prime} \mathrm{W}$, March 17-21, 2001, pitfall, (Equipe Biota, IBSP 136644, PBI_ OON 11149), 1 sో.

DisTRIBUTION. Known only from the state of Rio de Janeiro, Brazil (map 1).

\section{Predatoroonops valverde Brescovit, Rheims,} and Ott, new species

Figures 8, 16, 70-71, 126-152; map 1

TyPES: Male holotype and female paratype from Enseada das Palmas, Ilha Grande, $23^{\circ} 8^{\prime} 26^{\prime \prime} \mathrm{S}, 44^{\circ} 14^{\prime} 50^{\prime} \mathrm{W}$, Angra dos Reis, Rio de Janeiro, Brazil (Feb. 2-12, 1997, M. Ramirez), deposited in IBSP 133531 (PBI_OON_11077). 

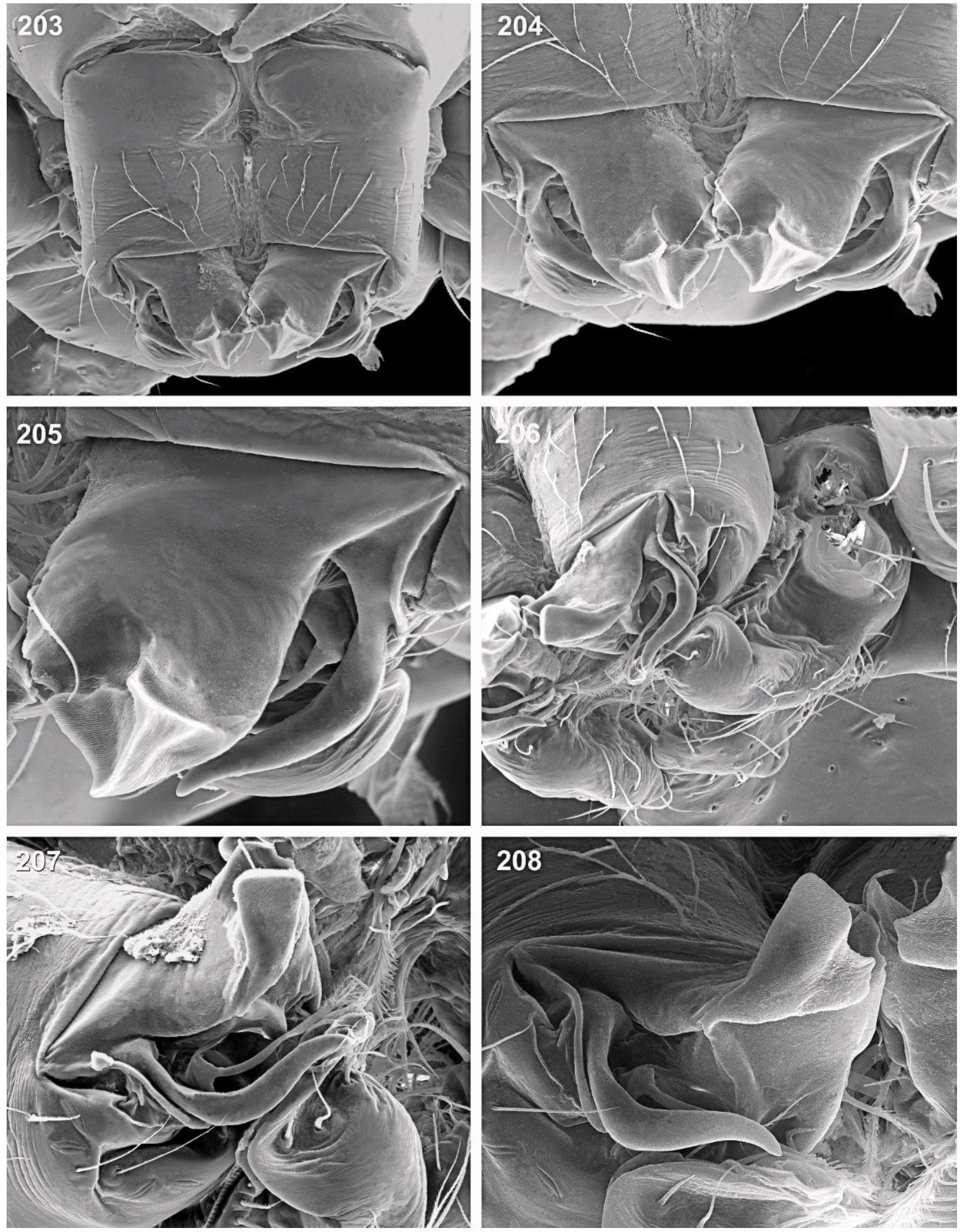

Figs. 203-208. Predatoroonops anna, n. sp., male chelicerae. 203, Frontal view. 204, Distal and subdistal apophysis, frontal view. 205-208, Details of left distal and subdistal apophysis: 205, frontal view; 206, lateral view; 207-208, anterior view. 
ETYMOLOGY: The specific name refers to the South/Central American country Val Verde, a fictional country created for "Predator" by Hollywood filmmakers, to avoid getting into legal or diplomatic disputes.

Diagnosis: Males of Predatoroonops valverde resemble those of $P$. schwartzaneggeri and $P$. billy by the presence of a long, dorsally curved distal apophysis in the chelicerae (figs. 13, 15) but can be separated from these species by the longer subdistal furrow, short subdistal apophysis (figs. 16, 132). Females can be easily distinguished from those of the remaining species by the triangular anterior receptaculum, cylindrical posterior receptaculum with slender tip (figs. 70-71, 150-152).

MALE (PBI_OON_11077): Total length 1.95. Carapace 0.90 long, 0.75 wide. ALE 0.10, PLE 0.10, PME 0.12, ALE-ALE 0.08. Carapace pale orange, without any pattern, anterolateral corners with slightly sclerotized triangular projections (fig. 134). Sternum, chelicerae, endites, and labium yellow. Clypeus with very small needlelike setae (fig. 16). Chelicerae anterior face with long, recurved triangular median furrow, short subdistal narrow furrow, narrowed lateral subdistal apophysis, long dorsally curved distal apophysis and condylar projection absent (fig. 16). Abdomen dorsum white. Legs yellow, femur I 0.80. Leg spination: femur: I v2-2-1; II v2-20 ; III d1-1-0, tibia I v2-2-2-2-2, II v2-2-2-2-2, III v0-1-1; IV p1-0-0; v0-1-1; r1-1-0; metatarsi I v2-2-2-2, II v2-2-2-2, III v1-2-2; IV p0-0-1; $\mathrm{v} 0-1-2 ; \mathrm{r} 0-0-1$. Male palp proximal segments white; cymbium yellow; bulb white; large slender hyaline process (fig. 137).

FeMALE (PBI_OON_11077): Total length 2.10. Carapace 0.95 long, 0.82 wide. ALE 0.10, PLE 0.10, PME 0.12, ALE-ALE 0.06. Abdomen dorsum pale white. Legs: femur I 0.75. Leg spination: femur I v2-2-1; II v2-2-0; III d1-1-0, tibia I v2-2-2-2-2, II v2-2-2-2-2, III-IV v0-1-1; metatarsus I v2-2-2-2, II v2-22-2, III v0-1-2; IV p1-1-0; v0-1-0; r1-1-0. Internal genitalia with triangular anterior receptaculum and posterior receptaculum with slender tip (figs. 70-71, 150-152); elongated apodema plate flattened, not enlarged laterally, with small and globose apodema process (figs. 70-71).

Other MATERIAl EXAMINED: BRAZIL: Rio de Janeiro: Angra dos Reis, Ilha Grande, $23^{\circ} 8^{\prime} 26^{\prime \prime} \mathrm{S}, 44^{\circ} 14^{\prime} 50^{\prime \prime} \mathrm{W}$, Enseada das Palmas, Feb. 2-12, 1997 (MACN, PBI_OON_11079),

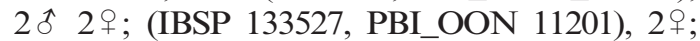
(IBSP 133533, PBI_OON 11203), $1 \hat{\delta}$; (IBSP 133530, PBI_OON 11076), 1우 (IBSP 133528, PBI_OON 11202), 1 s ; (IBSP 133529, PBI_OON $11075,1 \hat{\delta} 1$ ㅇ), all collected by M. Ramirez.

DisTRIBUTION: Known only from the type locality in the state of Rio de Janeiro, Brazil (map 1).

Predatoroonops blain Brescovit, Rheims, and Ott, new species

Figures 17, 153-176; map 2

TyPes: Male holotype and female paratype from Parque da Cidade Joventino Silva, $12^{\circ} 59^{\prime} 57^{\prime \prime} \mathrm{S} 38^{\circ} 28^{\prime} 16^{\prime \prime} \mathrm{W}$, Salvador, Bahia, Brazil (Aug. 22-Sept. 03, 2008; C. Queiróz and D. Mendes) deposited in IBSP 125541 (PBI_OON 11097).

ETYMOLOGY: The specific name refers to the character Blain Cooper, played by Jesse Ventura, in the movie "Predator"; he often chews tobacco and wears a battered old slouch hat.

Diagnosis: Males of Predatoroonops blain differ from those of the remaining species by the chelicerae with large, triangular subdistal furrow (figs. 17, 156), short lateral subdistal apophysis short and truncated; short, bifid distal projections (fig. 17). Females can be easily distinguished from those of the remaining species by the very long anterior receptaculum with globose tip, short with sinuous posterior receptaculum (figs. 174 176).

MALE (PBI_OON 10997): Total length 1.99. Carapace 0.90 long, 0.60 wide. ALE 0.10, PLE 0.10, PME 0.12, ALE-ALE 0.06. Carapace orange, without any pattern, anterolateral corners with slightly sclerotized triangular projections (figs. 155, 158). Sternum yellow-brown. Chelicerae, endites, and labium orange-brown. Clypeus with very small needlelike setae (fig. 17). Chelicerae anterior face with small median furrow, subdistal narrow furrow large triangular, lateral subdistal apophysis short and truncated, short and bifid distal projections, condylar projection absent (fig. 17). Abdomen dorsum pale orange. Legs orange, femur I 0.80 long. Leg spination: femur I d1-0-0; v22-1; II d1-0-0; v0-2-2; III d1-0-0; IV d1-0-1; 




Map 2. Distribution of four new Predatoroonops species in southeastern and eastern Brazil: Predatoroonops dillon, P. blain, P. dutch, and P. anna.

tibia I v2-2-2-2-2, II v2-2-2-2-2, III p0-0-1; v0-1-2; r0-0-1; IV p0-1-1; v0-1-2; r0-1-1; metatarsus I v2-2-2-2, II v2-2-2-2, III v0-12; r0-0-1; IV d0-1-0; p0-0-1; v1-0-2; r0-0-1. Male palp proximal segments orange-brown; cymbium pale orange, bulb yellow, slender hyaline process narrow and twisted with laminar hyaline process (figs. 161-163).

FEMALE (PBI_OON_0011097): Total length 2.35. Carapace 0.95 long, 0.75 wide. ALE 0.12, PLE 0.10, PME 0.12, ALE-ALE 0.06. Abdomen dorsum orange. Legs: femur I 0.80 long. Leg spination: femur I v2-2-1; II v0-2-2; III d1-0-0; IV d1-1-0; tibia I v2-2-2-2-2, II v22-2-2-2, III p1-1-0; v0-2-2; r1-1-0; IV p1-1-0; v1-0-2; r1-1-0; metatarsus I v2-2-2-2, II v2-22-2, III v0-1-1; r1-1-0; IV d0-1-0; p1-1-1; v1-02 ; r-1-1. Internal genitalia with very long anterior receptaculum with globose tip and short and sinuous posterior receptaculum (figs. 174-176); long and semicircular apodema plate with elongated and sinuous apodema process (figs. 175-176).

Other MATERIAL EXAMINED: BRAZIL: Bahia: Salvador, Parque da Cidade Joventino
Silva, $12^{\circ} 58^{\prime} 60 \mathrm{~S}, 38^{\circ} 31^{\prime} \mathrm{W}$, Aug. 22-Sept. 03, 2008, pitfall (C. Queiróz and D. Mendes, IBSP 125537-125540, PBI_OON 1109111092, 11094, 11096; IBSP 125542-125543, PBI_OON 11093, 11095), 7 ô 1 우 ; Cachoeira, Comunidade de São Francisco de Paraguaçu, Reserva de Peninha, $13^{\circ} 45^{\prime} 0 \mathrm{~S}, 40^{\circ} 12^{\prime} 0 \mathrm{~W}$, pitfall (M. Peres et al., IBSP 120280, PBI_ OON 10997), $1 \delta$.

Distribution. Known only from the state of Bahia, Brazil (map 2).

Predatoroonops maceliot Brescovit, Rheims, and Ott, new species

Figures 18, 177-178, 184-202; map 4

TYPES: Male holotype and female paratype from Parque Estadual de Ilhabela (23 $50^{\prime} 53^{\prime \prime} \mathrm{S}$ $\left.45^{\circ} 20^{\prime} 54^{\prime \prime} \mathrm{W}\right)$, Ilhabela, São Paulo, Brazil (Oct. 9-15, 2001, Equipe Biota), deposited in IBSP 57385 and 57382 (PBI_OON 1099510996), respectively.

ETYMOLOGY: The specific name refers to the character Mac Eliot, played by Bill Duke in the movie "Predator"; Mac is a close friend of Blain's and served with him in Vietnam. 

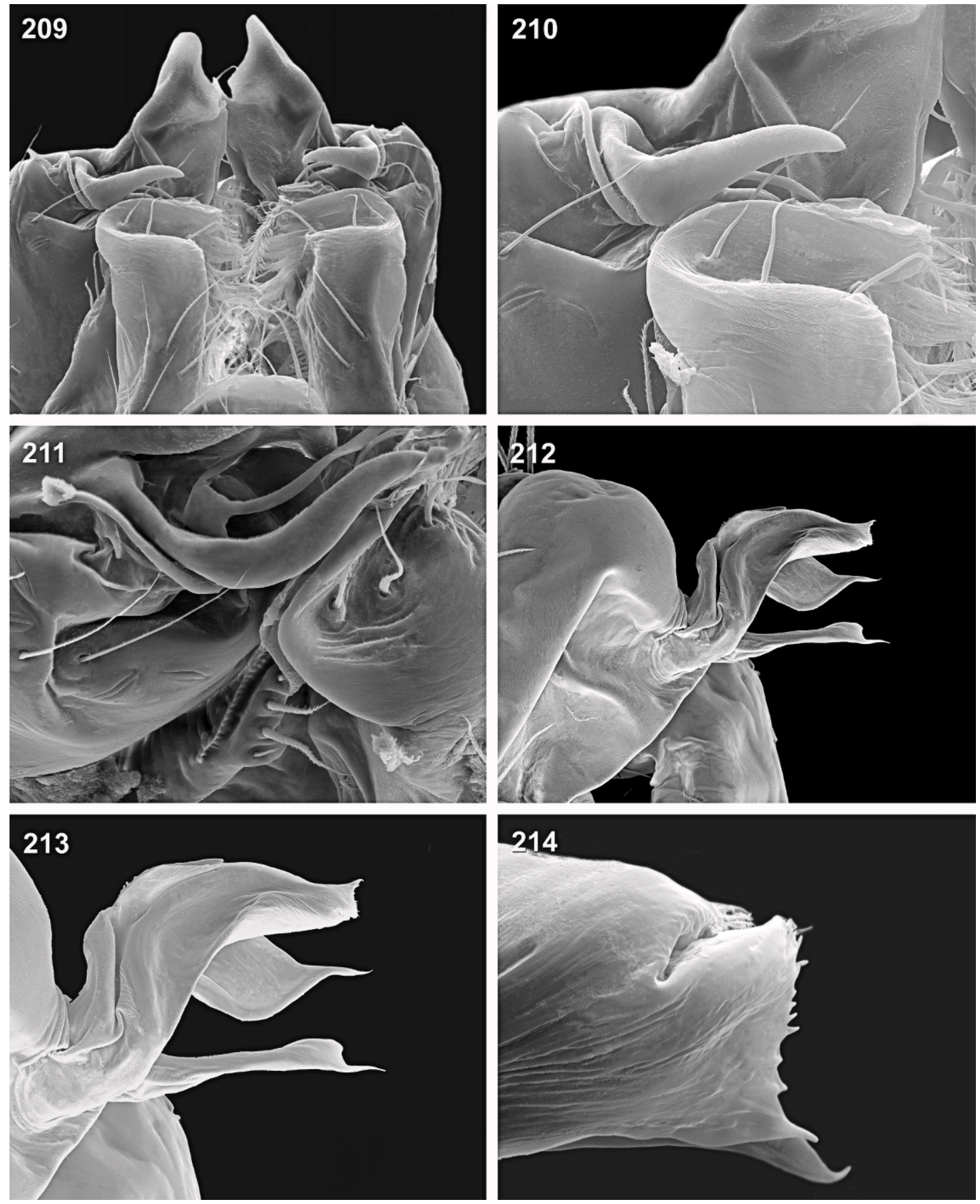

Figs. 209-214. Predatoroonops anna, n. sp. 209-211, Male chelicerae, distal area. 209, Ventral view. 210-211, Details of right distal and subdistal apophysis: 210, ventral view; 211, lateroventral view. 212214, Male palp, prolateral view: 212, distal and subdistal hyaline process; 213, detail of distal and subdistal hyaline process; 214, distal border of laminar hyaline process. 

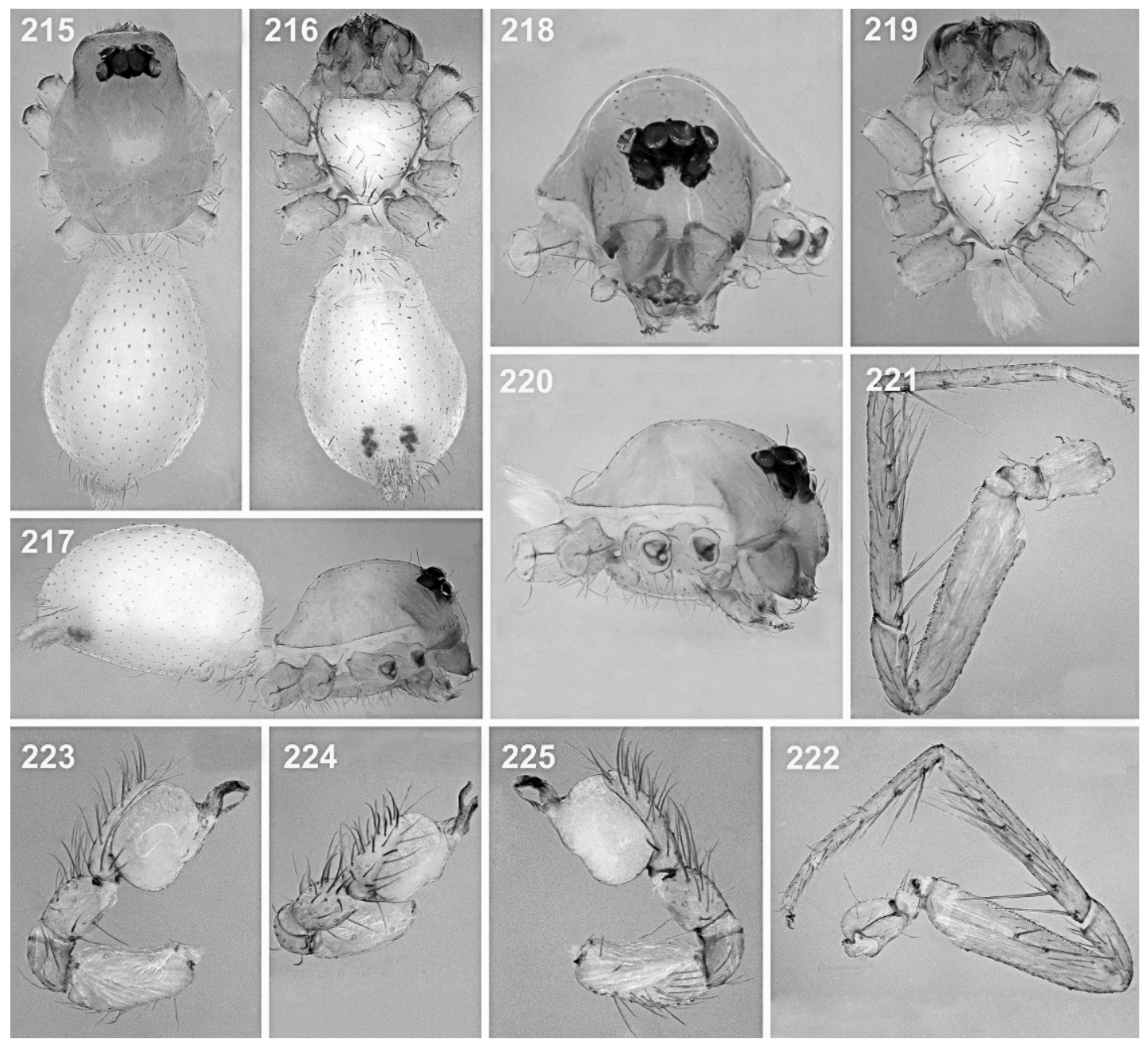

Figs. 215-225. Predatoroonops anna, n. sp., male. 215-217, Body: 215, dorsal view; 216, ventral view; 217, lateral view. 218-220, Carapace: 218, frontal view; 219, ventral view; 220, lateral view. 221-222, Leg I: 221, retrolateral view; 222, prolateral view. 223-225, Palp: 223, retrolateral view; 224, dorsal view; 225, prolateral view.

Diagnosis: Males of Predatoroonops maceliot resemble those of $P$. blain by the small median furrow and by the triangular subdistal furrow. It differs from this species by the much smaller subdistal furrow, subdistal and distal apophysis with distal area truncated apically (fig. 18), without bifid apophysis. Females can be easily distinguished from those of the remaining species by the cordiform posterior receptaculum with a short distal projection, apodema plate with twisted tip (figs. 177-178).
Male (PBI_OON 10995): Total length 1.70. Carapace 0.85 long, 0.60 wide. ALE 0.10, PLE 0.08, PME 0.12, ALE-ALE 0.08. Carapace pale orange, with brown stripe along margin of cephalic area, anterolateral corners with slightly sclerotized triangular projections (figs. 186, 189). Sternum yellow. Chelicerae, endites, and labium pale orange. Clypeus with very small needlelike setae (fig. 18). Chelicerae anterior face with short triangular median furrow, subdistal narrow furrow inconspicuous and triangular, subdistal and distal apophysis 

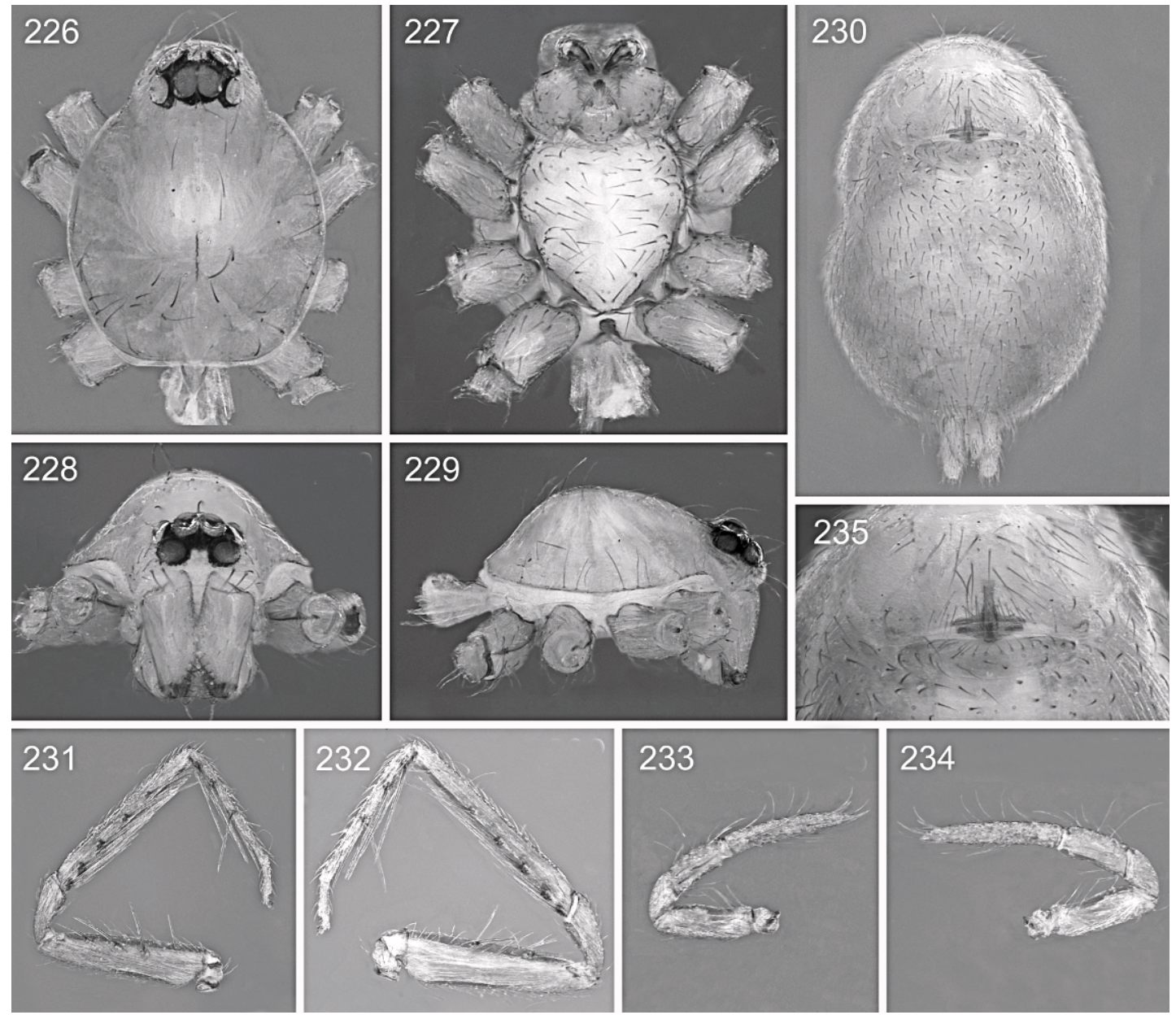

Figs. 226-235. Predatoroonops anna, n. sp., female. 226-229, Carapace: 226, dorsal view; 227, ventral view; 228, frontal view; 229, lateral view. 230, Abdomen, ventral view. 231-232, Leg I: 231, prolateral view; 232, retrolateral view. 233-234, Pedipalp: 233, retrolateral view; 234, prolateral view. 235, Internal genitalia, ventral view.

absent, distal area truncated, subtriangular condylar projection present (fig. 18). Abdomen dorsum white. Legs yellow, femur I 0.70 long. Leg spination: femora: I-II v2-2-1; III-IV d1-00 ; tibiae I v2-2-2-2-2, II v2-2-2-2-2, III d0-1-0; p0-0-1; v0-2-2; r0-0-1; IV d0-1-0; p1-1-0; v0-1-2; r1-1-0; metatarsus I v2-2-2-2, II v2-2-2-2, III v0-2-2; IV p0-0-1; v0-1-2; r0-0-1. Male palp proximal segments yellow; cymbium yellow; bulb white, slender hyaline process with conspicuous base (fig. 192).

Female (PBI_OON 10996): Total length 2.08. Carapace 0.75 long, 0.55 wide. ALE 0.08, PLE 0.08, PME 0.10, ALE-ALE 0.06. Abdomen dorsum white. Legs: femur I 0.62 long. Leg spination: femora: I p0-1-1; v0-0-1; II p0-1-1; v2-2-1; III d1-1-0; IV d1-0-1; tibia I v2-2-2-2-2, II v2-2-2-2-2, III d0-0-1; p0-1-1; v0-1-1; r0-0-1; IV d0-1-0; p0-1-1; v1-1-2; metatarsus I v2-2-2-2, II v2-2-2-2, III v2-01; r1-1-0; IV p0-1-1; v1-1-2; r0-0-1. Internal genitalia with compact anterior receptaculum and cordiform posterior receptaculum with a short distal projection; long and sinuous apodema plate with twisted tip and short and curved apodema process (figs. 177-178).

OTHER MATERIAL EXAMINED: BRAZIL: Rio de Janeiro: Rio de Janeiro, Parque Nacional da Tijuca, $22^{\circ} 56^{\prime} 17^{\prime \prime} \mathrm{S} 43^{\circ} 13^{\prime} 52^{\prime \prime}$. Vale da Piedade, Gávea, Jan. 18, 2005 (D.R. 



Figs. 236-245. Predatoroonops rickhawkins, n. sp., male. 236-237, Body: 236, dorsal view; 237, lateral view. 238-240, Carapace: 238, frontal view; 239, ventral view; 240, lateral view. 241-242, Leg I: 241, retrolateral view; 242, prolateral view. 243-245, Palp: 243, prolateral view; 244, ventral view; 245, retrolateral view. 
Pedroso, MNRJ 6176, PBI_OON 11854), 1 §ิ 1\%; Gávea, Jan. 18, 2005 (O. Villareal, MNRJ 6202, PBI_OON 11852), 1 우 Morro do Archer, Jan. 19, 2005 (T.S. Moreira, MNRJ 6206, PBI_OON 11853), 1 ㅇ; Morro do Archer, Jan. 19, 2005 (D.R. Pedroso, MNRJ 6208, PBI_OON 11855), 1 ㅇ.

DisTRIBUTION: Known only from the states of São Paulo and Rio de Janeiro, Brazil (map 4).

Predatoroonops anna Brescovit, Rheims, and Bonaldo, new species

Figures 2, 5-7, 19, 179-181, 203-235; map 2

TYPES: Male holotype and female paratype from Lafaiete Coutinho $\left(13^{\circ} 39^{\prime} 21^{\prime \prime} \mathrm{S}\right.$, $40^{\circ} 12^{\prime} 46^{\prime \prime} \mathrm{W}$ ), Bahia, Brazil, pitfall (Jun. 2006-Jul. 2007, J. Romão), deposited in IBSP 92714, PBI_OON 10988 and IBSP 98848, PBI_OON 11103, respectively.

ETYMOLOGY: The specific name refers to the character Anna, played by Elpidia Carrilo in the movie "Predator"; Anna is one of the guerrillas captured by Dutch's troops and she survives the death of the Predator.

Diagnosis: Males of Predatoroonops anna differ from those of the remaining species by the narrow and elongated subdistal furrow and the short subdistal apophysis that is curved dorsally at its distal end (fig. 19). Females can be easily distinguished from those of the remaining species by the elongated, folded anterior receptaculum, with large base, apodema plate with extremities anteriorly crossed over each other (figs. 180-181).

Male (PBI_OON 10988): Total length 1.90. Carapace 0.90 long, 0.70 wide. ALE 0.12, PLE 0.10, PME 0.12, ALE-ALE 0.06. Carapace pale orange, with brown stripe along margin of cephalic area, anterolateral corners with slightly sclerotized triangular projections (figs. 217, 220). Sternum yellow. Chelicerae, endites, and labium orangebrown. Clypeus with very small needlelike setae (fig. 19). Chelicerae anterior face with short triangular median furrow, elongated subdistal narrow furrow (figs. 203-205), subdistal apophysis short, curving upward; elongated and very narrow distal apophysis (figs. 206-211) and condylar projection absent (fig. 19). Abdomen dorsum pale orange. Legs orange, femur I 0.80 long. Leg spina- tion: femur: I d1-0-1; v0-1-1; II d1-0-0; III-IV d1-0-1; tibia I v2-2-2-2-2, II v2-2-2-2-2, III d0-1-0; p1-1-0; v0-1-0; r0-1-0; IV d0-1-0; p01-1; v0-1-1; r0-1-1; metatarsus I v2-2-2-2, II v2-2-2-2, III v0-0-2; r0-1-1; IV d0-1-0; p0-1-1; $\mathrm{v} 0-1-2 ; \mathrm{r} 0-1-1$. Male palp proximal segments yellow-brown; cymbium pale orange, bulb yellow, hyaline process slender, very narrow (figs. 212-214; 223-225).

Female (PBI_OON 11103): Total length 2.25. Carapace 0.93 long, 0.76 wide. ALE 0.10, PLE 0.10, PME 0.12, ALE-ALE 0.08. Carapace without any pattern. Abdomen dorsum orange. Legs: femur I 0.75 long. Leg spination: femur I d01-1; v1-2-2; II d0-1-1; v0-2-2; III-IV d0-1-1; tibia I v2-2-2-2-2, II v2-2-2-2-2, III d0-1-0; p0-1-0; v0-1-1; IV d0-1-0; p1-0-0; v0-1-2; r1-0-0; metatarsus I v2-22-2: II v2-2-2-2, III v0-1-1; r1-1-0; IV d1-1-0; p1-10 ; v0-1-2; r1-1-0. Internal genitalia with elongated and curved anterior receptaculum, with large base, and short posterior receptaculum with process elongated anteriorly; apodema plate very long with extremities anteriorly crossed over each other, short apodema process (figs. 180-181).

OTHER MATERIAL EXAMINED: BRAZIL: Bahia: Lafaiete Coutinho, $13^{\circ} 39^{\prime} 21^{\prime \prime} \mathrm{S}, 40^{\circ} 12^{\prime} 46^{\prime} \mathrm{W}$, Jun. 2006-Jul.2007, pitfall (J. Romão, IBSP 92713, PBI OON 10990, 1 $\hat{\delta}$; (IBSP 98869, PBI OON

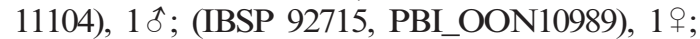
Jequié $\left(13^{\circ} 50^{\prime} 60^{\prime} \mathrm{S}, 40^{\circ} 04^{\prime} 60^{\prime \prime} \mathrm{W}\right)$, Dec. 15-16, 2007 (F.GB. Souza; IBSP 98847, PBI_OON 11101), 1 우 (IBSP 98853, PBI_OON 11112), 1 \% ; (IBSP 98846, PBI_OON 11108), 2\%; (AMNH, ex IBSP 98867, PBI_OON 11102), 18; (AMNH, ex IBSP 98843, PBI_OON 11114), 1 \%; (WAM, ex IBSP 98850, PBI_OON 11098), 1 \% ; (WAM, ex IBSP 98847, PBI_OON 11107), 1웅 (IBSP 98844, PBI_OON 11099), 1 s ; (IBSP 98861, PBI_OON 11116), 1ई ; (IBSP 98862, PBI_OON 11110), $1 \hat{\delta}$; (IBSP 98858, PBI_OON 11111), $1 \delta$; (IBSP 98871, PBI_OON 11030), 18; (IBSP 98851, PBI_OON 11113), 1 ; ; (IBSP 98866, PBI_OON 11029), 1§; (IBSP 98857, PBI_OON 11100), $1 \hat{\delta}$; (IBSP 98874, PBI_OON 11115), $1 \hat{\delta}$.

Distribution. Known only from the state of Bahia, Brazil (map 2).

\section{Predatoroonops rickhawkins Brescovit,} Rheims, and Bonaldo, new species Figures 20, 182-183, 236-256; map 3

TyPES: Male holotype and female paratype from Parque Nacional do Caparaó, 


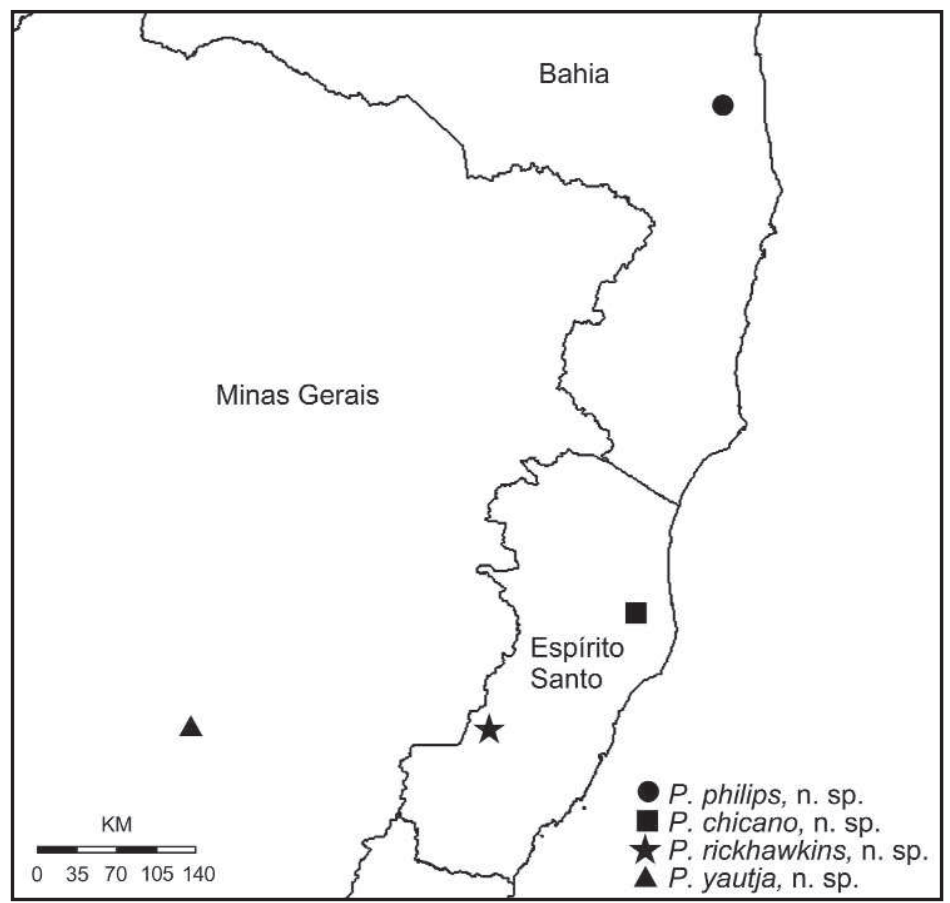

Map. 3. Distribution of four new Predatoroonops species in southeastern and eastern Brazil: Predatoroonops philips, $P$. chicano, P. rickhawkins, and P. yautja.

$41^{\circ} 9^{\prime} \mathrm{W} ; 20^{\circ} 5^{\prime} \mathrm{S}$, Alto Caparaó, Minas Gerais, Brazil (May 01-07, 2002, Equipe Biota), deposited in IBSP 135871 and 135864 (PBI_OON 11840, 11842) respectively.

ETYMOLOGY: The specific name refers to the character Rick Hawkins, played by Shane Black in the movie "Predator"; Rick is the team's radio operator and technical expert, and the first victim of the Predator.

DiAgnOSIS: Males of Predatoroonops rickhawkins differ from those of the remaining species by the high clypeus, two times longer than ALE (fig. 20), extremely small median furrow, very short subdistal projections (fig. 20). Females can be easily distinguished from those of the remaining species by the small cordiform posterior receptaculum, short, with stout apodema plate (fig. 182).

Male (PBI_OON_11840): Total length 1.95. Carapace 0.90 long, 0.77 wide. ALE 0.10, PLE 0.10, PME 0.12, ALE-ALE 0.08. Carapace pale orange, with brown stripe along margin of cephalic area, anterolateral corners with slightly sclerotized triangular projections (figs. 237, 240). Sternum pale orange. Chelic- erae, endites, and labium yellow. Clypeus with very small needlelike setae, two times longer than ALE (fig. 20). Chelicerae anterior face with very small triangular median furrow, long subdistal narrow furrow, inconspicuous lateral subdistal apophysis, short upward-curving distal apophysis; subtriangular condylar projection present (fig. 20). Abdomen dorsum white. Legs yellow, femur I 0.75. Leg spination: femur I d1-0-0; v1-2-2; II d1-0-0; v0-2-2; III-IV d1-0-1; tibia I v2-2-2-2-2, II v2-2-2-2-2, III d0-1-0; p0-1-1; v0-1-1, IV d0-1-0; p1-1-0; v0-1-2; r1-1-0; metatarsus I v2-2-2-2, II v2-2-22, III d0-1-0; v0-1-2; r1-1-0, IV d0-1-0; p1-0-0; v0-1-2; r1-0-0. Male palp proximal segments yellow; cymbium yellow, bulb white, truncated apically, with stout slender hyaline process (figs. 243-245).

Female (PBI_OON_11842): Total length 2.03. Carapace 0.96 long, 0.75 wide. ALE 0.10, PLE 0.10, PME 0.12, ALE-ALE 0.06. Carapace without any pattern. Abdomen dorsum pale white. Legs: 0.85 long. Leg spination: femur I v1-2-2; II v0-2-2; III-IV d1-0-1; tibia I v2-2-2-2-2, II v2-2-2-2-2, III 



Figs. 246-256. Predatoroonops rickhawkins, n. sp., female. 246-247, Body: 246, dorsal view; 247, ventral view. 248, Abdomen, ventral view. 249-251, Carapace: 249, frontal view. 250, lateral view. 251, ventral view. 252-253, Leg I: 252, prolateral view; 253, retrolateral view. 254, Pedipalp, prolateral view. 255-256, Internal genitalia: 255, ventral view; 256, dorsal view.

d0-1-0; p0-1-0; v0-1-1; r0-1-1, IV d0-1-0; v01-1; r1-1-0; metatarsus I v2-2-2-2, II v2-2-2-2, III v0-1-2; IV d0-0-1; p0-1-1; v0-1-2; r0-1-1. Internal genitalia with elongated anterior receptaculum with truncated tip and small cordiform posterior receptaculum; large and stout apodema plate with enlarged and curved apodema process (figs. 182-183, 256).

Other MATERIAl EXAMINED: BRAZIL: Minas Gerais: Alto Caparaó, Parque Nacional do Caparaó, $41^{\circ} 9^{\prime} \mathrm{W}, 20^{\circ} 5^{\prime} \mathrm{S}$, May 01-07, 2002, pitfall (Equipe Biota, IBSP 135863, PBI_OON 11130), 1 ; ; (IBSP 135865, PBI_OON 11841), 1 శ ; (IBSP 135869, PBI_OON 11131), 1 के; (IBSP 135870, PBI_OON 11843), 1우일 (IBSP 135867, PBI_OON 11844), 1 우.

DisTRIBUTION: Known only from the state of Minas Gerais, Brazil (map 3).
Predatoroonops dutch Brescovit, Rheims, and Bonaldo, new species

Figures 21, 257-277, 303-308; map 2

TyPes: Male holotype and female paratype from Ipiaú $\left(14^{\circ} 7^{\prime} 60^{\prime \prime} \mathrm{S}, 39^{\circ} 43^{\prime} 60^{\prime \prime} \mathrm{W}\right)$, Bahia, Brazil (Jan. 2007, C. Máximo) deposited in IBSP 123703 (PBI_OON 11021) and IBSP 160849 (PBI_OON 11020) respectively.

ETYMOLOGY: The specific name refers to the main character in the movie "Predator," Major Alan "Dutch" Schaefer, played by Arnold Schwarzenegger.

Diagnosis: Males of Predatoroonops dutch differ from those of the remaining species by the very long, subdistal, narrow furrow, subdistal apophysis absent (fig. 21). Females can be easily distinguished from those of the 

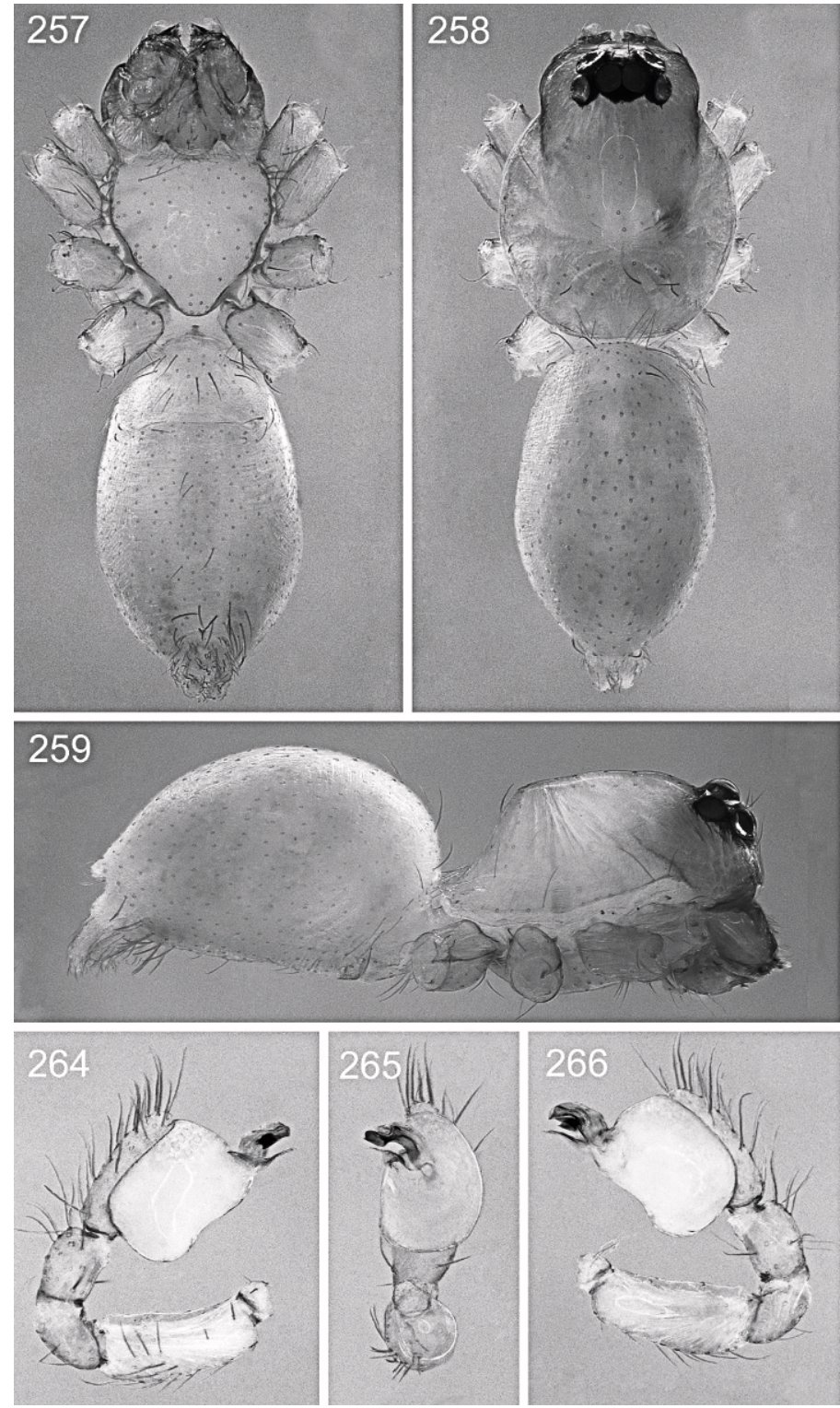
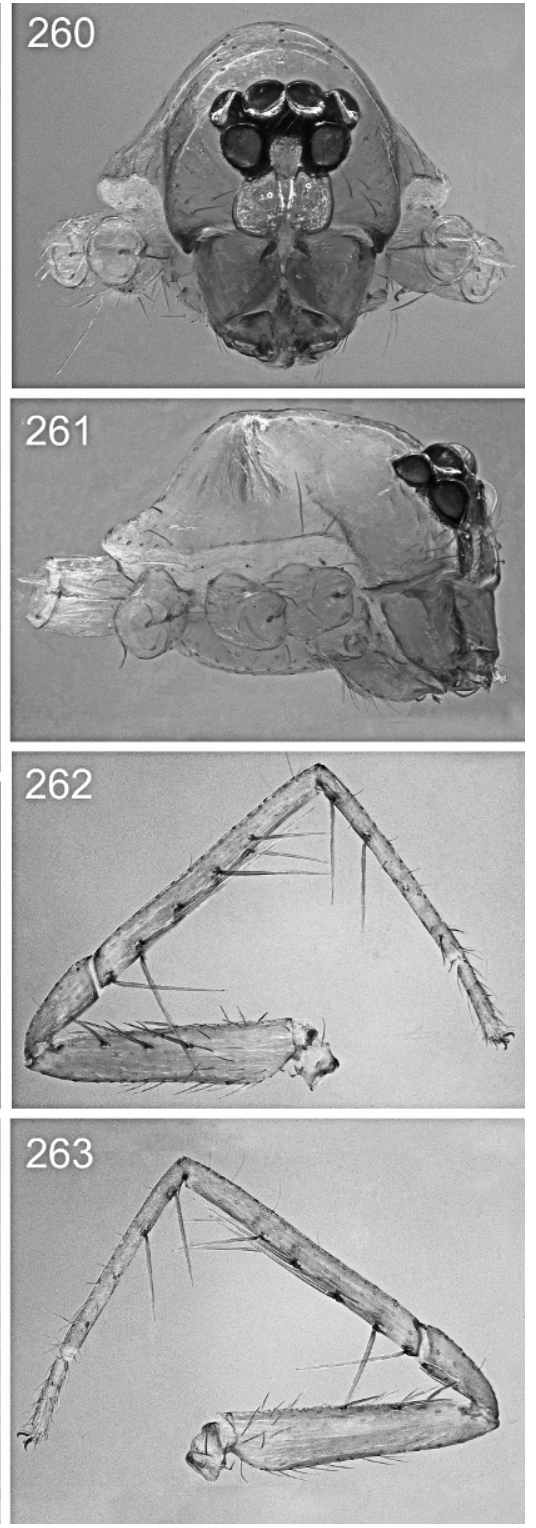

Figs. 257-266. Predatoroonops dutch, n. sp., male. 257-259, Body: 257, ventral view; 258, dorsal view; 259, lateral view. 260-261, Carapace: 260, frontal view; 261, lateral view. 262-263, Leg I: 262, prolateral view; 263, retrolateral view. 264-266, Palp: 264, prolateral view; 265, ventral view; 266, retrolateral view.

remaining species by the larger, flattened, long apodema plate with apex close to the distal area of anterior receptaculum (fig. 276).

MALE (PBI_OON 11021): Total length 1.80. Carapace 0.75 long, 0.65 wide. ALE 0.10, PLE 0.10, PME 0.12, ALE-ALE 0.06. Carapace orange-brown, without any pattern, anterolateral corners with slightly scler- otized triangular projections (figs. 259, 261). Sternum yellow. Chelicerae, endites, and labium orange-brown. Clypeus with very small needlelike setae (fig. 21). Chelicerae anterior face with very small triangular median furrow, elongated subdistal narrow furrow, subdistal apophysis absent, short and bifid upwardcurving distal apophysis and subtriangular 

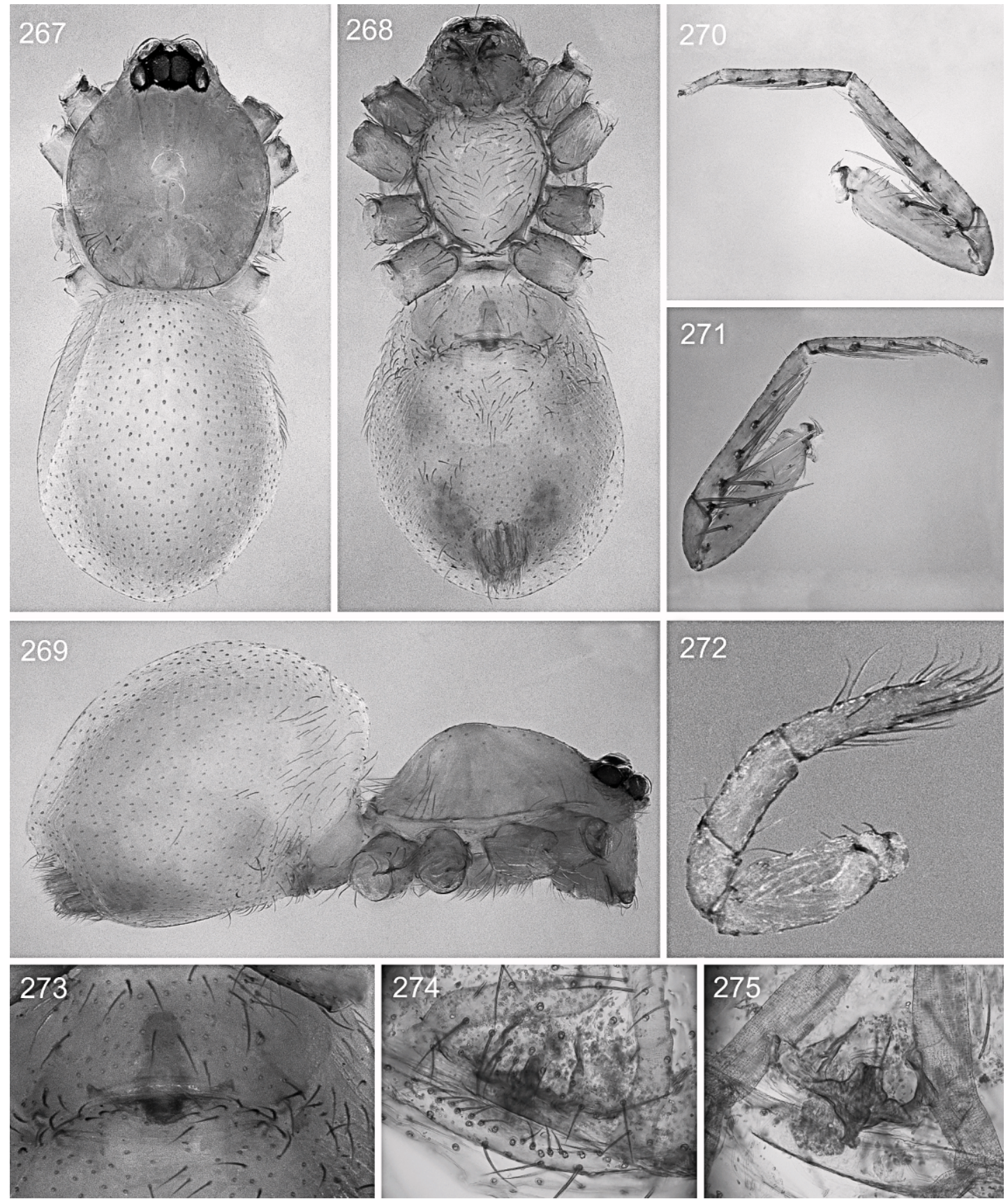

Figs. 267-275. Predatoroonops dutch, n. sp., female. 267-269, Body: 267, dorsal view; 268, ventral view; 269, lateral view. 270-271, Leg I: 270, prolateral view; 271, retrolateral view. 272, Pedipalp, retrolateral view. 273-275, Internal genitalia: 273, ventral view; 274, ventral view, cleared; 275, dorsal view. 

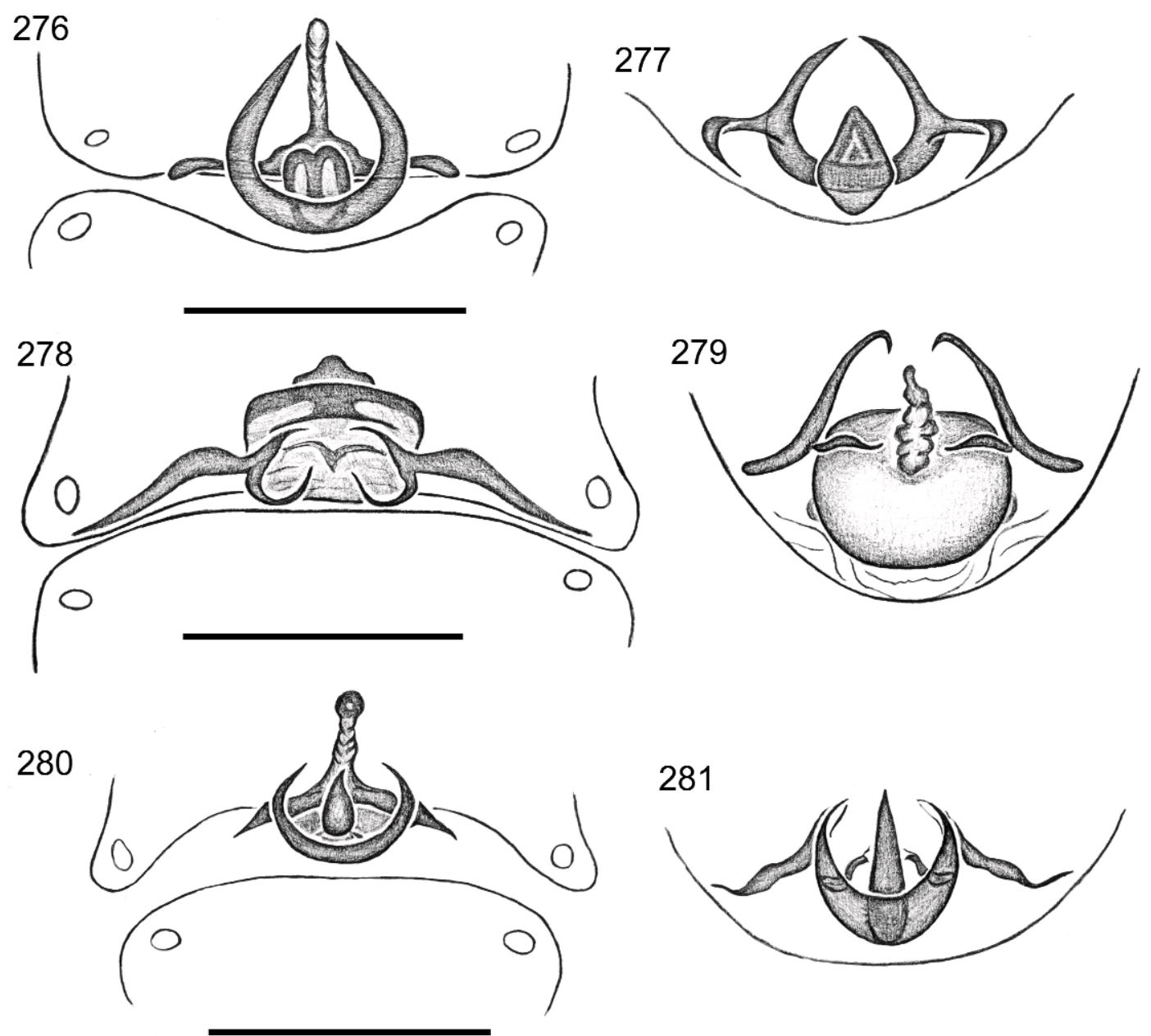

281
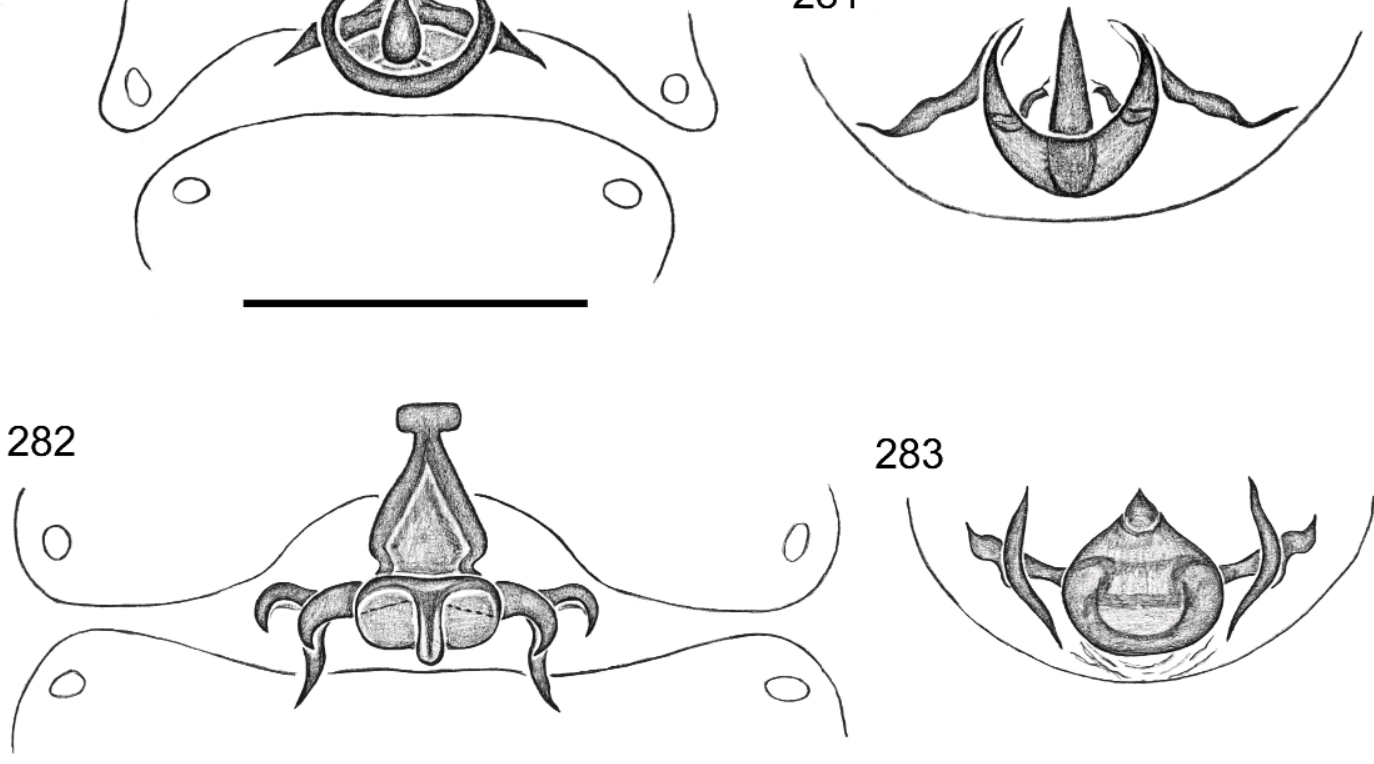

283

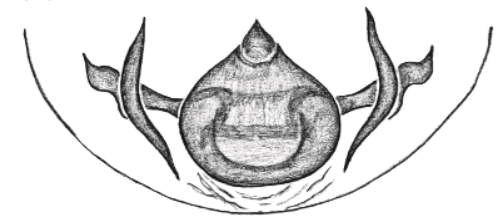

Figs. 276-283. Predatoroonops species, female internal genitalia. 276-277, Predatoroonops dutch, n. sp.: 276, dorsal view; 277, posterior view. 278-279, P. dillon, n. sp.: 278, dorsal view; 279, posterior view. 280281, $P$. vallarta, n. sp.: 280, dorsal view; 281, posterior view. 282-283, $P$. yautja, n. sp.: 282, dorsal view; 283, posterior view. 

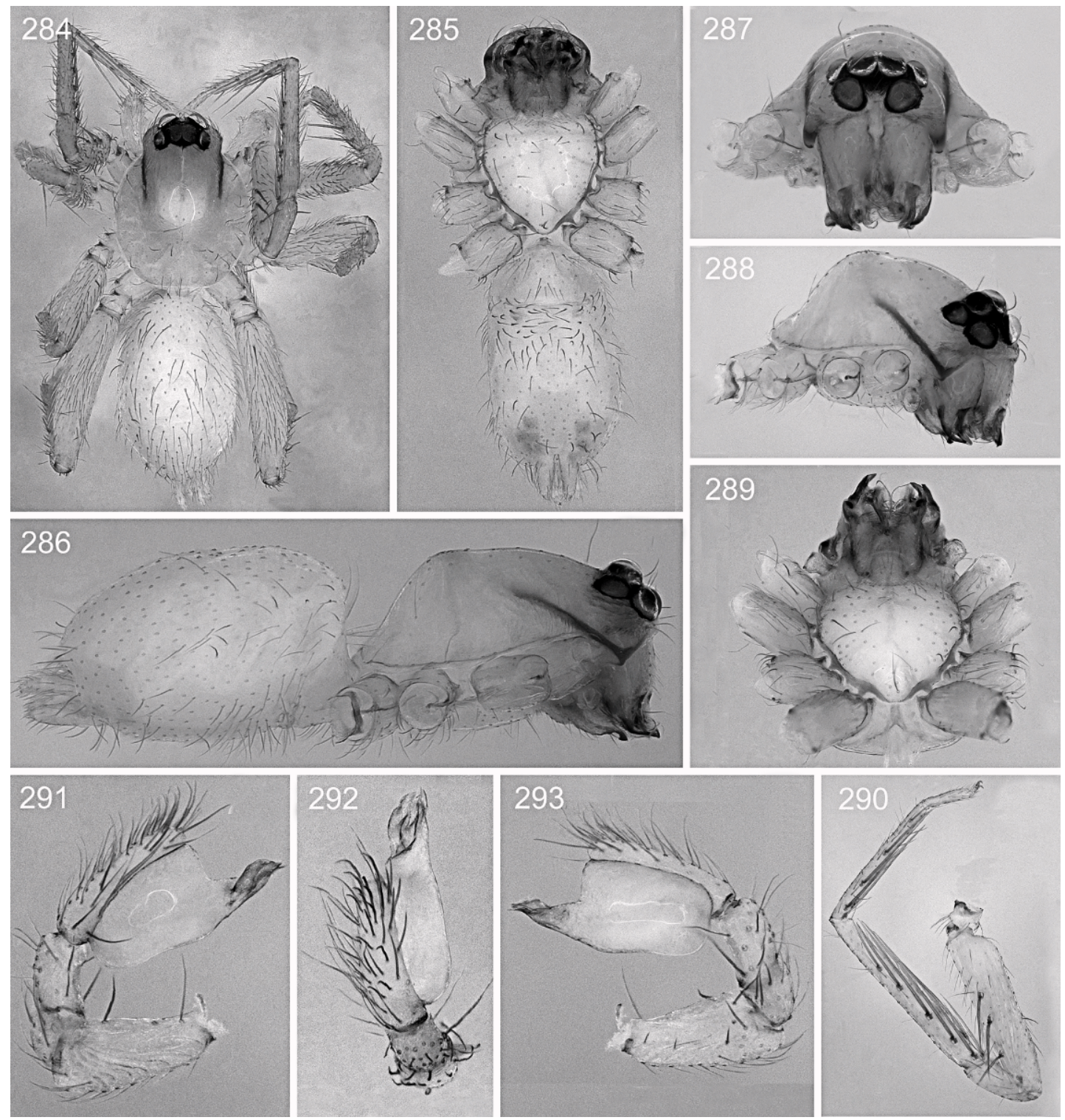

Figs. 284-293. Predatoroonops dillon, n. sp., male. 284-286, Body: 284, dorsal view; 285, ventral view; 286, lateral view. 287-289, Carapace: 287, frontal view. 288, lateroventral view. 289, ventral view. 290, Leg I, prolateral view. 291-293, Palp: 291, retrolateral view; 292, dorsolateral view; 293, prolateral view.

condilar projection present (fig. 21). Abdomen dorsum pale orange. Legs orange-brown, femur I 0.75 long. Leg spination: femora I-II d1-0-0; v2-22; III-IV d1-0-0; I v2-2-2-2-2, II v2-2-2-2-2, III d01-0; p0-1-1; v0-2-2; r0-1-1; IV d0-1-0; p1-1-0; v0-12; r1-1-0; metatarsus I v2-2-2-2, II v2-2-2-2, III v02-2; r0-1-1; IV p0-1-1; v0-1-1; r0-1-1. Male palp proximal segments brown, cymbium yellow, bulb white, truncated dorsally and slender hyaline process short with very large base (figs. 264 266).

Female (PBI_OON 10984): Total length 2.10. Carapace 0.70 long, 0.65 wide. ALE 0.10, PLE 0.10, PME 0.12, ALE.ALE 0.07. Abdomen dorsum orange. Legs orange, femur I 0.70. Leg spination: femur: I v2-1-2; II v1-2-1; III d1-0-0; IV d1-0-1, tibia I v2-22-2-2, II v2-2-2-2-2, III-IV d0-1-0; p0-1-1; 

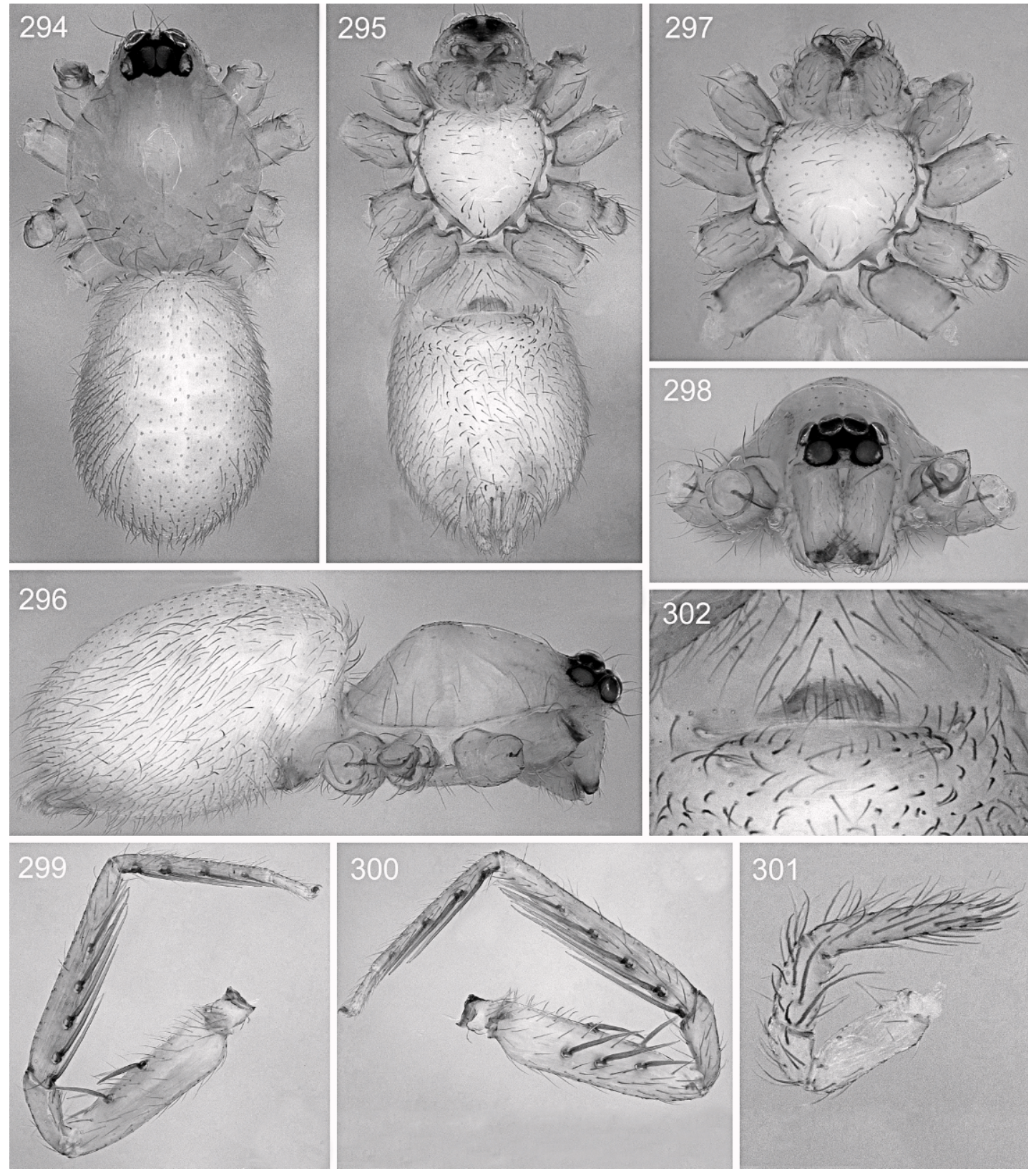

Figs. 294-302. Predatoroonops dillon, n. sp., female. 294-296, Body: 294, dorsal view; 295, ventral view; 296, lateral view. 297-298, Carapace: 297, ventral view. 298, frontal view. 299-300, Leg I: 299, prolateral view. 300, retrolateral view. 301, Pedipalp, prolateral view. 302, Internal genitalia, ventral view.

v0-1-2; r0-1-1; metatarsus I v2-2-2-2, II v2-22-2, III v0-0-1; r0-1-1; IV d1-0-1; p0-1-1; v01-2; r0-1-1. Internal genitalia with slender, elongated anterior receptaculum folded at tip and cordiform posterior receptaculum; semi- circular and flattened apodema plate with long and curved apodema process (figs. 273277).

OTher MATERIAl ExAMINED: BRAZIL: Bahia: Ipiaú, $14^{\circ} 7^{\prime} 60^{\prime \prime} \mathrm{S}, 39^{\circ} 43^{\prime} 60^{\prime \prime} \mathrm{W}$, Jan. 2007 

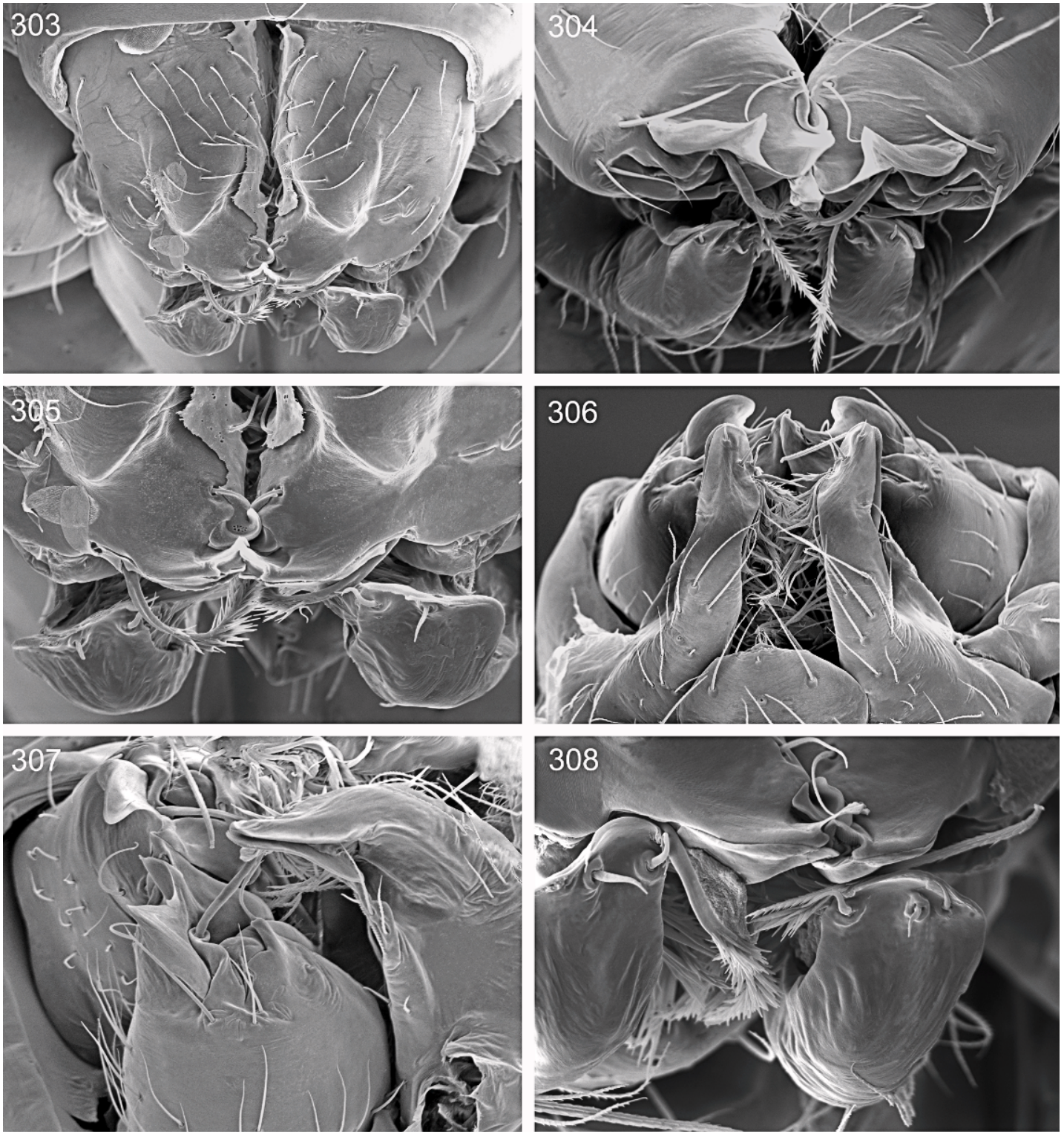

Figs. 303-308. Predatoroonops dutch, n. sp., male chelicerae, distal area. 303, Frontal view. 304-305, Detail of distal and subdistal apophysis, frontal view. 306, Endites, ventral view. 307, Chelicerae and endites, lateral view. 308, Detail of distal and subdistal process, and apex of endite, frontal view.

(IBSP 118632-118635, PBI OON 11199; 11069-11071), 3ㅊ 1웅 (IBSP 160850-160852, PBI OON 11089-11090, 11200), 3우 (IBSP 123703-123706, PBI_OON 10983-10984, 11020-11021) all collected by C. Máximo.

Distribution. Known only from the state of Bahia, Brazil (map 2).
Predatoroonops dillon Brescovit, Rheims, and Bonaldo, new species

Figures 22, 278-279, 284-302; map 2

TyPes: Male holotype and female paratype from Estação Ecológica de Murici, $09^{\circ} 15^{\prime} \mathrm{S}, 35^{\circ} 51^{\prime \prime} \mathrm{W}$, pitfall, Murici, Alagoas, 

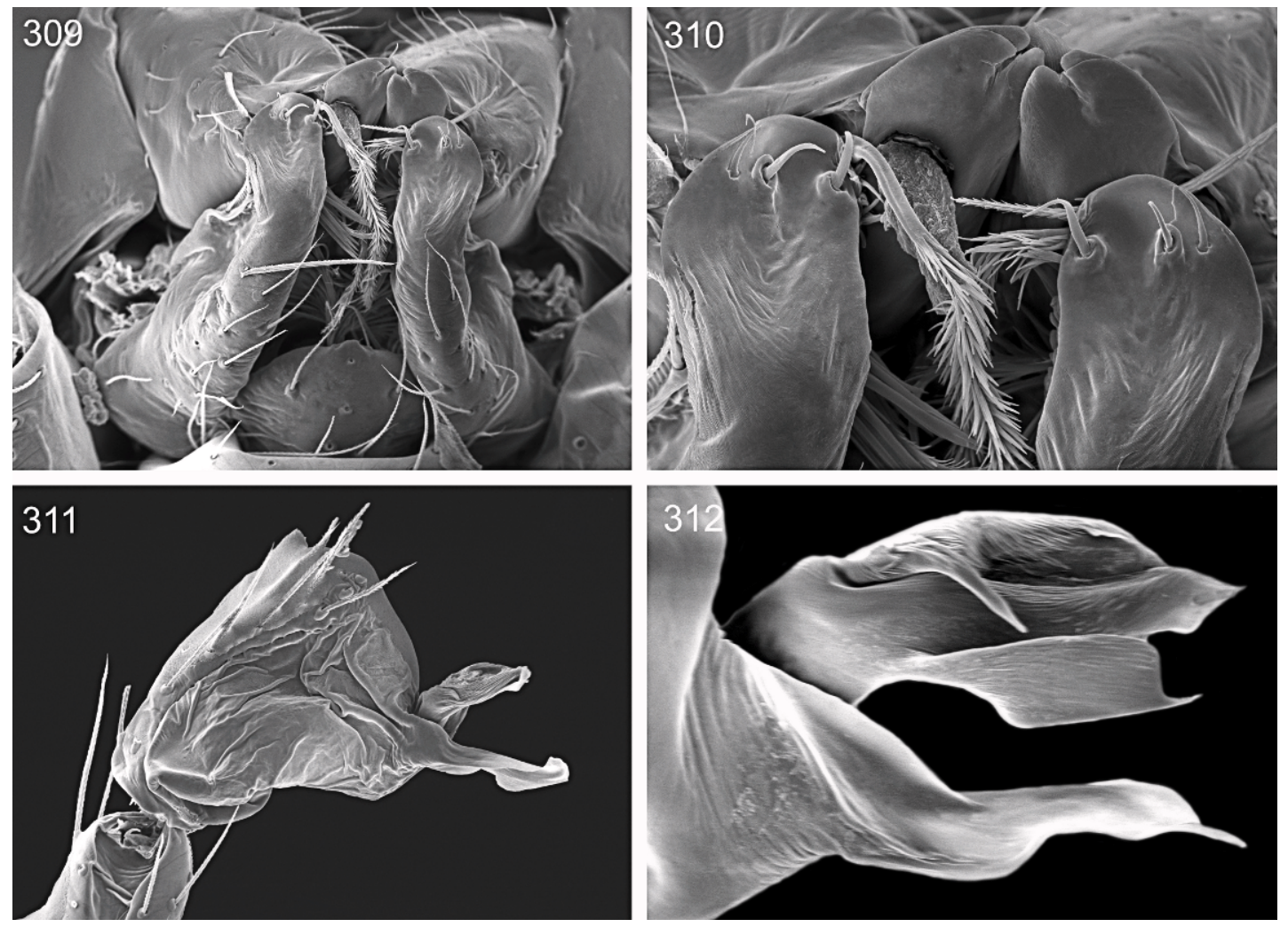

Figs. 309-312. Predatoroonops vallarta, n. sp., male. 309-310, Endites and labium: 309, ventral view; 310, detail of distal area of endites and distal apophysis of chelicerae, ventral view. 311-312, Palp: 311, prolateral view; 312, detail of distal and subdistal process, prolateral view.

Brazil (Sept. 13-20, 2003; Equipe Biota) deposited in IBSP 68121 (PBI_OON 10991) and (IBSP 68120 (PBI_10993), respectively.

ETYMOLOGY: The specific name refers to the character George Dillon, a former teammate of Dutch and current CIA agent, played by Carl Weathers in the movie "Predator."

Diagnosis: Males of Predatoroonops dillon differ from those of the remaining species by the very long subdistal apophysis, concave at tip, with large base and by the conical, short and curved distal apophysis (fig. 22). Females can be easily distinguished from those of the remaining species by the short anterior receptaculum, squared and massive posterior receptaculum and very long apodema plate (figs. 278-279).

MALE (PBI_OON 10991): Total length 2.00. Carapace 1.0 long, 0.6 wide. ALE 0.12, PLE 0.10, PME 0.14, ALE-ALE 0.06.
Carapace orange, without any pattern, anterolateral corners with sclerotized triangular projections (figs. 286-288). Sternum yellow. Chelicerae, endites, and labium pale orange. Clypeus with very small needlelike setae (fig. 22). Chelicerae anterior face with median furrow short, subdistal furrow inconspicuous with median group of 3-4 setae, subdistal apophysis very long, concave at tip and with large base; distal apophysis short; conical and condylar projection absent (fig. 22). Abdomen dorsum pale orange. Legs yellow, femur I 0.9 long. Leg spination: femora: I-II v2-2-1, III-IV d1-0-1; tibia I v2-2-2-2-2, II v2-2-2-2-2, III d0-1-0; p0-0-1; v0-1-1; r0-0-1; IV d0-1-0; p0-1-1; v0-1-1; r0-11 ; metatarsus I v2-2-2-2, II v2-2-2-2, III d0-01 ; v0-1-1; r0-0-1; IV d1-0-1; p0-1-1; v0-1-2; r0-1-1. Male palp proximal segments white; cymbium yellow, bulb white, with elongated distal area, slender hyaline process very large 



Figs. 313-320. Predatoroonops vallarta, n. sp., male. 313-315, Carapace: 313, dorsal view; 314, frontal view; 315, laterofrontal view. 316-317, Leg I: 316, prolateral view; 317, retrolateral view. 318-320, Palp: 318, retrolateral view; 319, ventral view; 320, prolateral view.

and short laminar hyaline process (figs. 291293).

Female (PBI_OON 10993): Total length 2.10. Carapace 1.0 long, 0.70 wide. ALE 0.12, PLE 0.12, PME 0.14, ALE-ALE 0.06.
Female palp prolateral tibia with a prolateral, longitudinally oblique row of 3-4 very long setae (fig. 301). Abdomen dorsum orange. Legs: femur I 0.9 long. Leg spination: femora I-II v2-2-1; III d1-0-0; v0-0-1; IV 


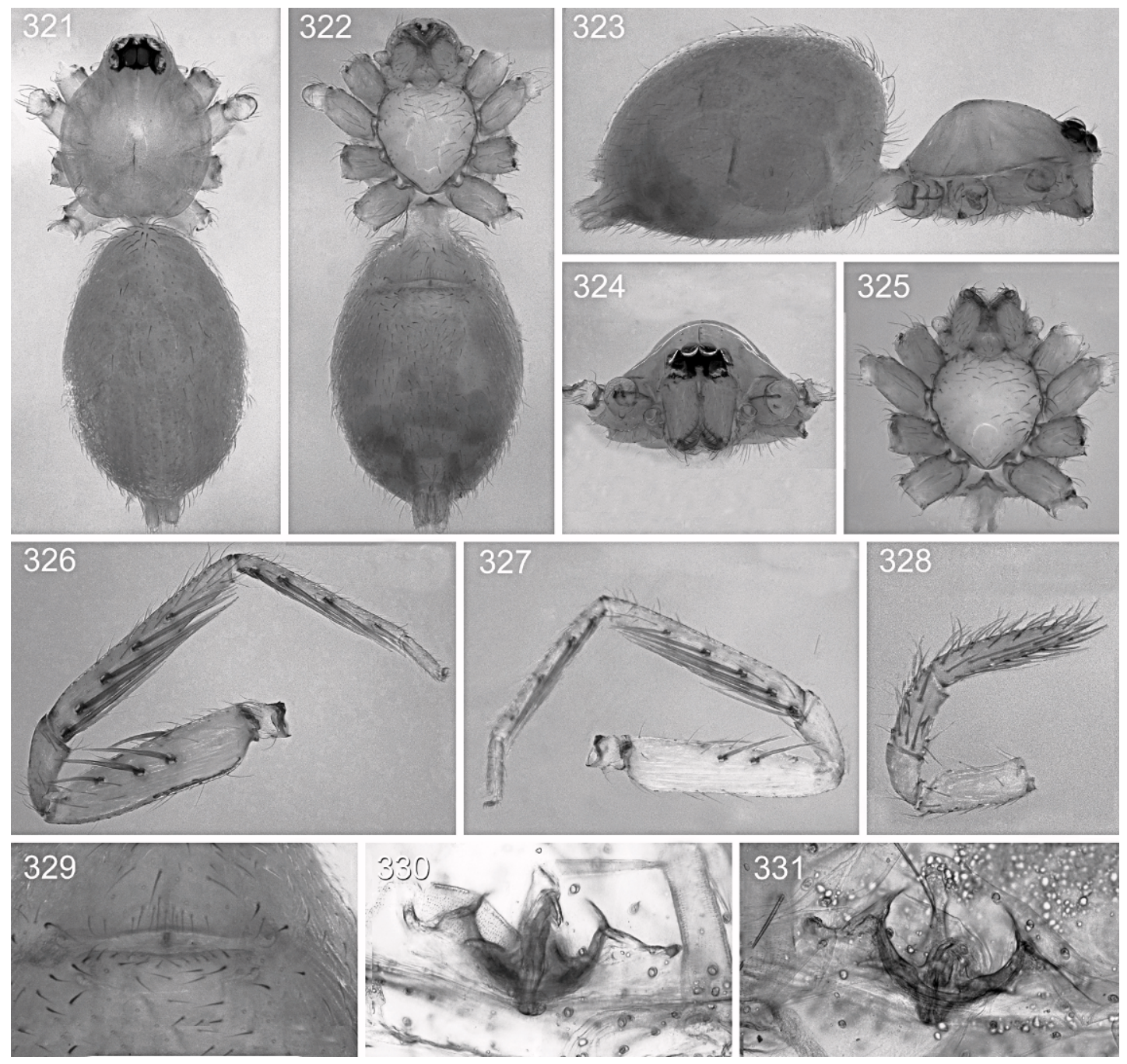

Figs. 321-331. Predatoroonops vallarta, n. sp., female. 321-323, Body: 321, dorsal view; 322, ventral view; 323, lateral view. 324-325, Carapace: 324, frontal view; 325, ventral view. 326-327, Leg I: 326, prolateral view; 327, retrolateral view. 328, Pedipalp, prolateral view. 329-331, Internal genitalia: 329, ventral view; 330, dorsal view, cleared; 331, dorsal view, clarified.

d1-0-1; v0-0-1; tibia I v2-2-2-2-2, II v2-2-2-22, III d0-1-0; p0-0-1; v0-1-2; r0-0-1; IV d0-1-0; p1-0-0; v0-1-2; r1-0-1; metatarsus I v2-2-2-2, II v2-2-2-2, III d0-0-1; v0-1-2; r0-1-1; IV d0-01 ; $\mathrm{p} 0-1-1 ; \mathrm{v} 0-1-2 ; \mathrm{r} 0-1-1$. Internal genitalia with short, folded anterior receptaculum and squared, solid posterior receptaculum that appears globose in posterior view; apodema plate very long, flattened at basis with slender and curved apodema process (figs. 278-279).

Other MAterial ExAmined: BRAZIL: Alagoas: Murici, Estação Ecológica de Mur- ici, $09^{\circ} 15^{\prime} \mathrm{S}, 35^{\circ} 51^{\prime \prime} \mathrm{W}$, Sept. 13-20, 2003, pitfall (Equipe Biota, IBSP 68119, PBI_OON 10992), $1 \hat{\delta}$.

Distribution: Known only from the type locality, in the state of Alagoas, Brazil. This is the northernmost record of the genus (map 2).

Predatoroonops vallarta Brescovit, Rheims, and Bonaldo, new species

Figures 23, 280-281, 309-331; map 4

TYPES: Male holotype and female paratype from Restinga da Marambaia $\left(23^{\circ} 02^{\prime} \mathrm{S}-23^{\circ} 06^{\prime} \mathrm{S}\right.$, $\left.43^{\circ} 45^{\prime} \mathrm{W}-43^{\circ} 54^{\prime} \mathrm{W}\right)$, Rio de Janeiro, Rio de 

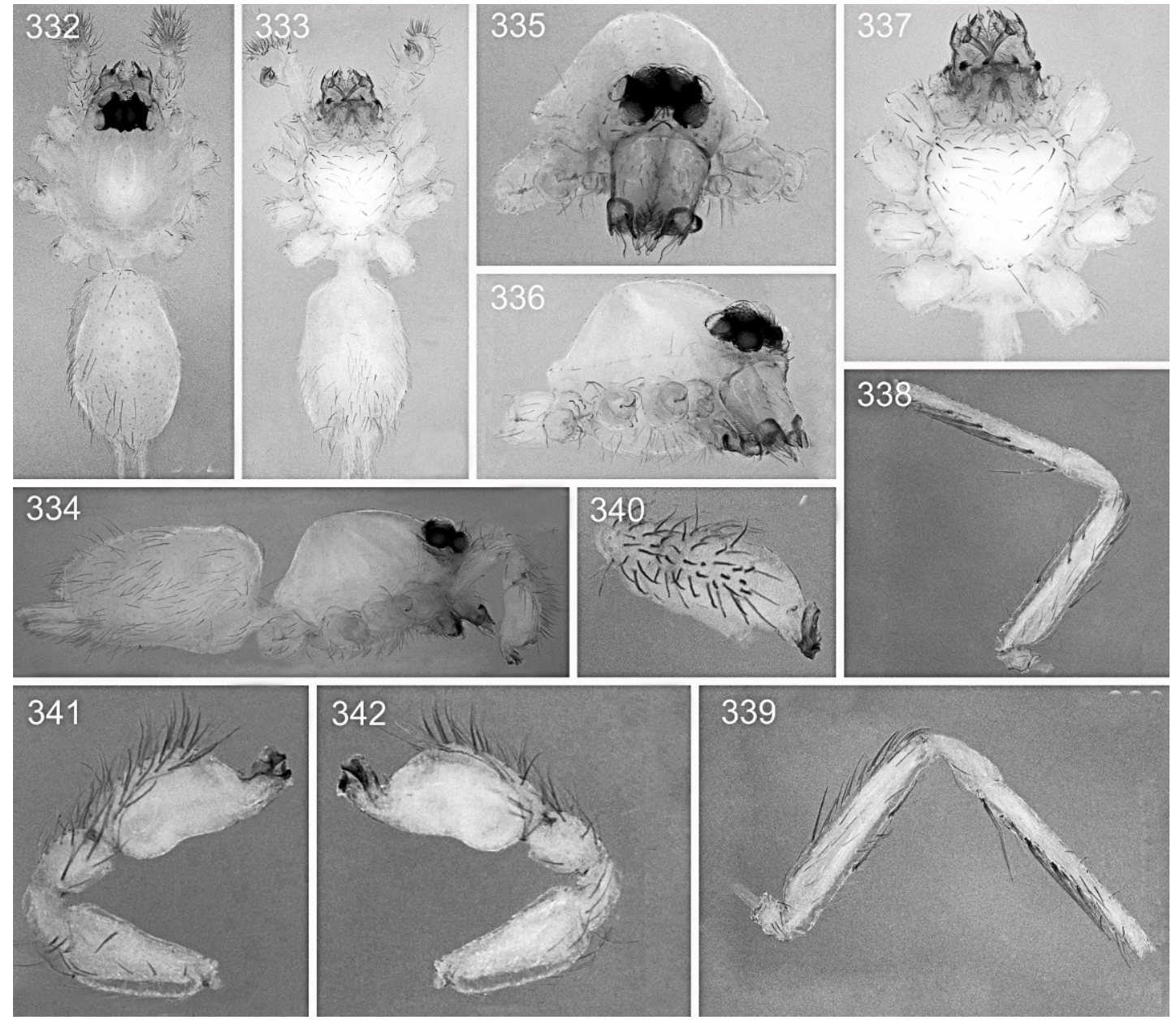

Figs. 332-342. Predatoroonops phillips, n. sp., male. 332-334, Body: 332, dorsal view; 333, ventral view; 334, lateral view. 335-337, Carapace: 335, frontal view; 336, laterofrontal view; 337, ventral view. 338-339, Leg I: 338, prolateral view; 339, retrolateral view. 340-342, Palp: 340, dorsal view; 341, prolateral view; 342, retrolateral view.

Janeiro, Brazil, pitfall (2005-2007, E.F. Ramos), deposited in IBSP 90504 (PBI_OON 10923) and IBSP 90505 (PBI_OON 10924), respectively.

ETYMOLOGY: The specific name refers to Puerto Vallarta, Mexico, one of the filming locations for the movie "Predator"; the set there is now a tourist attraction.

Diagnosis: Males of Predatoroonops vallarta differ from those of the remaining species by the elongated subdistal furrow, the subdistal apophysis with a large base and a long and slender tip (fig. 23). Females can be easily distinguished from those of the remaining species by the small, drop-shaped posterior receptaculum and semicircular, flattened apodema plate (figs. 280-281, 330-331).

MALE (PBI_OON00010923): Total length 1.90. Carapace 0.80 long, 0.65 wide. ALE 0.10, PLE 0.10, PME 0.12, ALE-ALE 0.06. Carapace pale orange, without any pattern, anterolateral corners with slightly sclerotized triangular projections (fig. 315). Sternum yellow. Chelicerae, endites, and labium pale orange. Clypeus with very small needlelike setae smooth (fig. 23). Chelicerae anterior face without median furrow, subdistal furrow short, long subdistal apophysis with large base, distal apophysis short, condylar 

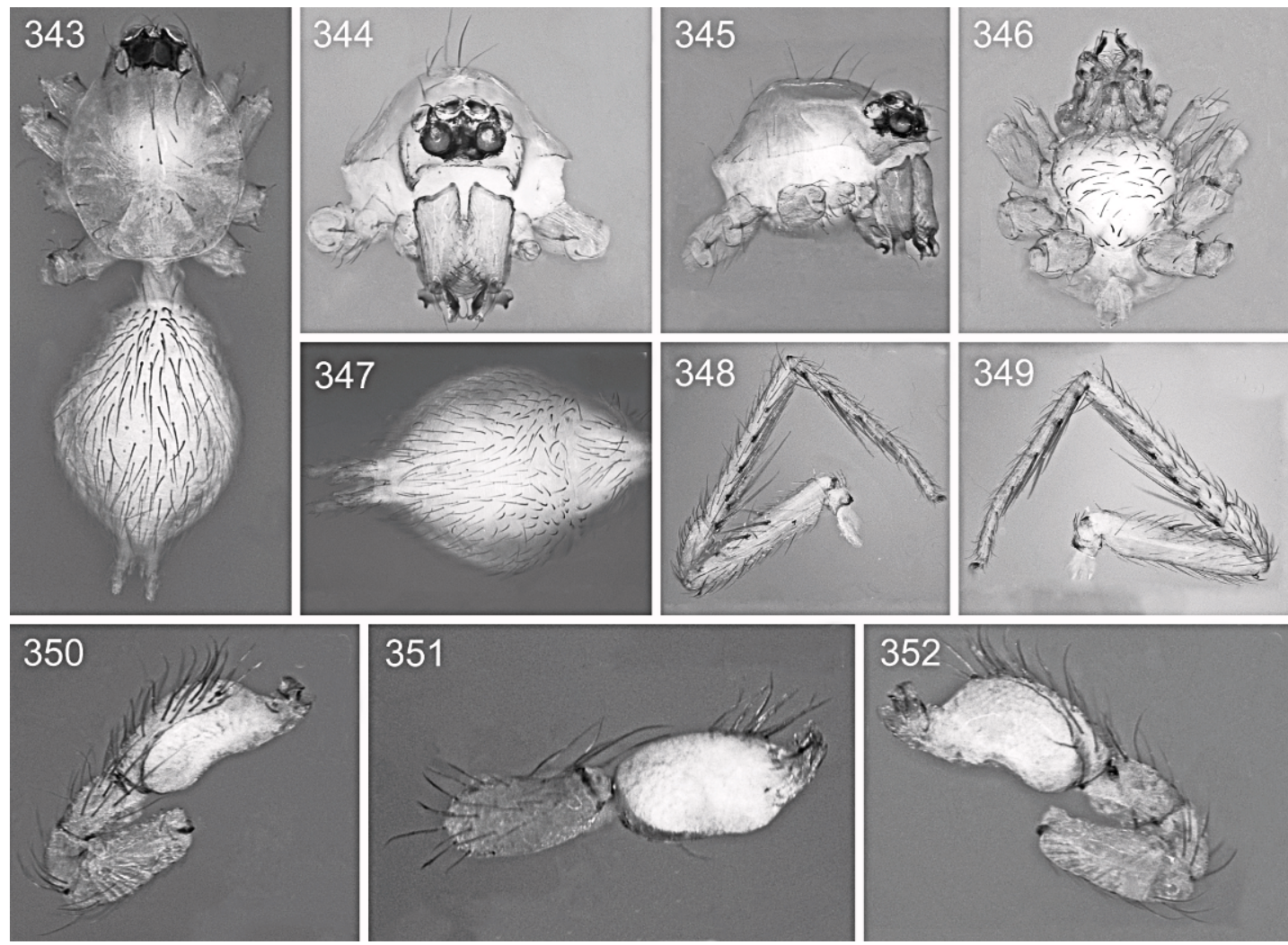

Figs. 343-352. Predatoroonops yautja, n. sp., male. 343, Body, dorsal view. 344-346, Carapace: 344, frontal view; 345, lateral view; 346, ventral view. 347, Abdomen, ventral view. 348-349, Leg I: 348, prolateral view; 349, retrolateral view. 350-352, Palp: 350, prolateral view; 351, ventral view; 352, retrolateral view.

projection absent (fig. 23). Abdomen dorsum white. Legs pale orange, femur I 0.65. Leg spination: femur I p0-0-3; r0-1-1, II d1-0-0; p0-0-2; r0-1-1, III d0-1-0, IV d1-0-1, tibia I v 2-2-2-2-2, II v 2-2-2-2-2, III p1-1-0; IV p1-1-0; r1-1-0; metatarsi I-II p0-0-1; v2-2-2, III r0-01, IV p1-1-0; r1-1-0. Male palp proximal segments yellow; cymbium yellow, bulb white, truncated dorsally, with narrow hyaline process (figs. 318-320).

FEMALE (PBI_OON00010924): Total length 2.20. Carapace 0.80 long, 0.65 wide. ALE 0.08, PLE 0.08, PME 0.10, ALE-ALE 0.06. Abdomen dorsum orange. Legs orange, femur I 0.70. Leg spination: femur I p0-0-3; r0-1-1; II p0-0-2; v0-1-0; IV d0-1-1; tibia I v 2-2-2-2-2, II v 2-2-2-2, III d0-1-0; IV d0-1-0; v0-1-1; r1-0-0, metatarsus I p0-0-1; v2-2-2; II $\mathrm{v} 2-2-2 ;$ IV $\mathrm{d} 0-0-1 ; \mathrm{p} 0-0-1 ; \mathrm{v} 0-0-1$. Internal genitalia with elongated, receptaculum folded anteriorly with globose tip; posterior receptaculum small, drop shaped; apodema plate semicircular, flattened, and with long and sinuous apodema process (figs. 280-281, 330-331).

Other MATERIAl EXAMINED: BRAZIL: Rio de Janeiro: Rio de Janeiro, Parque Nacional da Tijuca, $22^{\circ} 55^{\prime} \mathrm{S}-23^{\circ} 00^{\prime} \mathrm{S}, 43^{\circ} 11^{\prime} \mathrm{W}-43^{\circ} 19^{\prime} \mathrm{W}$, Jun. 16, 1994 (M. Ramirez and R. Baptista, IBSP 160844, PBI_OON 11198), 1 के 1; Restinga da Marambaia, $23^{\circ} 02^{\prime} \mathrm{S}-23^{\circ} 06^{\prime} \mathrm{S}, 43^{\circ} 45^{\prime} \mathrm{W}-$ $43^{\circ} 54^{\prime} \mathrm{W}$, pitfall, 2005-2007 (E.F. Ramos, IBSP 118628-118631, PBI_OON 11066-11068, 11197), $2 \hat{\delta} \quad 2 \%$; (IBSP 160845-160847, PBI_OON 10981-10982, 11193-11196), 3 3ิ 3 우 (MACN, PBI_OON 10982; 10923), 1 के 1 우.

DisTRIBUTION: Known only from the state of Rio de Janeiro, Brazil (map 4). 



Figs. 353-361. Predatoroonops yautja, n. sp., female. 353, Abdomen, ventral view. 354-356, Carapace: 354, dorsal view; 355, ventral view; 356, lateral view. 357-358, Leg I: 357, prolateral view; 358, retrolateral view. 359-360, Pedipalp: 359, prolateral view; 360, retrolateral view. 361, Internal genitalia, ventral view.

\section{The peterharlli Group}

Species belonging to this group do not have the median and subdistal furrows in the chelicerae, which has only simple distal projections (figs. 24-29). The groove in the lateral anterior border of carapace is attenuated (figs. 372, 418) or absent (figs. 336-345). The group includes six species: phillips, yautja, peterhalli, mctiernani, chicano, and olddemon.
Predatoroonops phillips Brescovit, Rheims, and Santos, new species

Figures 24, 332-342; map 3

Types: Male holotype from Reserva Biológica de Una, $15^{\circ} 07^{\prime}-15^{\circ} 15^{\prime} \mathrm{S}, \quad 39^{\circ} 15^{\prime}-$ $39^{\circ} 25^{\prime} \mathrm{W}$, Una, Bahia, Brazil, pitfall (Nov. 15-28, 2000, A.D. Brescovit) deposited in IBSP 46113 (PBI_OON 10994). 

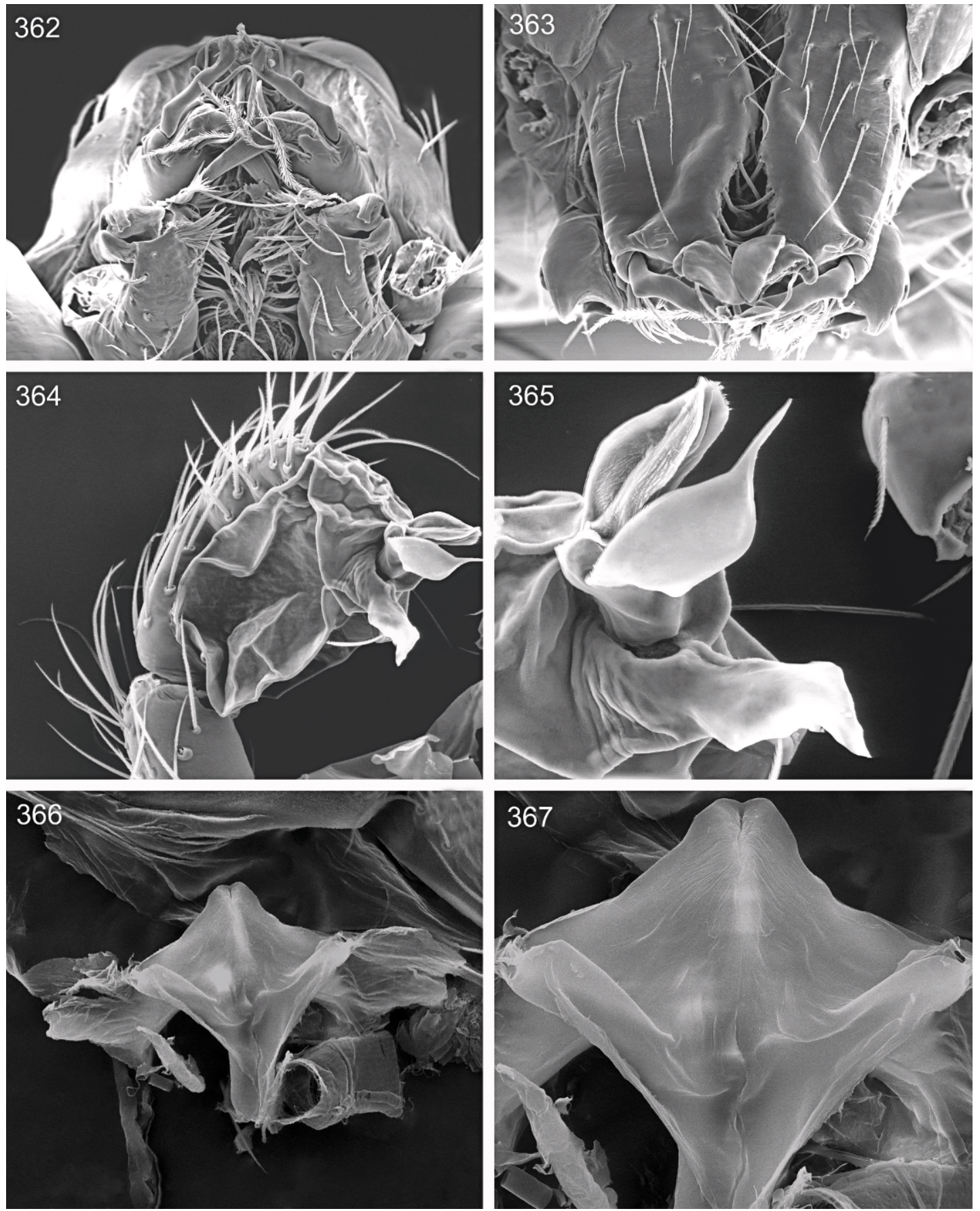

Figs. 362-367. Predatoroonops peterharlli, n. sp. 362-365, Male. 362, Chelicerae and endites, distal area, ventral view. 363, Chelicerae, frontal view. 364-365, Palp: 364, frontal view; 365, detail of distal and subdistal apophysis. 366-367, Female, internal genitalia: 366, dorsal view; 367, detail of anterior and posterior receptaculum, dorsal view. 

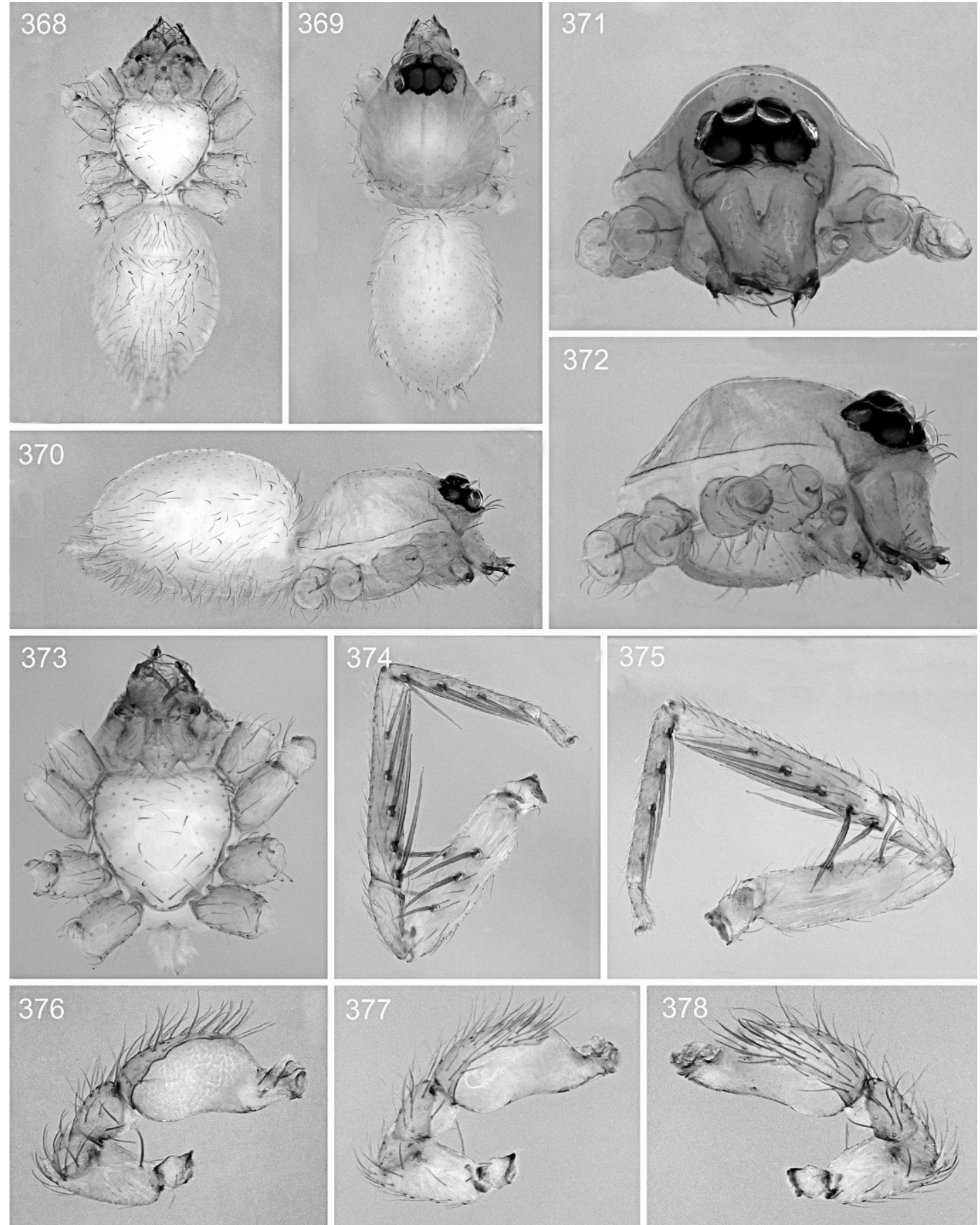

Figs. 368-378. Predatoroonops peterharlli, n. sp., male. 368-370, Body: 368, ventral view; 369, dorsal view; 370, lateral view. 371-373, Carapace: 371, frontal view; 372, lateral view; 373, ventral view. 374-375, Leg I: 374, prolateral view; 375, retrolateral view. 376-378, Palp: 376, retrolatero-frontal view; 377, retrolateral view; 378, prolateral view. 

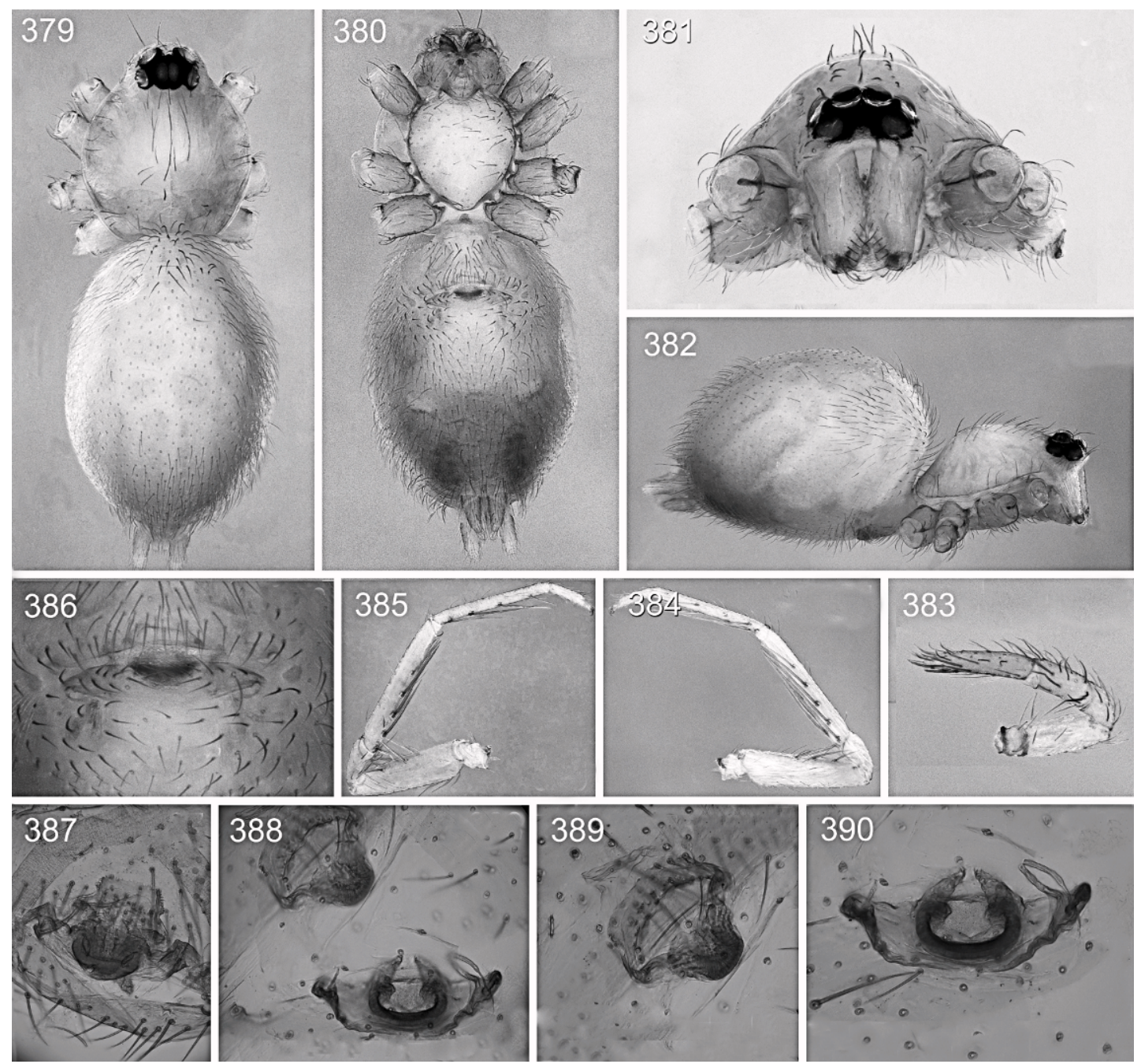

Figs. 379-390. Predatoroonops peterharlli, n. sp., female. 379-380, Body: 379, dorsal view; 380, ventral view. 381, Carapace, frontal view. 382, Body, lateral view. 383, Pedipalp, prolateral view. 384-385, Leg I: 384, prolateral view; 385, retrolateral view. 386-390, Internal genitalia: 386, ventral view; 387, dorsal view, with separated receptacula; 388, anterior receptaculum, clarified; 390, posterior receptaculum, clarified.

ETYMOLOGY: The specific name refers to the character General Homer Phillips, played by Robert G. Armstrong in the movie "Predator"; General Phillips is the coordinator of the mission, who assigns Dutch's team based upon its reputation.

Diagnosis: Males of Predatoroonops phillips differ from those of the remaining species by the long, slender and sinuous subdistal apophysis and flattened distal apophysis with very slender tip on chelicerae (fig. 24).
Male (PBI_OON 10944): Total length 1.35. Carapace 0.75 long, 0.55 wide. ALE 0.06, PLE 0.08, PME 0.08, ALE-ALE 0.06. Carapace white, with brown stripe along margin of pars cephalica, anterolateral corners without sclerotized projections (figs. 335336). Sternum, chelicerae, endites, and labium yellowish white. Clypeus with very small needlelike setae (fig. 24). Chelicerae anterior face without median and subdistal furrow, subdistal apophysis long and slender, distal 
391

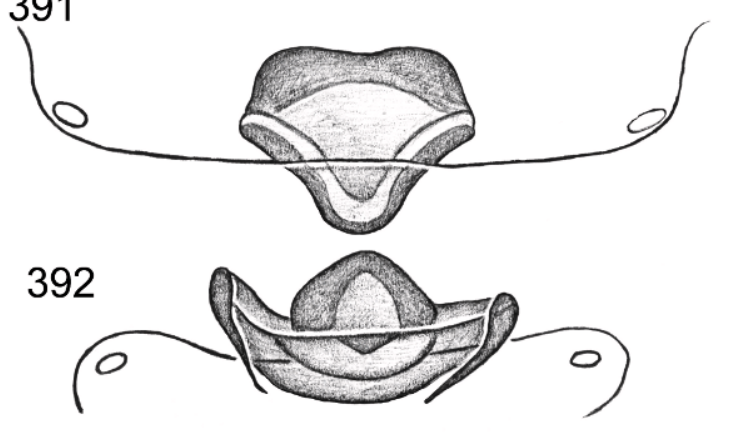

393

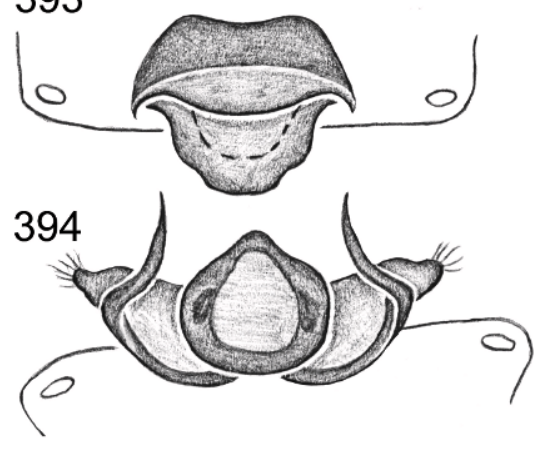

397

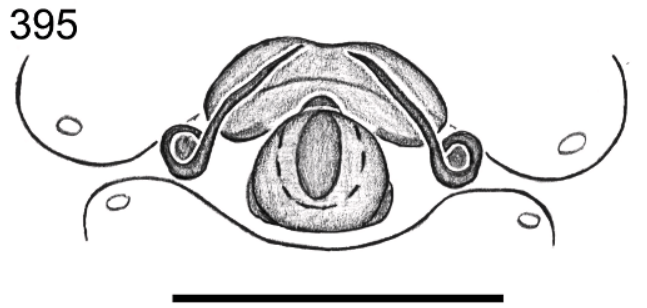

396

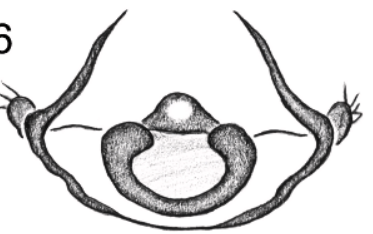

399

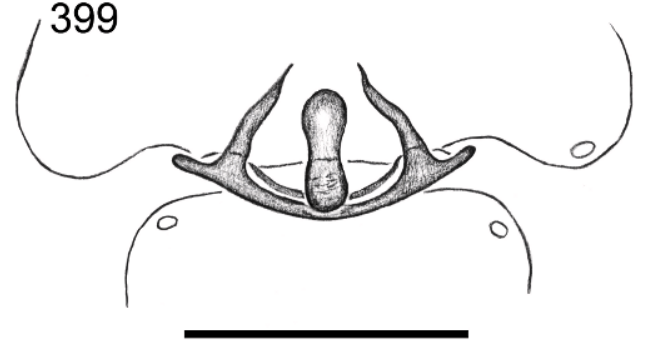

401
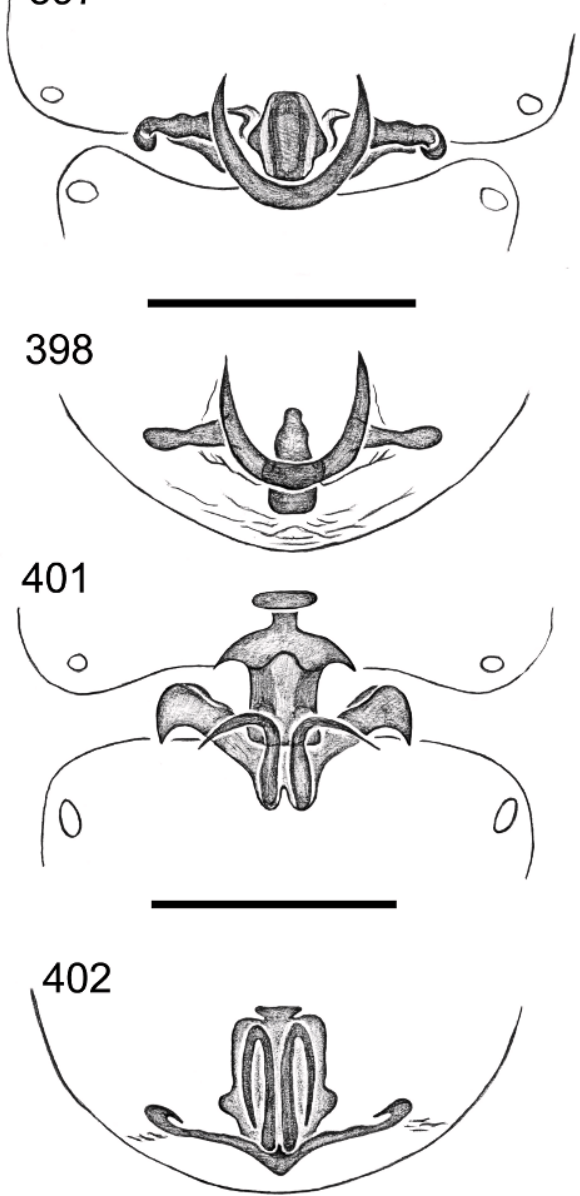

Figs. 391-402. Predatoroonops species, female internal genitalia. 391-396, Predatoroonops peterharlli, n. sp. 391-392, Dorsal view, separated: 391, anterior receptaculum; 392, posterior receptaculum. 393-394, Ventral view, separated: 393, anterior receptaculum; 394, posterior receptaculum. 395, Dorsal view, not separated. 396, Posterior view, not separated. 397-398, P. mctiernani, n. sp.: 397, dorsal view; 398, posterior view. 399-400, . chicano, n. sp.: 399, dorsal view; 400, posterior view. 401-402, $P$. olddemon, n. sp.: 401, dorsal view; 402, posterior view. 

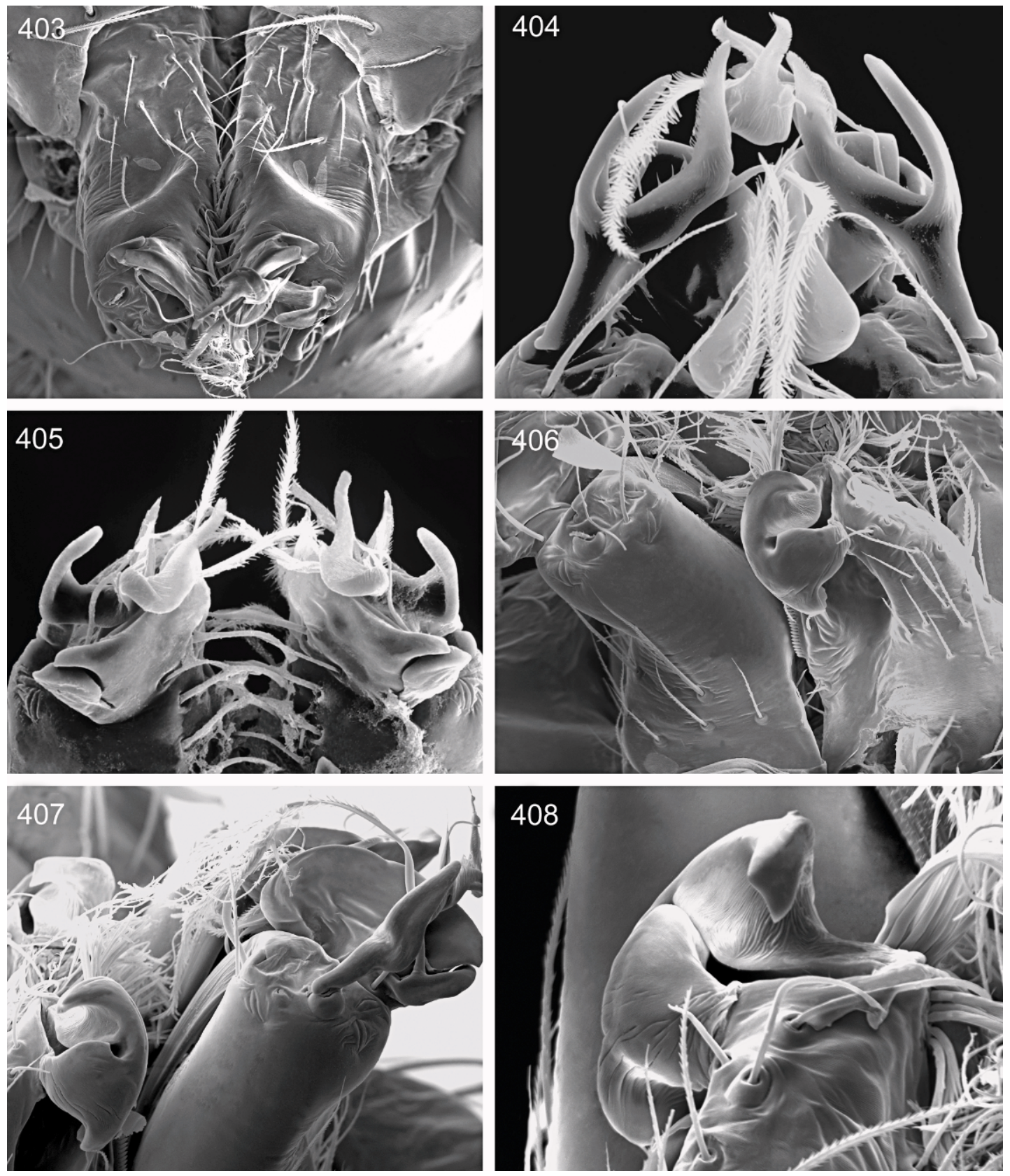

Figs. 403-408. Predatoroonops mctiernani, n. sp., male. 403-405, Chelicerae: 403, frontal view; 404405, ventral view, detail of distal apophysis. 406-407, Chelicerae and endites, distal area, lateral view. 408, Endite, apex, ventral view.

apophysis elongate and flattened with very slender tip; condylar projection absent (fig. 24). Abdomen dorsum white. Legs white, femur I missing. Leg spination: I missing, femur: II d0-1-0; III-IV d0-1-0; tibia II v2-2-2-
2-2, III-IV d1-1-0; p1-1-0; v2-2-0; r1-1-0; metatarsus II v2-2-2-2, III d1-1-0; v2-1-0; r1$0-0$; IV d1-1-0; p1-0-0; v2-1-0; r1-0-0. Male palp proximal segments and cymbium yellow, bulb white, with short and large laminar 

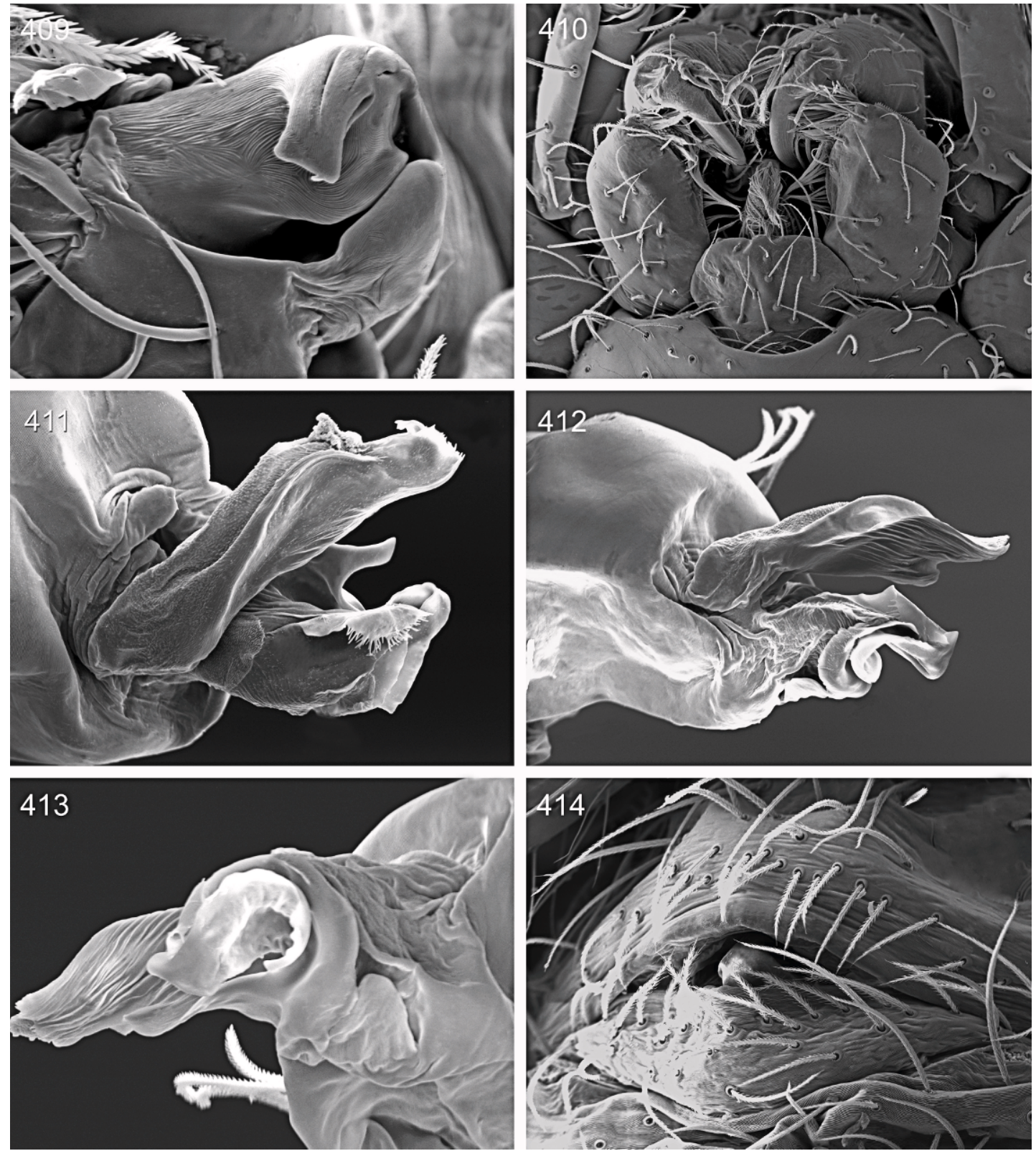

Figs. 409-414. Predatoroonops mctiernani, n. sp. 409, Male, endite, distal area, apical view. 410, Female, mouthparts, ventral view. 411-413, Male, palp, distal process: 411, retrolateral view; 412, dorsal view; 413, prolateral view. 414, Female, epigastric region, ventral view.

hyaline process and enlarged hyaline process with short and slender tip (figs. 340-342).

Female: Unknown.

Other Material ExAmined: None.

DistRIBUTION: Known only from the type locality, in the state of Bahia, Brazil (map 3).
Predatoroonops yautja Brescovit, Rheims, and Santos, new species

Figures 25, 282-283, 343-361; map 3

TYPES: Male holotype and female paratype from RPPN Serra do Caraça, $20^{\circ} 05^{\prime} \mathrm{S}$, 

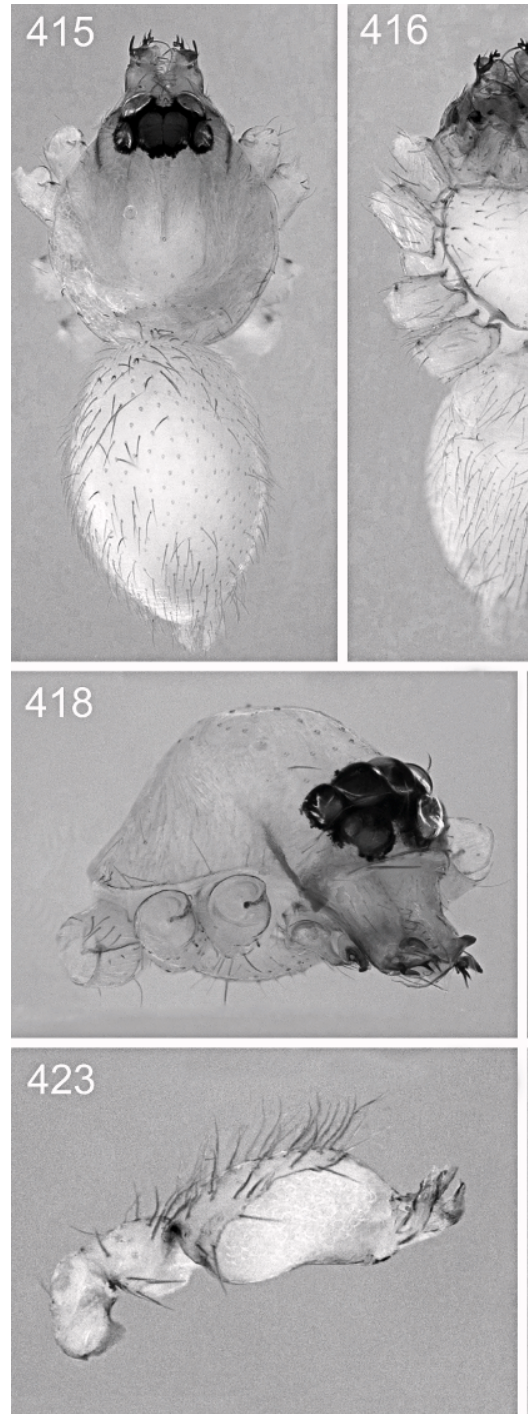
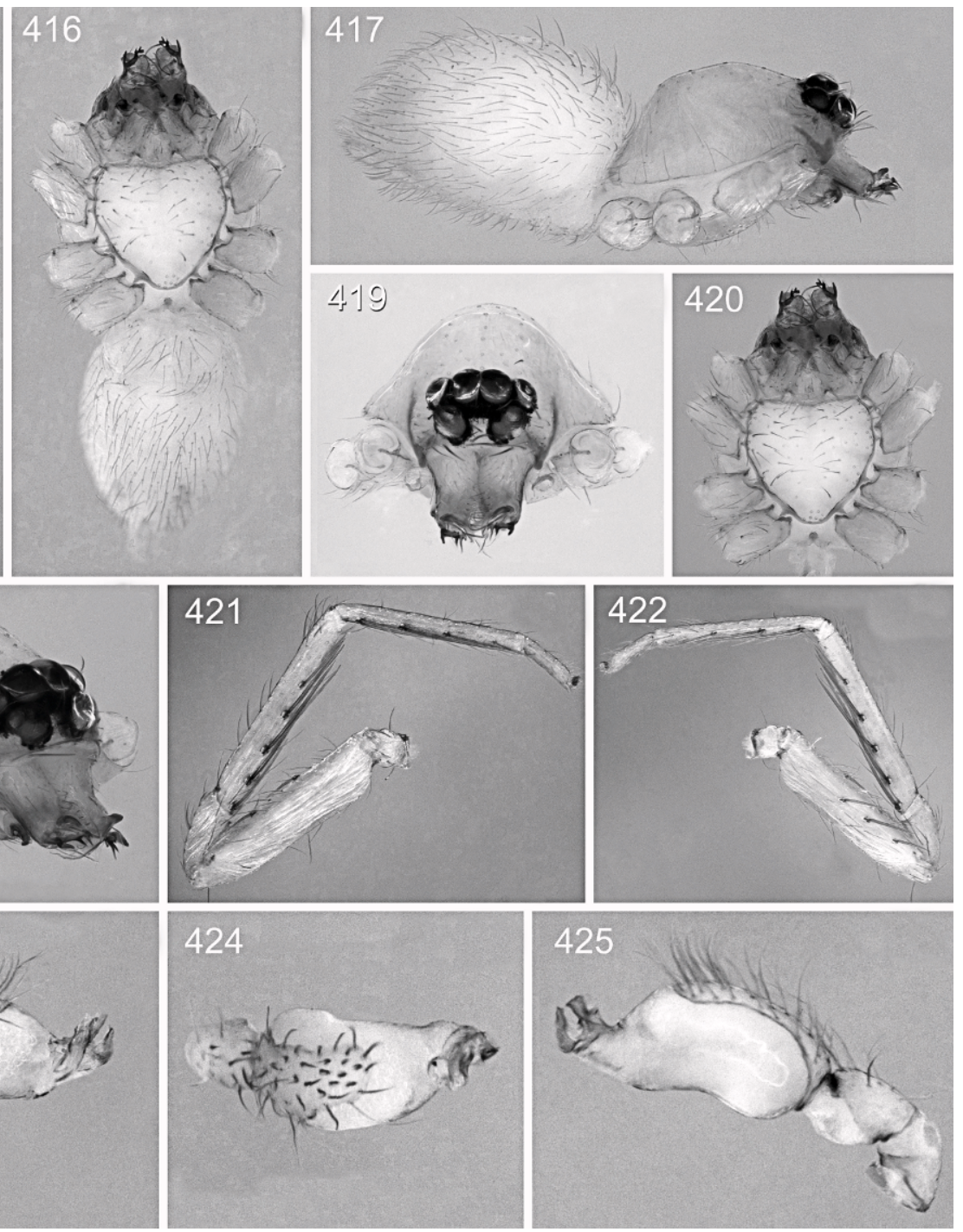

Figs. 415-425. Predatoroonops mctiernani, n. sp., male. 415-417, Body: 415, dorsal view; 416, ventral view; 417, lateral view. 418-420, Carapace: 418, laterofrontal view; 419, frontal view; 420, ventral view. 421-422, Leg I: 421, retrolateral view; 422, prolateral view. 423-425, Palp: 423, retrolateral view; 424, dorsal view; 425, prolateral view.

$43^{\circ} 29^{\prime} \mathrm{W}$, Catas Altas, Minas Gerais, Brazil, pitfall (Apr. 24-May 01, 2002, Equipe Biota) deposited in IBSP 136650 (PBI_OON 11845) and IBSP 136349 (PBI_OON 11847), respectively.

ETYMOLOGY: The specific name is a noun and refers to the fictional name by which Predators are known on their planet. The "yautja" live in a matriarchal clan-based society, with the strongest and most skilled of the group as the leader.

DiAgNosis: Males of Predatoroonops yautja differ from those of the remaining species by the strong setae on the clypeus (fig. 25); subdistal apophysis long and slender, distal apophysis inconspicuous on chelicerae (fig. 25). Females can be easily distinguished from those of the remaining species by the 


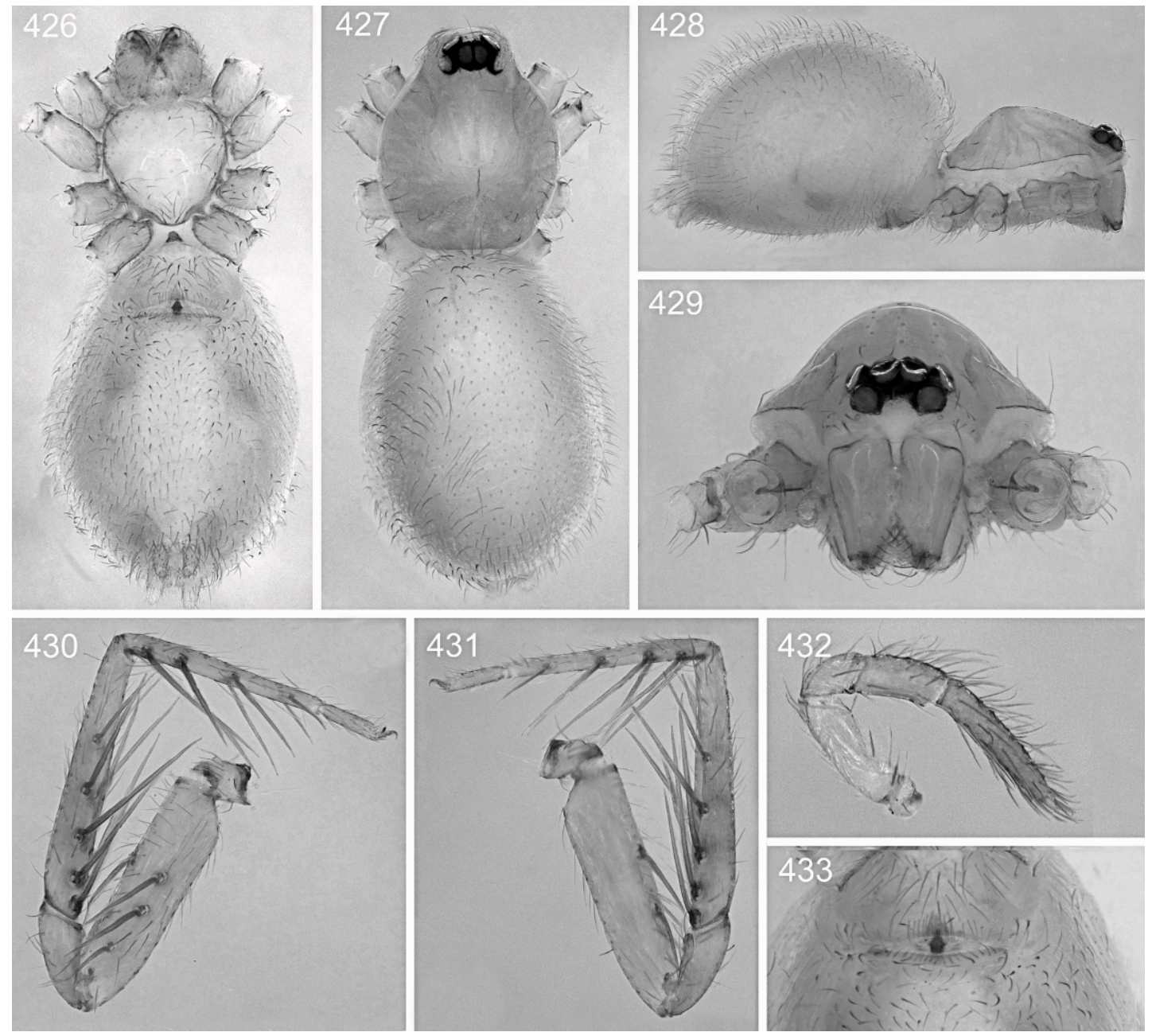

Figs. 426-433. Predatoroonops mctiernani, n. sp., female. 426-428, Body: 426, ventral view; 427, dorsal view; 428, lateral view. 429, Carapace, frontal view. 430-431, Leg I: 430, prolateral view; 431, retrolateral view. 432, Pedipalp, prolateral view. 433, Internal genitalia, ventral view.

anterior receptaculum triangular, sulcated medially, truncated at tip, with the posterior receptaculum oval, nose shaped (fig. 282).

MAle (PBI_OON_11845): Total length 1.92. Carapace 0.90 long, 0.75 wide. ALE 0.10, PLE 0.10, PME 0.12, ALE-ALE 0.06. Carapace pale orange, without any pattern, anterolateral corners without slightly sclerotized triangular projections (figs. 343-344). Sternum, chelicerae, endites, and labium yellow. Clypeus with strong distinct needlelike setae (fig. 25). Chelicerae anterior face without median and subdistal furrow, sub- distal apophysis long and slender, distal apophysis inconspicuous and condylar projection absent (fig. 25). Abdomen dorsum white. Legs yellow, femur I 0.73 long. Leg spination: femur: I d1-0-1; v1-2-2; II d1-0-1; v0-2-2; III-IV d1-0-1; tibia I v2-2-2-2-2, II v2-2-2-2-2, III-IV d0-1-0; p1-1-0; v0-1-2; r1-1-0; metatarsus I v2-22-2, II v2-2-2-2, III d0-1-0; v0-1-2; r1-1-0; IV d0$1-0 ;$ p1-1-0; v0-1-2; r1-1-0. Male palp proximal segments white; cymbium yellow; bulb white, with distal area elongated, laminar hyaline process short, curved, hyaline process short (figs. 350-352). 
Female (PBI_OON_11848): Total length 2.32. Carapace 0.85 long, 0.76 wide. ALE 0.10, PLE 0.10, PME 0.12, ALE-ALE 0.06. Abdomen dorsum pale white. Legs: femur I 0.83 long. Leg spination: femur I d1-0-0; v12-2; II d1-0-0; v0-2-2; III d0-1-1; IV d1-0-1; tibia I v2-2-2-2-2, II v2-2-2-2-2, III d0-1-0; p1-1-0; v0-1-1; r1-1-0; IV d0-1-0; p1-1-0; v0$1-2 ; \mathrm{r} 1-1-0$; metatarsus I v2-2-2-2, II v2-2-2-2, III d0-1-0; v0-1-2; r0-0-1; IV d0-1-0; p0-1-1; $\mathrm{v} 0-1-2 ; \mathrm{r} 0-1-1$. Internal genitalia with anterior receptaculum triangular, sulcated medially and truncated at tip; posterior receptaculum oval, nose shaped ventrally, globose posteriorly; apodema plate short and curved distally, with long transversal and sinuous apodema process (figs. 282-283).

OTHER MATERIAL EXAMINED: BRAZIL: Minas Gerais: Catas Altas, RPPN Serra do Caraça, $20^{\circ} 05^{\prime} \mathrm{S}, 43^{\circ} 29^{\prime} \mathrm{W}$, pitfall, Apr. 24 May 01, 2002 (Equipe Biota; IBSP 136344 136346, PBI_OON 11849; 11132; 11121), 3 § ; (IBSP 136347-136348. PBI_OON 11845, 11848), 1 के 1 우.

DistRIBUTION: Known only from the type locality, in the state of Minas Gerais, Brazil (map 3).

Predatoroonops peterhalli Brescovit, Rheims, and Santos, new species

Figures 3-4, 9, 26, 362-396; map 1

TyPes: Male holotype and female paratype from Condomínio Trensurb, $23^{\circ} 33^{\prime} \mathrm{S}$, $46^{\circ} 55^{\prime} 60^{\prime \prime} \mathrm{W}$, Itapevi, São Paulo, Brazil (Nov. 01, 2000, V. Onofrio and D.M. Battesti) deposited in IBSP 124233 (PBI_OON 11206).

ETYMOLOGY: The specific name is a patronym in honor of the late Kevin Peter Hall (1955-1991), who played the Predator creature in the movie.

Diagnosis: Males of Predatoroonops peterhalli differ from those of the remaining species by the subdistal apophysis long and slender, with flattened and sulcated apex on the chelicerae (fig. 26). Females can be easily distinguished from those of the remaining species by the epigynum with globose posterior receptaculum, apodema plate coiled at base, with a short anterior projection (figs. 395-396).

MALE (PBI_OON_0011206): Total length 1.80. Carapace 0.80 long, 0.55 wide. ALE
0.10, PLE 0.10, PME 0.12, ALE-ALE 0.06. Carapace pale orange, with brown stripe along the margin of pars cephalica, anterolateral corners with slightly sclerotized triangular projections (figs. 371-372). Sternum, chelicerae, endites, and labium yellow. Clypeus with very small needlelike setae (fig. 26). Chelicerae anterior face without median and subdistal furrow, subdistal apophysis long, slender, and sinuous, distal apophysis short; condylar projection absent (fig. 26). Abdomen dorsum white. Legs yellow, femur I 0.65 long. Leg spination: femur: I-II v1-2-2; IIIIV d1-0-1; tibia I v2-2-2-2-2, II v2-2-2-2-2, III d0-1-0; p0-1-1; v0-1-2; r0-0-1, IV d0-1-0; v0-12; r0-1-1; metatarsus I v2-2-2-2, II v2-2-2-2, III d0-0-1; v1-0-2; r1-1-0, IV d0-0-1; p0-1-0; v0-1-2; r1-1-0. Male palp proximal segments yellow; cymbium and bulb yellow, with distal area elongated, with laminar hyaline process and slender hyaline process short, twisted (figs. 364-365, 376-378).

Female (PBI_OON_0011206): Total length 2.10. Carapace 0.85 long, 0.70 wide. ALE 0.12, PLE 0.12, PME 0.14, ALE.ALE 0.06 . Carapace without any pattern. Abdomen dorsum pale white. Legs yellow, femur I 0.70. Leg spination: femur: I, II v1-2-2; III d0-1-1; IV d1-0-1; tibia I v2-2-2-2-2, II v2-22-2-2, III d0-1-0; p0-1-1; v0-0-2; r0-1-1, IV d0-1-0; p0-1-1; v0-1-2; r0-0-1; metatarsus I v2-2-2-2, II v2-2-2-2, III v0-1-2; r0-1-1, IV $\mathrm{d} 0-1-1$; $\mathrm{p} 0-1-1$; $\mathrm{v} 0-1-2$; $\mathrm{r} 0-1-1$. Internal genitalia with large anterior receptaculum and posterior receptaculum globose, with a short anterior projection; apodema plate long, slender, coiled at base, with small, rounded apodema process (figs. 387-390, 394-395).

OTHER MATERIAl EXAMINED: BRAZIL: São Paulo: Itapevi, Condomínio Trensurb, $23^{\circ} 33^{\prime} \mathrm{S}$, 46 $55^{\prime} 60^{\prime \prime} \mathrm{W}$, (IBSP 124235, PBI_OON 11205), 1 ; ; (AMNH, PBI 11608), 1 s 1 웅 (IBSP 160853, PBI_OON 11207), $1 \hat{\delta}$ 2우 (IBSP 160854, PBI_OON 11851), 2 ; ; all collected with pitfall traps in Dec. 2000 by V. Onofrio and D.M. Battesti; São Paulo, Campus IBSP, Horto Oswaldo Cruz, $46^{\circ} 43^{\prime} \mathrm{W}, 2^{\circ} 33^{\prime} \mathrm{S}$ (D.F. Candiani, IBSP 42172-42173, PBI_OON 10978, 10980), 2 đ̊; São Paulo, Campus da USP, Mata do CUASO, 46 $43^{\prime} \mathrm{W}, 2^{\circ} 33^{\prime} \mathrm{S}$, Aug. 16-23, 1999 (IBSP 42183, PBI_OON 10979), 1 s ; (IBSP 42188, PBI_OON 11214), 1 \% ; (IBSP 42152, PBI_OON 11204), 1 s ; (IBSP 42193, PBI_OON 
11061), 1 oิ 2우 (IBSP 42174, PBI_OON 11064), $1 \hat{\delta}$; (IBSP 42195, PBI_OON 11062), 1 ᄒٔ; (IBSP 59270, PBI_OON 11065), $1 \delta$; (IBSP 66859, PBI_OON 11063), $1 \hat{\delta}$; all collected with pitfalls by D.F. Candiani; São Paulo, Parque Burle Marx, $23^{\circ} 35^{\prime} \mathrm{S}, 46^{\circ} 39^{\prime} \mathrm{W}$, pitfall, Mar. 18-23, 2005 (A. Bagio, IBSP 59271, PBI_OON 11208), 1 \% ; São Paulo, Parque Estadual do Jaraguá, $23^{\circ}$ $27^{\prime} 33^{\prime \prime} \mathrm{S}, 46^{\circ} 46^{\prime}$ 02"W (IBSP 136557-136563, PBI_OON 11038-11143), 2 के 5우 (IBSP 136565, PBI_OON 11145), 1亏; (IBSP 136567; PBI_OON 11142), 1 \% , all collected wit pitfalls by Equipe Biota; Santo André, Reserva Biológica de Paranapiacaba, $23^{\circ} 46^{\prime} 00^{\prime \prime}-23^{\circ} 47^{\prime} 10^{\prime \prime} \mathrm{S}$, $46^{\circ} 18^{\prime} 20^{\prime \prime}-46^{\circ} 20^{\prime \prime} 40^{\prime \prime} \mathrm{W}$, pitfall, May 17, 2007 (M. Uehara-Prado, IBSP 91423, PBI_OON 11209), $1 \delta$; São José do Barreiro, Parque Nacional da Serra da Bocaina, $22^{\circ} 38 \mathrm{~S}, 44^{\circ} 34^{\prime} \mathrm{W}$, pitfall, Apr.28-May 03, 2002 (Equipe Biota, IBSP 68550, PBI_OON 11210), 1 tิ 1 웅 Salesópolis, Estação Ecológica de Boracéia, $23^{\circ} 39^{\prime} 08.3^{\prime \prime} \mathrm{S}$, $45^{\circ} 53^{\prime} 48.9^{\prime \prime} \mathrm{W}$, pitfalls, May 18-24, 2001, (IBSP 91410-91412, PBI_OON 11211, 11213, 11187; IBSP 91414, PBI_OON 11188; IBSP 9417, PBI_OON 11212; IBSP 136487-136500, PBI_ OON 11189-11192), 4 $\hat{\sigma} 5$ 우, all collected by $\mathrm{M}$. Uehara-Prado; Caucaia do Alto, Reserva do Morro Grande, $23^{\circ} 39^{\prime}-23^{\circ} 48^{\prime} \mathrm{S}, 47^{\circ} 01^{\prime}-46^{\circ} 55^{\prime} \mathrm{W}$, pitfall, Mar. 7-27, 2003 (IBSP 136568-136577, PBI_OON 11133-11139, 11146-11148), 10 के, all collected by Equipe Biota.

DistRIBUTION: Known only from the state of São Paulo, Brazil (map 1).

\section{Predatoroonops mctiernani Brescovit,}

Rheims, and Santos, new species

Figures 1, 10, 27, 397-398, 403-433; map 4

TYPES: Male holotype and female paratype from Fazenda Santa Helena, 22 $34^{\prime}$ S, $44^{\circ} 21^{\prime} \mathrm{W}$, Pinheiral, Rio de Janeiro, Brazil (Nov. 5-11, 1999, A.D. Brescovit et al.), deposited in IBSP 66861 (PBI_OON 10919) and IBSP 66875 (PBI_OON 10920), respectively.

ETYMOLOGY: The specific name is a patronym in honor of John McTiernan, the director of the first movie in the "Predator" series.

DiAgnosis: Males of Predatoroonops mctiernani differ from those of the remaining species by the subdistal apophysis short and distal apophysis with three branches on chelicerae (figs. 27, 403-405). Females can be easily distinguished from those of the remaining species by the epigynum with fused anterior and posterior receptacula, apodema process with curved extremities (figs. 397-398).

Male (PBI_OON 10919): Total length 1.69. Carapace 0.83 long, 0.64 wide. ALE 0.10, PLE 0.10, PME 0.12, ALE-ALE 0.06. Carapace yellow, without any pattern, anterolateral corners with sclerotized triangular projections (figs. 417-419). Sternum, chelicerae, endites, and labium yellow. Clypeus with very small needlelike setae (fig. 27). Chelicerae anterior face without median and subdistal furrow, subdistal apophysis short, distal apophysis long with three branches; condylar projection absent (figs. 27, 403405). Abdomen dorsum white. Legs yellow, femur I 0.65 long. Leg spination: femur I v22-2; II v0-2-2; III d1-0-1; IV d1-0-0; tibia I v22-2-2-2, II v2-2-2-2-2, III d1-0-0; v0-0-2, IV p1-0-1; v0-1-1, metatarsus I v2-2-2-2, II v2-22-2, III v0-0-2; IV p0-0-1; v0-0-2. Male palp proximal segments and cymbium yellow, bulb white, distal area elongated, with long, flattened laminar process, hyaline process slender, sinuous (figs. 411-413, 423-425).

Female (PBI_OON 10920): Total length 2.10. Carapace 0.85 long, 0.75 wide. ALE 0.10, PLE 0.10, PME 0.12, ALE.ALE 0.08. Carapace pale orange. Chelicerae fang with rounded median process. Abdomen dorsum with gray pattern. Legs pale orange, femur I 0.74 long. Leg spination: femur: I-II v2-2-2; III d1-0-1; IV d1-0-0; tibia I v2-2-2-2-2, II v22-2-2-2, III v0-0-2, IV p1-0-1; v0-1-1, metatarsus I v2-2-2-2, II v2-2-2-2, III v0-0-2; IV p1-0-1; v0-0-2. Internal genitalia with fused anterior and posterior receptacula; apodema plate semicircular and flattened, and with long apodema process, which is curved at tip (figs. 397-398).

OTHER MATERIAL EXAMINED: BRAZIL: Rio de Janeiro: Pinheiral, Fazenda Regional de Criação/Fazenda Santa Helena, 22 34'S, 44 $21^{\prime} \mathrm{W}$ (Nov. 05-11, 1999, A.D. Brescovit et al. (IBSP 66879, PBI_OON 11014, $1 \hat{\delta}$; (IBSP 66888, PBI_OON 11012), $1 \hat{\delta}$; (IBSP 66883, PBI_OON 11013), 1 क ; (IBSP 66892, PBI_OON 11010), $1 \hat{\delta}$; (IBSP 66885, PBI_OON 11016), 1 sे; (IBSP 66889, PBI_OON 11019), 1 ; ; (IBSP 66876, PBI_OON 10977), 1 \%; (IBSP 66887, $66867,66882,66865$, respectively PBI_OON 11025-11028), 2 क 2 웅, used for SEM); Fazenda Santa Helena, $22^{\circ} 34^{\prime} \mathrm{S} 44^{\circ} 21^{\prime} \mathrm{W}$, Nov. 05-11, 




Map 4. Distribution of four new Predatoroonops species in southeastern and eastern Brazil: Predatoroonops mctiernani, P. maceliot, P. vallarta, and P. poncho.

1999 (A.D. Brescovit et al. (IBSP 66874, PBI_OON 11011), $1 \hat{\delta}$; (IBSP 66873, PBI_OON 11017), 1 $\hat{\delta}$; (IBSP 66871, PBI OON 11018), $1 \hat{\delta} ;$ (IBSP 66866, PBI_OON 11015), $1 \hat{\delta}$; (IBSP 66863, PBI_OON 11022), $1 \hat{\delta}$, (IBSP 66860, PBI_OON 10976), 1 के; (IBSP 66872, PBI_OON 11117), $1 \hat{\delta}$, used for SEM. Teresópolis, Parque Nacional da Serra dos Orgãos, $22^{\circ} 27^{\prime} \mathrm{S}$ 42 59'W, Aug. 23, 2001 (Equipe Biota, IBSP 135892-135895, PBI_OON 11080-11083), 4ð̊; São Paulo: São Bernardo do Campo, Parque Estoril, $23^{\circ} 41^{\prime} \mathrm{S}, 46^{\circ} 32^{\prime} \mathrm{W}$, Jun. 26-Jul. 02, 2007 (C.V. Janini, (IBSP 119570, 119685 119687, 119689, PBI_OON 11073-11074, 11085-11088), 5ð 2+; São Paulo, campus da USP, Mata do CUASO, $46^{\circ} 43^{\prime} \mathrm{W}$, 233' S, Nov. 16-23, 1999 (D.F. Candiani, IBSP 42187, PBI_OON 11072), 2 ô 1 \% ; Santa Catarina: Blumenau, Parque Nascentes do Rio Garcia, $27^{\circ} 01^{\prime} \mathrm{S}-49^{\circ} 09^{\prime} \mathrm{W}$, Jan. 21-28, 2003 (Equipe Biota, IBSP 136070, PBI_OON 11084), 1 오.

Distribution: Known from the states of Rio de Janeiro, São Paulo, and Santa Catarina, Brazil (map 4).
Predatoroonops chicano Brescovit, Rheims, and Santos, new species

Figures 28, 399-400, 434 452; map 3

TyPES: Male holotype and female paratype from Reserva Florestal da Companhia Vale do Rio Doce, $19^{\circ} 06^{\prime} \mathrm{S}-19^{\circ} 18^{\prime} \mathrm{S}, 39^{\circ} 45^{\prime} \mathrm{W}-$ $40^{\circ} 19^{\prime} \mathrm{W}$, Linhares, Espírito Santo, Brazil (Jun. 1997, J. Raizer), deposited in IBSP 14877 (PBI_OON 10985) and IBSP 14858 (PBI_OON 10987), respectively.

ETYMOLOGY: The specific name is a second nickname for the character Jorge "Poncho" Ramirez, played by Richard Chaves in the movie "Predator"; Poncho is a Mexican-American who initially serves a translator for Anna.

Diagnosis: Males of Predatoroonops chicano differ from those of the remaining species by the very large and quadrate projection in the middle face of the chelicerae (fig. 28). Females can be easily distinguished from those of the remaining species by the peanut-shaped anterior and posterior receptacula, apodema process sinuous, pointed anteriorly (figs. 399-400, 452). 

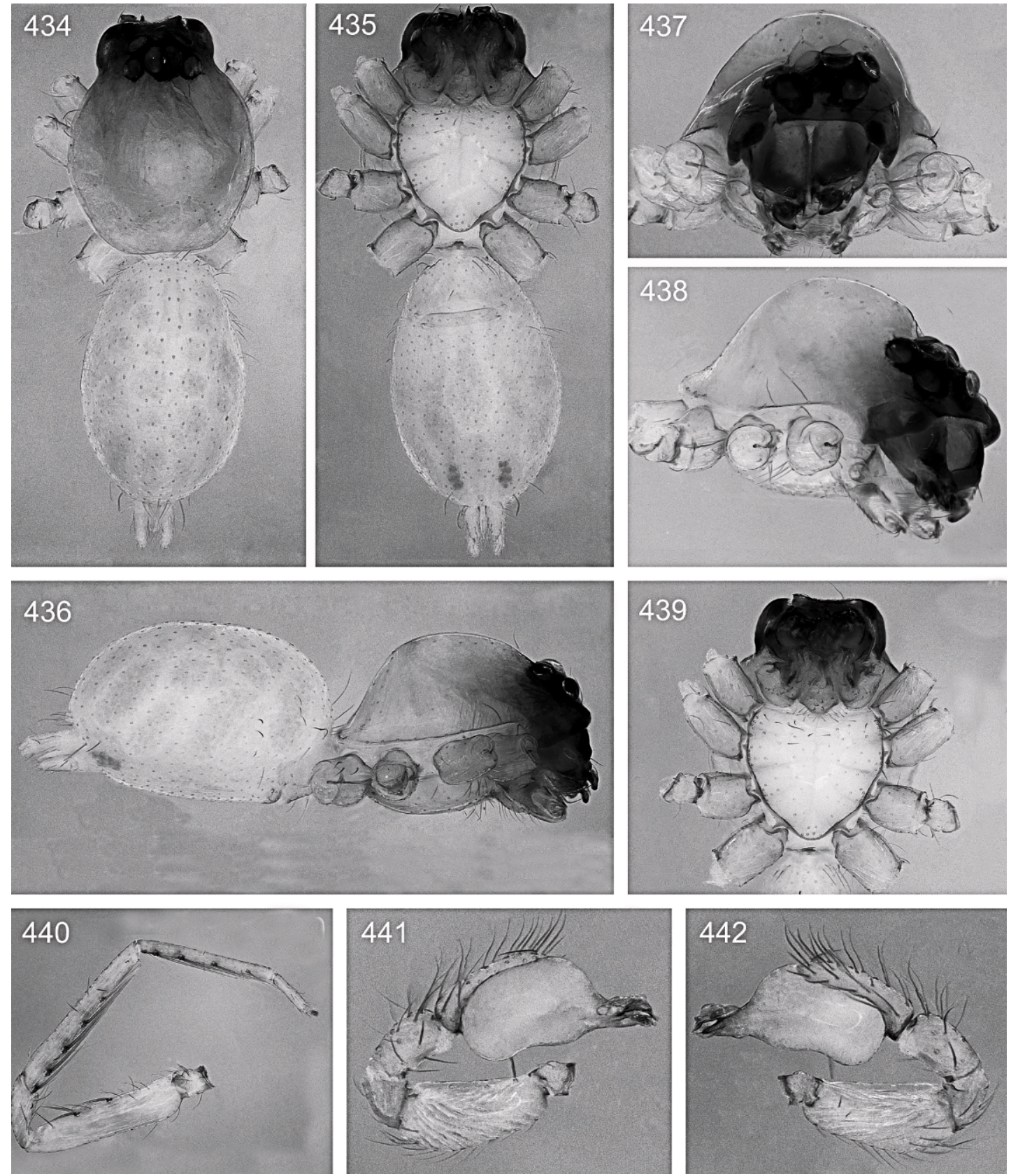

Figs. 434 442. Predatoroonops chicano, n. sp., male. 434-436, Body: 434, dorsal view; 435, ventral view; 436, lateral view. 437-439, Carapace: 437, frontal view; 438, lateral view; 439, ventral view. 440, Leg I, retrolateral view. 441-442, Palp: 441, retrolateral view; 442, prolateral view.

MALE (PBI_OON 10985): Total length 1.05. Carapace 0.82 long, 0.65 wide. ALE 0.10 , PLE 0.08, PME 0.12, ALE-ALE 0.08. Carapace pale orange, with brown stripe along margin of cephalic area, anterolateral corners with sclerotized triangular projections (figs. 437-438). Chelicerae brown. Sternum, endites, and labium yellow. Clypeus 

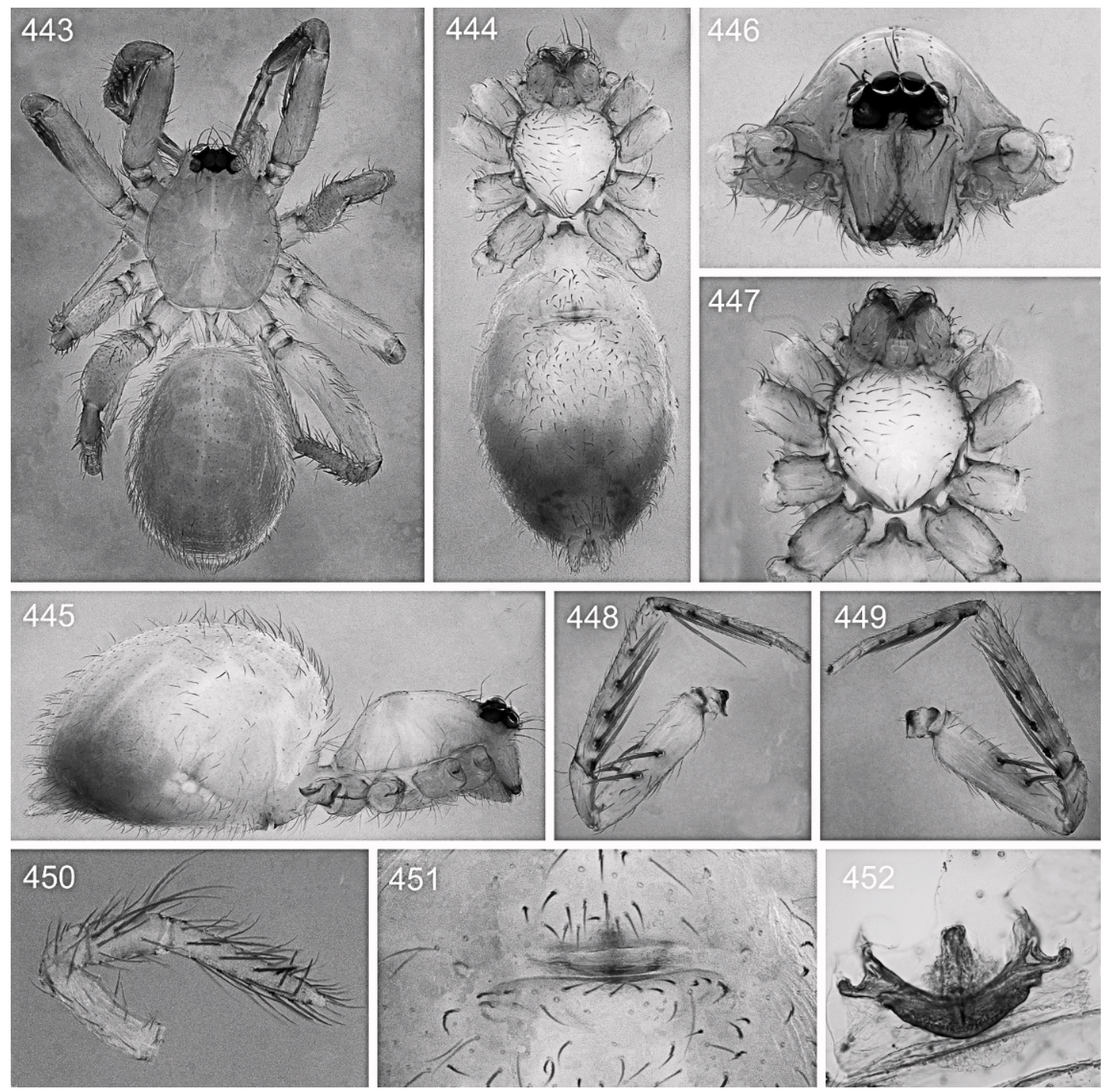

Figs. 443-452. Predatoroonops chicano, n. sp., female. 443-445, Body: 443, dorsal view; 444, ventral view; 445, lateral view. 446-447, Carapace: 446, frontal view; 447, ventral view. 448-449, Leg I: 448, prolateral view; 449, retrolateral view. 450, Pedipalp, prolateral view. 451-452, Internal genitalia: 451, ventral view; 452, dorsal view.

with very small needlelike setae (fig. 28). Chelicerae anterior face without median and subdistal furrow, with very large and quadrate apophysis in the middle of the face; distal apophysis absent, subdistal apophysis short, condylar projection absent (fig. 28). Abdomen dorsum pale white. Legs yellow, femur I 0.60. Leg spination: femur I v1-2-2, II v0-2-1, III-IV d1-0-0; tibia I v2-2-2-2-2, II v2-2-2-2-2, III d0-1-1; p0-0-1, IV d0-1-0; p11-0; v1-0-1; r1-1-0, metatarsus I v2-2-2-2, II v2-2-2-2, III v0-0-1; r0-0-1, IV d0-0-2; p0-0-1; r0-0-1. Male palp proximal segments and cymbium yellow, bulb white, short laminar process, slender hyaline process (figs. 441442).

Female (PBI_OON 10987). Total length 1.05. Carapace 0.90 long, 0.60 wide. ALE 

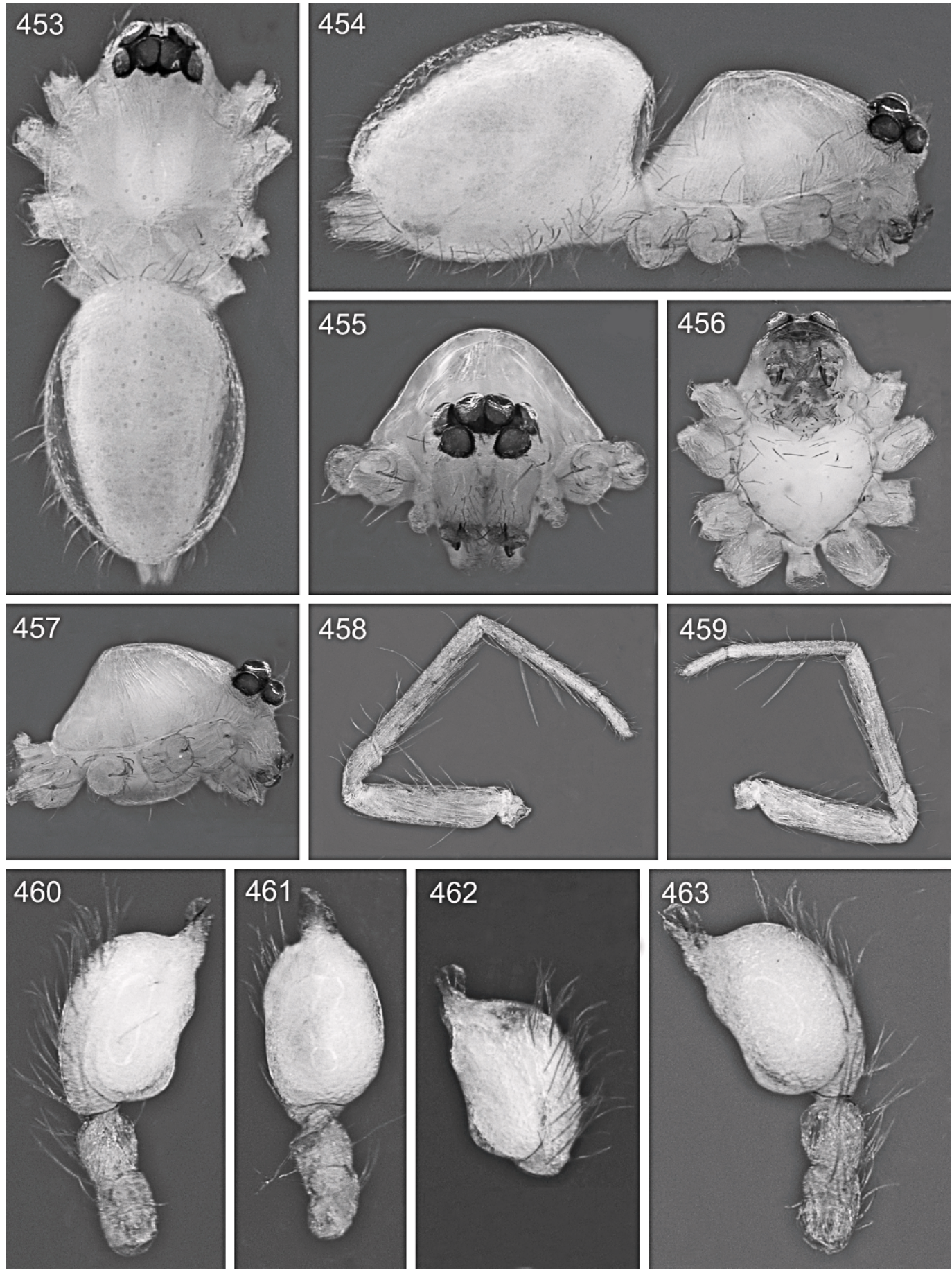

Figs. 453-463. Predatoroonops olddemon, n. sp., male. 453-454, Body: 453, dorsal view; 454, lateral view. 455-457, Carapace: 455, frontal view; 456, ventral view; 457, lateral view. 458-459, Leg I: 458, retrolateral view; 459, prolateral view. 460-463, Palp: 460, retrolateral view; 461, ventral view; 462, ventrodistal view; 463, prolateral view. 



Figs. 464 474. Predatoroonops olddemon, n. sp., female. 464-465, Body: 464, dorsal view; 465, lateral view. 466-468, Carapace: 466, frontal view; 467, lateral view; 468, ventral view. 469, Abdomen, ventral view. 470-471, Leg I: 470, prolateral view; 471, retrolateral view. 472-473, Pedipalp: 472, prolateral view; 473, retrolateral view. 474, Internal genitalia, ventral view.

0.10, PLE 0.08, PME 0.11, ALE-ALE 0.08. Abdomen dorsum pale orange, without color pattern. Legs: femur I 0.70. Leg spination: femur I-II v0-2-2; III d1-0-0; tibia I v2-2-2-22 , II v2-2-2-2-2, III p0-1-1; v0-1-2; r0-0-1; IV d0-1-0; p1-0-0; v1-0-0; r0-1-1; metatarsus I v2-2-2-2, II v2-2-2-2, III v0-1-2; r0-0-1; IV d0-1$1 ; \mathrm{p} 1-1-0 ; \mathrm{v} 0-1-1 ; \mathrm{r} 1-1-0$. Internal genitalia peanut shaped, with fused anterior and posterior receptacula; apodema plate semicircular, slender with apodema process long, sinuous, pointed anteriorly (figs. 399-400, 452). 
OTHER MATERIAl ExAmined: BRAZIL: Espírito Santo: Linhares, Reserva Florestal da Companhia Vale do Rio Doce, $19^{\circ} 06^{\prime} \mathrm{S}-$ $19^{\circ} 18^{\prime} \mathrm{S}, 39^{\circ} 45^{\prime} \mathrm{W}-40^{\circ} 19^{\prime} \mathrm{W}$, Jun. 01, 1997 (J. Raizer, IBSP 14866, PBI_OON 10986), 1 \% Jul. 01, 1998 (G. Machado and A.J. Santos, IBSP 27004, PBI_OON 11040), 1 영 Jun. 01, 1997 (J. Raizer, IBSP 14862, PBI_OON 11041), 1 ㅇ.

DistRIBUTION: Known only from the type locality, in the state of Espírito Santo, Brazil (map 3).

Predatoroonops olddemon Brescovit, Rheims, and Santos, new species

Figures 29, 401-402, 453-474; map 1

TYPES: Male holotype and female paratype from Fazenda Maravilha, $22^{\circ} 12^{\prime} \mathrm{S}-$ $43^{\circ} 16^{\prime} \mathrm{W}$, Paraíba do Sul, Rio de Janeiro, Brazil (Aug. 16-18, 2001, Equipe Biota) deposited in IBSP 136643 (PBI_OON 11036) and IBSP 136645 (PBI_OON 11034), respectively.

ETYMOLOGY: The specific name is a popular name used by natives of the fictional nation of Val Verde for the Predators; during the hot summers these creatures attack people, who are later found skinned and hollowed.

Diagnosis: Males of Predatoroonops olddemon differ from those of the remaining species by the simple, dorsally curved subdistal apophysis, curved, longer and slender distal apophysis in the chelicerae (fig. 29). Females can be easily distinguished from those of the other species by the epigynum with distal process mushroom shaped, with massive, rectangular posterior receptaculum (figs. 401-402).

Male (PBI_OON_11036): Total length 1.70. Carapace 0.75 long, 0.55 wide. ALE 0.08, PLE 0.08, PME 0.10, ALE-ALE 0.06. Carapace yellow, without any pattern, anterolateral corners without extension or projections (figs. 454 455, 457). Sternum, chelicerae, endites, and labium yellow. Clypeus with distinct needlelike setae (fig. 29). Chelicerae anterior face without median and subdistal furrow, with upward-curving subdistal apophysis, distal apophysis curved, longer and slender, condylar projection absent (fig. 29). Abdomen dorsum white.
Legs yellow, femur I 0.60. Leg spination: femora I-II d1-1-0; v0-2-2; III-IV d1-1-0; tibia I v2-2-2-2-2, II v2-2-2-2-2, III p1-1-0; v1-0-1; r1-1-0; IV p1-0-0; v1-0-0; r1-1-0; metatarsus I v2-2-2-2, II v2-2-2-2, III v0-01; r0-0-1; IV p0-1-1; v0-0-2; r0-0-1. Male palp proximal segments white; cymbium yellow; bulb white, with distal area elongated, laminar with slender hyaline process narrow and short (figs. 460-463).

Female (PBI_OON_11034): Total length 1.90. Carapace 0.80 long, 0.70 wide. ALE 0.10, PLE 0.10, PME 0.12, ALE-ALE 0.08. Abdomen dorsum pale white. Legs: femur I 0.71. Leg spination: femora I-II v0-2-2; III d1-0-1; IV d1-0-0; tibia I v2-2-2-2-2, II v2-22-2-2, III d0-1-0; p1-0-0; v0-1-2; r1-0-0, IV d0-1-0; p1-1-0; v0-1-0; r1-1-0; metatarsus I v2-2-2-2, II v2-2-2-2, III v0-1-1; r1-1-1, IV p1-1-0; v0-1-2; r1-1-0. Internal genitalia with flattened anterior receptaculum with distal process mushroom like and massive rectangular posterior receptaculum; apodema plate with flattened, curved tip and long and curved medially disposed apodema process (figs. 401-402).

OTHER MATERIAL EXAMINED: BRAZIL: Rio de Janeiro: Paraíba do Sul, Fazenda Maravilha, $22^{\circ} 12^{\prime} \mathrm{S}-43^{\circ} 16^{\prime} \mathrm{W}$, pitfall, Aug. 16-18, 2001 (Equipe Biota, IBSP 136646, PBI_OON 11035), 1 ㅇ․

Distribution: Known only from the type locality, in the state of Rio de Janeiro, Brazil (map 1).

\section{ACKNOWLEDGMENTS}

This study was financed in part by U.S. National Science Foundation grant no. 0613754 for a Planetary Biodiversity Inventory of the spider family Oonopidae. The authors would like to thank B. Baher, D. Ubick, and N.I. Platnick and the editors for their critical comments on the manuscript. This study was supported by Conselho Nacional do Desenvolvimento Científico e Tecnológico (CNPq Grant \#301776/2004-0 to A.D.B.; \#307463/2009-5 to A.B.B. and $300498 / 2009-8$ to A.J.S.) and Fapesp (Grant \# 2011/50689-0 to A.D.B.). The third author thanks CNPq for supporting the project "Revisão de gêneros neotropicais das Subfamílias Oonopinae e Gamasomorphinae, no contexto do Inventário Planetário da 
Biodiversidade da Família Oonopidae (Araneae, Dysderoidea)" (Universal-Faixa C, \#478667/2008-6). The fourth author thanks Instituto Nacional de Ciência e Tecnologia dos Hymenoptera Parasitóides da Região Sudeste Brasileira.

\section{REFERENCES}

Álvarez-Padilla, F., and G. Hormiga. 2008. A protocol for digesting internal soft tissues and mounting spiders for scanning electron microscopy. Journal of Arachnology 35: 538-542.

Baehr, B.C., and D. Ubick. 2010. A review of the Asian goblin spider genus Camptoscaphiella (Araneae: Oonopidae). American Museum Novitates 3697: 1-65.

Baher, A.C., M.S. Harvey, and H.M. Smith. 2010. The goblin spiders of the new endemic Australian genus Cavisternum (Araneae: Oonopidae). American Museum Novitates 3684: 1-40.

Bonaldo, A.B., and S.C. Dias. 2010. A structured inventory of spiders (Arachnida, Araneae) in natural and artificial forests gaps at Porto Urucu, western Brazilian Amazonia. Acta Amazonica 40: 357-372.

Bonaldo, A.B., et al. (2009a). Inventário e História Natural dos Aracnídeos da Floresta Nacional de Caxiuanã, Pará, Brasil. In P.L.B. Lisboa (editor), Caxiuanã: desafios para a conservação de uma Floresta Nacional da Amazônia, 545-588. Belém, Brazil: Museu Paraense Emílio Goeldi.

Bonaldo, A.B., A.D. Brescovit, H. Höfer, T. Gasnier, and A.A. Lise. 2009b. A araneofauna (Arachnida, Araneae) da Reserva Florestal Ducke. In C.R.V. da Fonseca, C. Magalhães, J.A. Rafael, and E. Franklin (editors), A fauna de artrópodes da Reserva Florestal Ducke: estado atual do conhecimento taxonômico e biológico, 201-222. Manaus, Brazil: Editora INPA.

Burger, M. 2009. Female genitalia of goblin spiders (Arachnida: Araneae: Oonopidae): a morphological study with functional implications. Invertebrate Biology 128: 340-358.

Burger, M. 2010a. Complex female genitalia indicate sperm dumping in armored goblin spiders (Arachnida, Araneae, Oonopidae). Zoology 113: 19-32.

Burger, M. 2010b. Goblin spiders without distinct receptacula seminis (Arachnida: Araneae: Oonopidae). Journal of Morphology 271: 1110-1118.

Fannes, W. 2010. On Melchisedec, a new genus of the spider family Oonopidae (Araneae, Dysderoidea). American Museum Novitates 3702: 1-28.

Fannes, W., and R. Jocqué. 2008. Ultrastructure of Antoonops, a new, ant-mimicking genus of Afrotropical Oonopidae (Araneae) with complex internal genitalia. American Museum Novitates 3614: 1-30.

Grismado, C.J. 2010. Description of Birabenella, a new genus of goblin spiders from Argentina and Chile (Araneae: Oonopidae). American Museum Novitates 3693: 1-21.

Platnick, N.I. 2011. The world spider catalog, version 11.5. New York: American Museum of Natural History, Available online (http:// research.amnh.org/iz/spiders/catalog). doi: 10.5531/ db.iz.0001.

Platnick, N.I., and N. Dupérré. 2009a. The goblin spider genera Opopaea and Epectris (Araneae, Oonopidae) in the New World. American Museum Novitates 3649: 1-43.

Platnick, N.I., and N. Dupérré. 2009b. The American goblin spiders of the new genus Escaphiella (Araneae, Oonopidae). Bulletin of the American Museum of Natural History 328: 1-151.

Platnick, N.I., and N. Dupérré. 2010. The goblin spider genera Stenoonops and Australoonops (Araneae, Oonopidae), with notes on related taxa. Bulletin of the American Museum of Natural History 340: 1-111.

Saaristo, M.I. 2001. Dwarf hunting spiders or Oonopidae (Arachnida, Araneae) of the Seychelles. Insect Systematics and Evolution 32: 307-358.

Saaristo, M.I., and A. van Harten. 2002. The oonopid spiders (Arachnida: Araneae: Oonopidae) of Socotra, Yemen. Fauna of Arabia 19: 311-319.

Ubick, D. 2005. Oonopidae. In D. Ubick, P. Paquin, P.E. Cushing, and V. Roth (editors), Spiders of North America: an identification manual, 185-188. Keene, NH: American Arachnological Society. 